\begin{tabular}{|c|c|c|c|}
\hline \multirow{2}{*}{\multicolumn{2}{|c|}{ ENGINEERING CHANGE NOTICE }} & & 1. ECN $\quad 654987$ \\
\hline & & Page 1 of $z$ & $\begin{array}{l}\text { Proj. } \\
\text { ECN }\end{array}$ \\
\hline
\end{tabular}

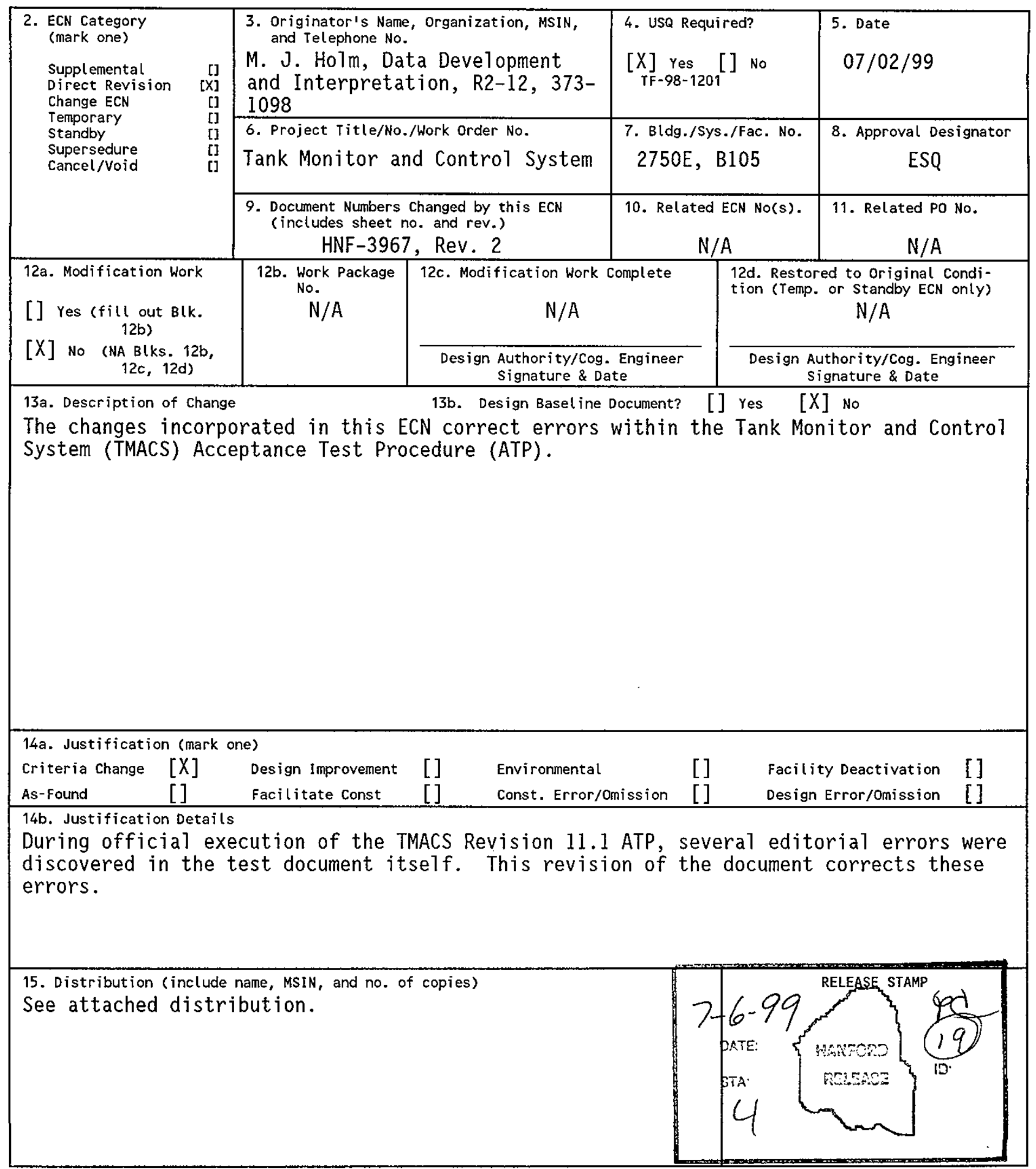




\begin{tabular}{|c|c|}
\hline $\begin{array}{l}\text { 16. Design } \\
\text { Verification } \\
\text { Required } \\
{[] \text { Yes }} \\
{[X] \text { No }}\end{array}$ & $\begin{array}{l}\text { Additiona } \\
\text { Savings }\end{array}$ \\
\hline \multicolumn{2}{|c|}{$\begin{array}{l}\text { 19. Change Impact Re } \\
\text { that will be aff } \\
\text { SDD/DD }\end{array}$} \\
\hline \multicolumn{2}{|c|}{ Functional Design Criteria } \\
\hline \multicolumn{2}{|l|}{ Operating Specification } \\
\hline \multicolumn{2}{|l|}{ Criticality Specification } \\
\hline \multicolumn{2}{|c|}{ Conceptual Design Report } \\
\hline \multicolumn{2}{|l|}{ Equipment Spec. } \\
\hline \multicolumn{2}{|l|}{ Const. Spec. } \\
\hline \multicolumn{2}{|l|}{ Procurement Spec. } \\
\hline \multicolumn{2}{|l|}{ Vendor Information } \\
\hline \multicolumn{2}{|l|}{ OM Manual } \\
\hline \multicolumn{2}{|l|}{ FSAR/SAR } \\
\hline \multicolumn{2}{|l|}{ Safety Equipment List } \\
\hline \multicolumn{2}{|l|}{ Radiation Work Permit } \\
\hline \multicolumn{2}{|c|}{ Environmental Impact Statement } \\
\hline \multicolumn{2}{|l|}{ Environmental Report } \\
\hline Environmental Permit & \\
\hline
\end{tabular}

ENGINEERING

Required

[] Yes
CONSTRUCTION

$\begin{array}{lll}\text { Additional } & {[]} & \$ \\ \text { Savings } & {[]} & \$\end{array}$

18. Schedule Impact (days)

Improvement

Delay
[] []

Indicate the related documents (other than the engineering documents identified on Side 1) change described in Block 13. Enter the affected document number in Block 20.

[] Seismic/Stress Analysis

[] Stress/Design Report

[] interface Control Drawing

[] Calibration Procedure

[] installation Procedure

[] Maintenance Procedure

[] Engineering Procedure

[] Operating Instruction

[]

[]

[]

[]

[]

[]

[]

[]

Inspection Plan
[]

[]

[]

[]

[]

[]

[]

[]

[]

[]

[]

[]

[]

[]

[]
[]

Health Physics Procedure

Spares Multiple Unit Listing

Test Procedures/Specification

Component Index

ASME Coded Item

Human Factor Consideration

Computer Software

Electric Circuit Schedule

ICRS Procedure

Process Control Manual/Plan

Process Flow Chart

Purchase Requisition

Tickler File

Inventory Adjustment Request

\section{[]}

20. Other Affected Documents: (NOTE: Documents listed below will not be revised by this ECN.) Signatures below indicate that the signing organization has been notified of other affected documents listed below. Document Number/Revision Document Number/Revision Document Number Revision N/A

21. Approvals

\section{signature}

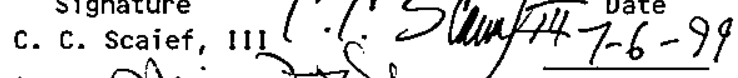

Design Authority Oluisionslol

Cog. Eng. M. J. Holm

Cog. Mgr. K. M. Hall etim Les ffei for $K M H$

QA J. S. Sparks

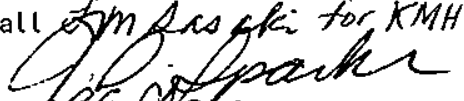

Safety

Environ. P. C. Miller

other R. P. Tucker

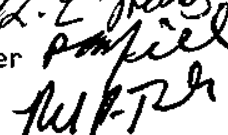

D. A. Selle

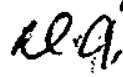

1018

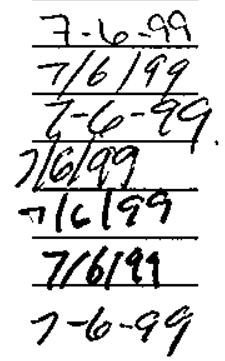

signature

Date

Design Agent

PE

QA

Safety

Design

Envīron.

other

DEPARTMENT OF ENERGY

Signature or a Control Number that

tracks the Approval Signature

ADDITIONAL 


\section{DISTRIBUTION SHEET}

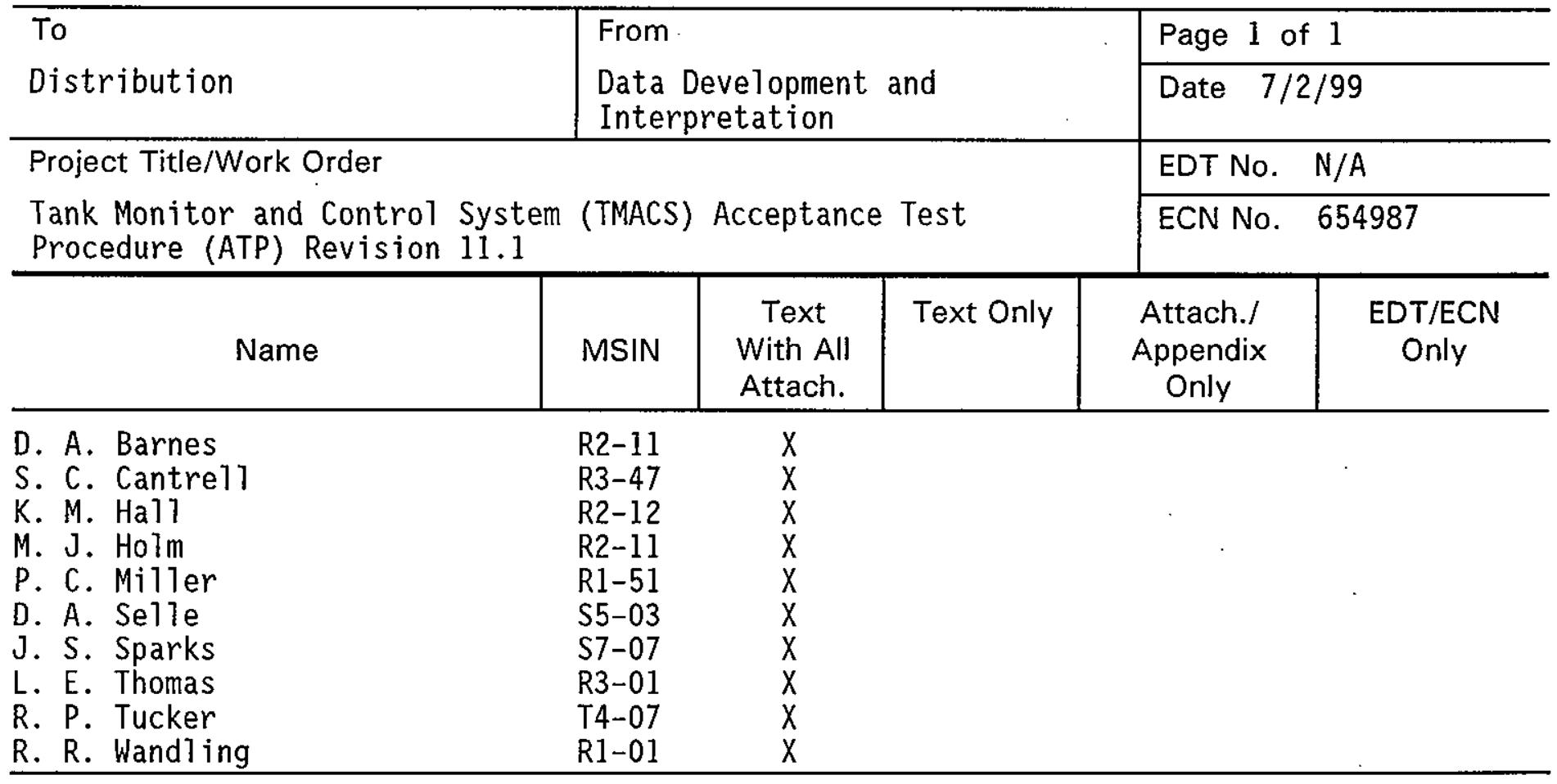


HNF-3967, Rev. 3

\section{Tank Monitor and Control System (TMACS) Acceptance Test Procedure}

M. J. Holm

Lockheed Martin Hanford Corporation, Richland, WA 99352

U.S. Department of Energy Contract DE-AC06-96RL13200

ECN: 654987

Org Code: 74B00

UC: 605

B\&R Code: EW3120071

Charge Code: 102608/EB00

Total Pages: 88

Key Words: Acceptance Test Procedure, ATP, TMACS, Tank Monitor and Control System, Rev. 11.1.

Abstract: This document is used to validate Revision 11.1 of the Tank Monitor and Control System (TMACS) and verify its functions as intended by design.

TRADEMARK DISCLAIMER, Reference herein to any specific comercial product, process, or service by trade name, trademark, manufacturer, or otherwise, does not necessarily constitute or imply its endorsement, recomendation, or favoring by the United States Government or any agency thereof or its contractors or subcontractors.

Printed in the United States of America. To obtain copies of this document, contact: Document Control Services, P.0. Box 950, Mailstop H6-08, Richland WA 99352, Phone (509) 372-2420;

Fax (509) 376-4989.
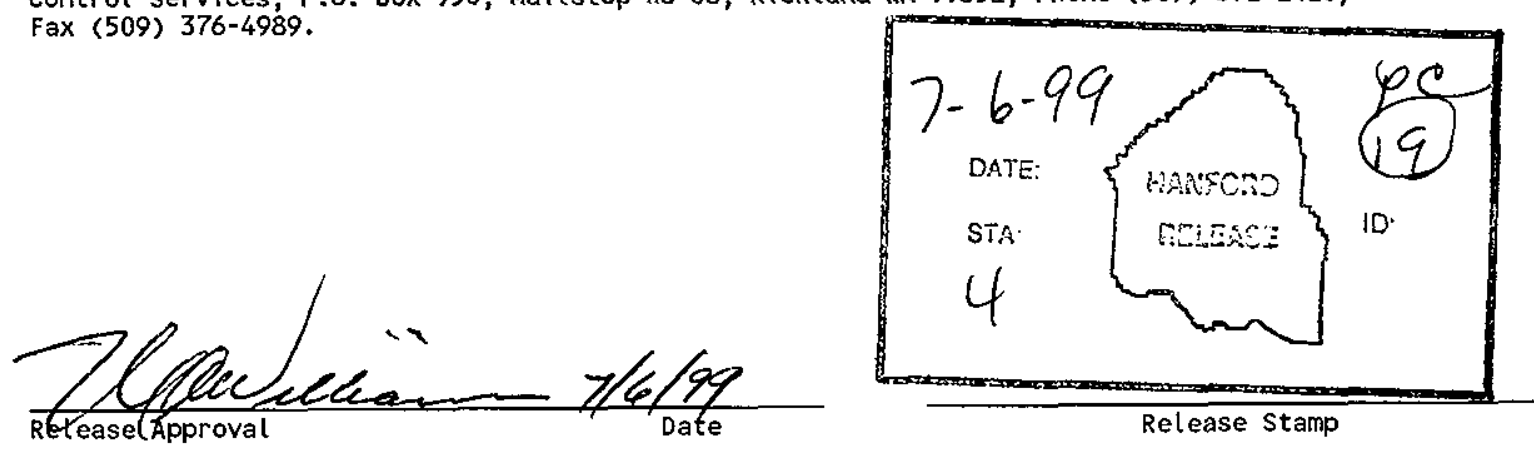

Approved for Public Release 
(2) Title

Tank Monitor and Control System (TMACS) Acceptance Test Procedure for Revision 11.1. CHANGE CONTROL RECORD

\begin{tabular}{|c|c|c|c|c|}
\hline \multirow{2}{*}{\multicolumn{2}{|c|}{ (3) Revision }} & \multirow{2}{*}{ (4) Description of Change - Replace, Add, and Delete Pages } & \multicolumn{2}{|c|}{ Authorized for Release } \\
\hline & & & (5) Cog. Engr. & (6) Cog. Mgr. \\
\hline & 0 & (7) HNF-3538 (EDT 625999) & M. J. Holm & N. W. Kirch \\
\hline & 1 & Complete revision per ECN 653556 . & M. J. Holm & N. W. Kirch \\
\hline & 2 & Complete revision per ECN 654685 . & M. J. Holm & K. M. Hall \\
\hline RS & 3 & Complete revision per ECN 654987 . & M. 3. Holm & K. M. Hall $>/ 6 / 9$ \\
\hline
\end{tabular}


HNF-3967, Rev. 3

\title{
TANK MONITOR AND CONTROL SYSTEM (TMACS) ACCEPTANCE TEST PROCEDURE
}

\author{
Prepared By \\ Ronald R. Wandling \\ Lockheed Martin Services Inc.
}

For

Lockheed Martin Hanford

For

US Department of Energy

Richland Operations Office

Richland, Washington 
HNF-3967, Rev. 3

\section{TABLE OF CONTENTS}

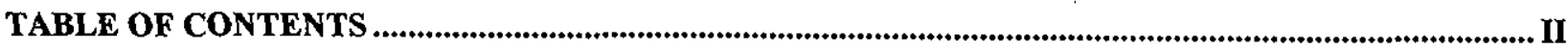

1. INTRODUCTION

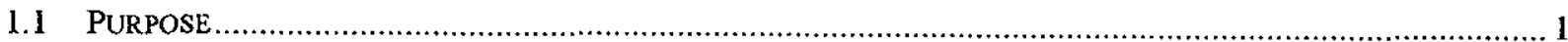

1.2 SCOPE

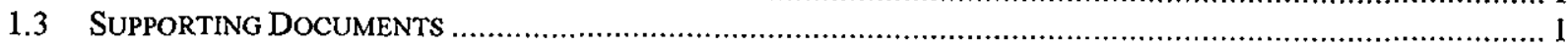

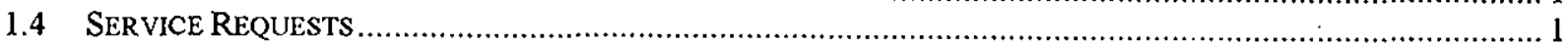

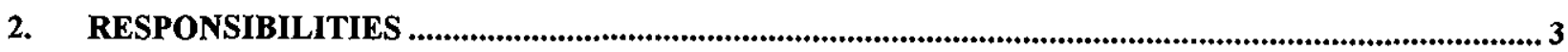

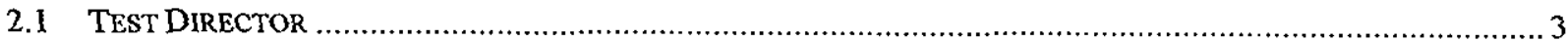

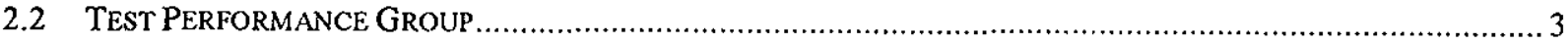

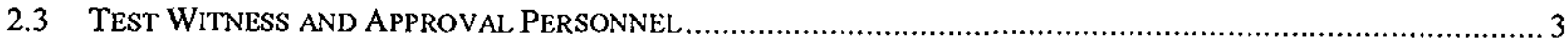

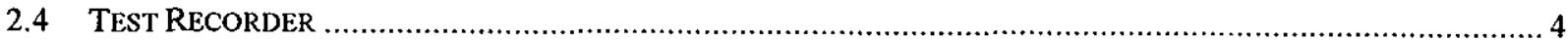

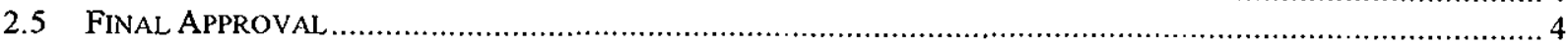

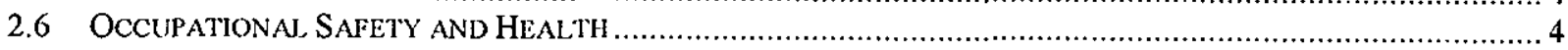

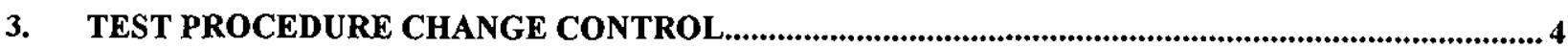

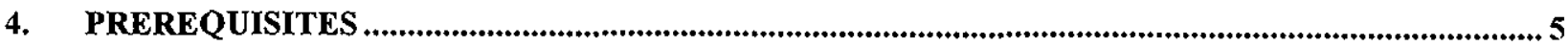

4.1 GENERAL

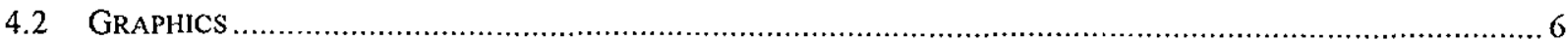

4.3 TRENDING

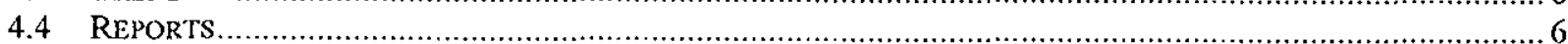

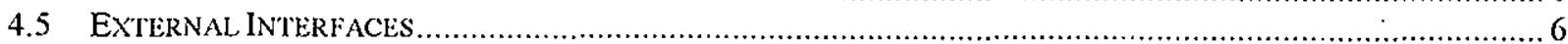

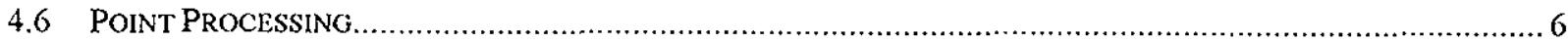

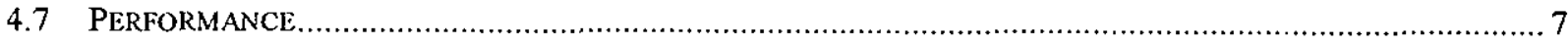

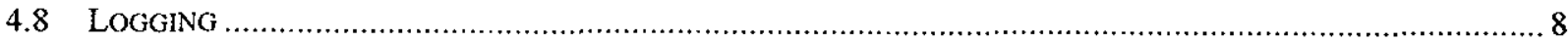

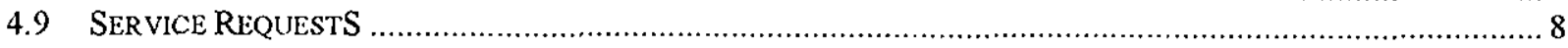

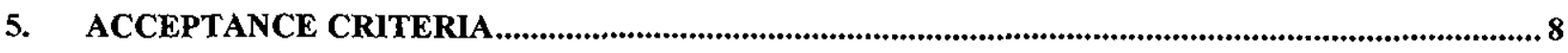

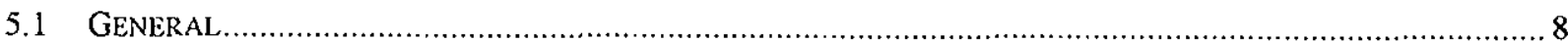

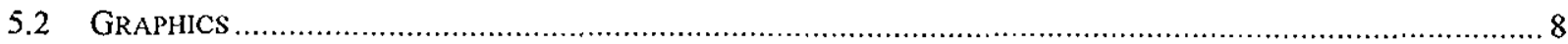

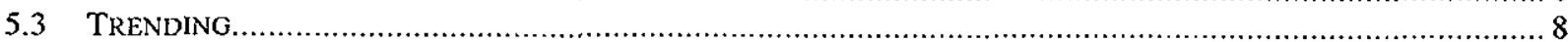

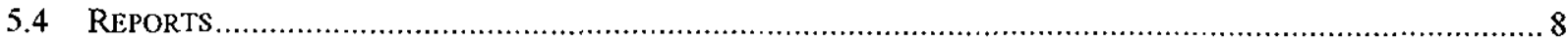

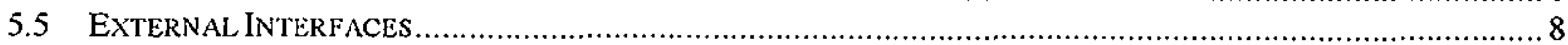

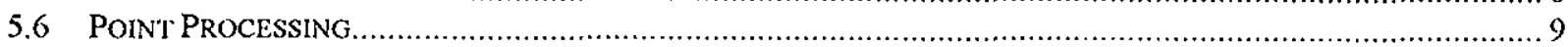

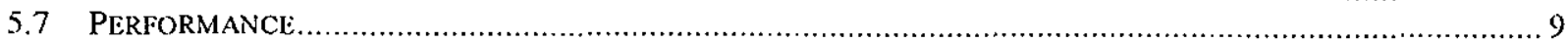

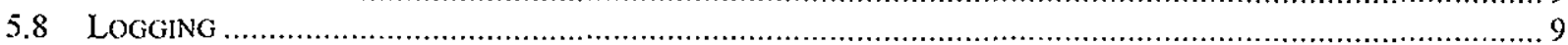

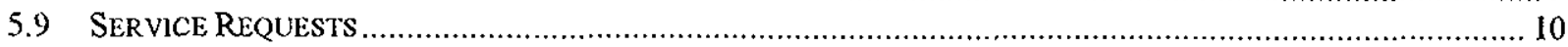

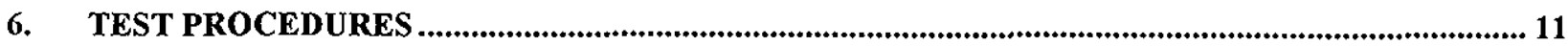

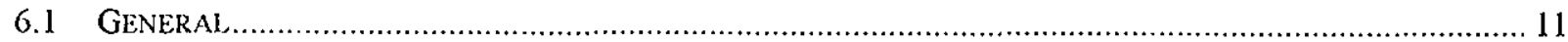

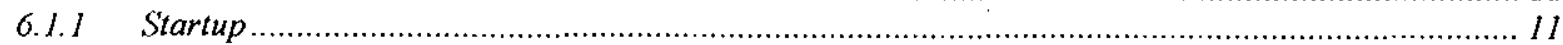

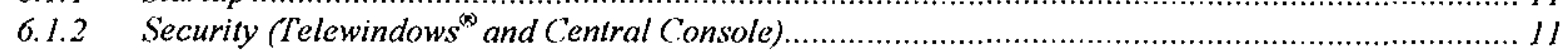

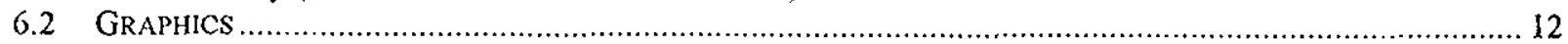

6.2.1 T2-User Abilities within TMACS:

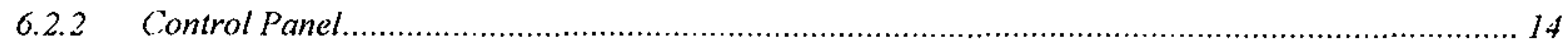

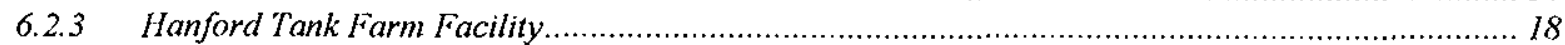

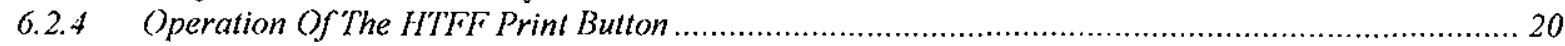

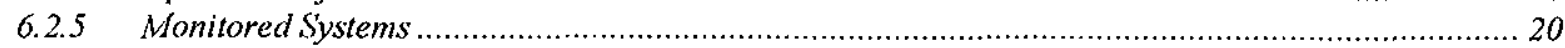

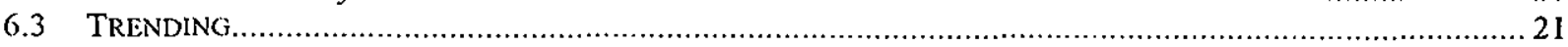

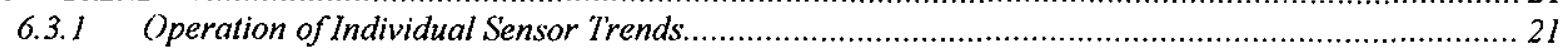




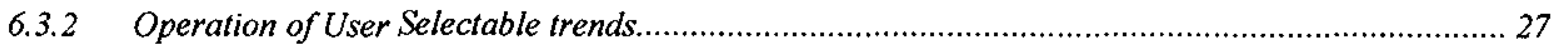

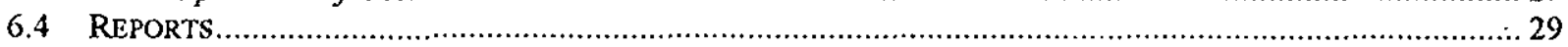

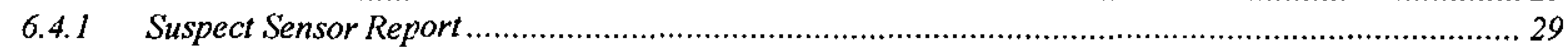

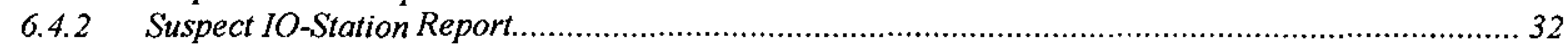

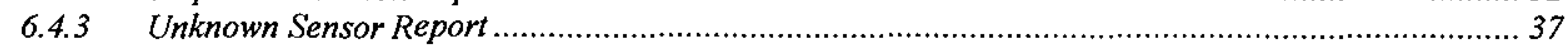

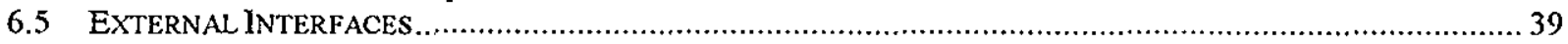

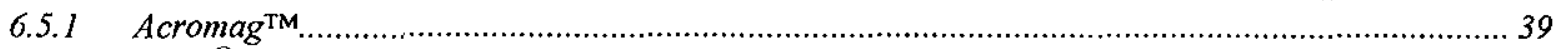

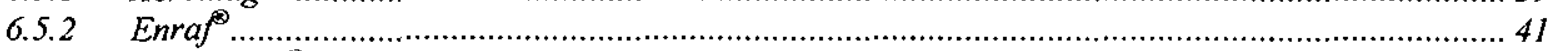

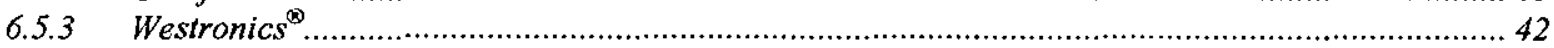

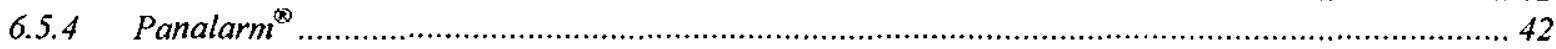

6.5.5 SACS

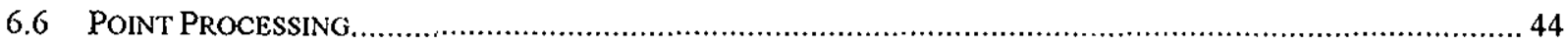

6.6.1 Continuous Sensor (Non Rate of Change) Automated Functional Test ....................................... 44

6.6.2 Continuous Sensor (Rate of Change) Automated Functional Test .............................................. 45

6.6.3 Discrete Sensor Automated Functional Test ................................................................................... 45

6.6.4 Operation of MOS T RECENT ALARM and CURRENT ALARMS ................................................ 45

6.6.5 Operation of Sensor Delta Band and Alarm Deadband …......................................................... 47

6.6.6 Operation of Enable/Disable Procedures.............................................................................. 48

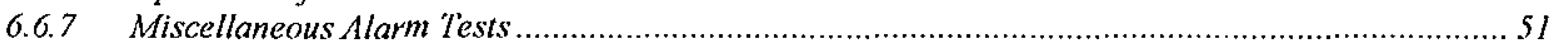

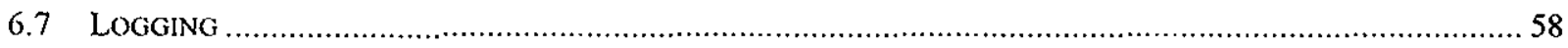

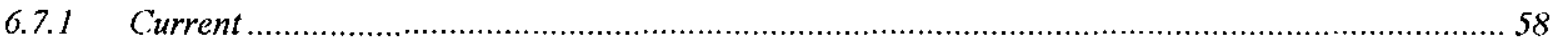

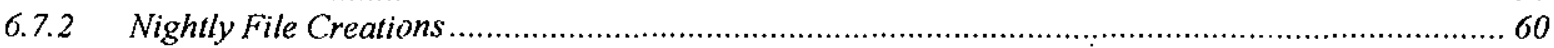

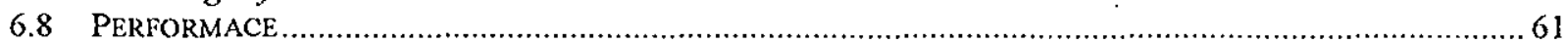

6.8.1 CPU Use Vs Number of Continuous Points/Sec Performance Test ............................................. 61

6.8.2 CPU Use Vs Number of Discrete Points/Sec Performance Test .................................................. 62

6.8.3 C.PU Use Vs Pt-Processing Function for Continuous Points Performance Test.............................. 62

6.8.4 CPU Use Vs Point-Processing Function for Discrete Points Performance Test.............................. 62

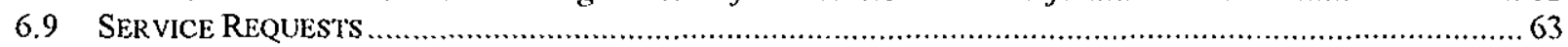

6.9.1 SR 6 - Do Not Allow Duplicate Readings From TMACS To Be Inserted Into SACS.......................63 63

6.9.2 SR 52 - Add "Point Processing" And "Alarm Processing" Features To Panalarm Sensors........... 64

6.9.3 SR 86 - Add SACS Level Sensors For Each Tank That Has A ENRAF ......................................... 64

6.9.4 SR 112 - Add Feature To Record Hourly G2 Performance Data ................................................. 64

6.9.5 SR 156-Remove Sensors Associated With The Temperature And Pressure Transmitter On Tank C-

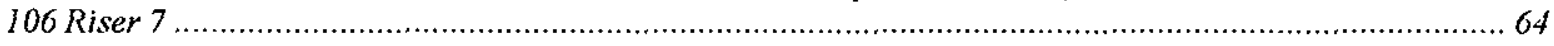

6.9.6 SR 159-Modify The Source Of BX-106 Enraf Level To Be From A CIU Instead Of An Acromag... 65

6.9.7 SR 160-Sensor Configuration Changes For Tanks TX-102 And TX-104 .................................65 65

6.9 .8 SR 165 - Eliminate Multiple Instances Of SYM-AN101-TI-RO 4A-36 .........................................65 65

6.9 .9 SR 175 - Correct AN105 SHMS Input Channels To Be 9,10,11 ................................................ 65

6.9.10 SR 179 - Correct Auto Restart Of Acromag Drivers When Connection Is Lost ................................ 66

6.9 .11 SR 417 - Set Default Reference Termomcouple Limits................................................................ 66

6.9 .12 SR 422 - Correct Start-Up Error Msg Problem......................................................................6 66

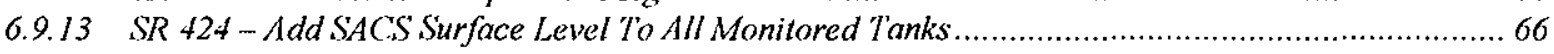

6.9.14 SR 426 - Add Disabled Sensors To SENSOR CONFIGURATION Report ................................... 66

6.9.15 SR 428 - Correct errors with $A Y$ and AZ Annotation Arrays......................................................67

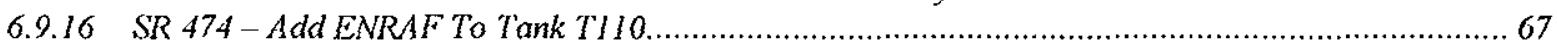

6.9.17 SR 573 - Correct Configuration Of C.106 ENRAF To Point To Riser 1 ...................................... 67

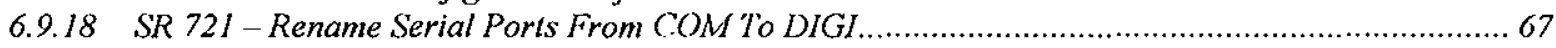

6.9.19 SR 747 - Move ENRAFS in Tanks A 101, A103 and A106 to AW CIU.....................................67

6.9.20 SR 750 - Lengthen Acromag Timeout From $180 \mathrm{Ms}$ To $500 \mathrm{Mk}$ For Acromag Connected To The

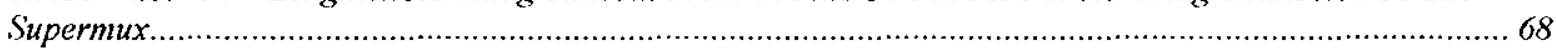

6.9.21 SR 774 - Label SHMS Cabinets Where Multiple SHMS On Tank Workspace.............................. 68

6.9.22 SR 789-Set The Alarm Limits For TMAC.S. Sensor Not Visibile To The Opeator.......................... 68

6.9.23 SR 812 - Add Cabability For Operators To Display The Data Graphed On The Single Sensor Trends 68

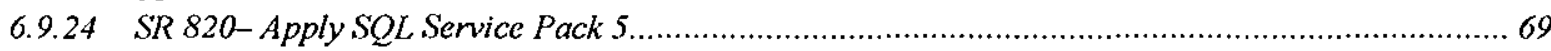

6.9.25 SR 825 - Eliminate The SACS Level Readings From The SST And DST Files.............................. 69 
6.9.26 SR 831 - Create A Report The Displays Sensors That Have Not Received A Reading Within The Last $24 \mathrm{Hrs} 70$

6.9.27 SR 832 - Create A Unknown Sensor Report. (Quality Status $=$ Unknown) ..................................... 70

6.9.28 SR 833 - Change Instrument Limits For Syl01 Enraf To Match Field Conditions.......................... 70

6.9.29 SR 834 - Correct Path/File Name Variable Used To Save Knowledge Base Upon Successful

Completion Of Engineer Control Of Alarm Limits. 70

6.9.30 SR 837 - Correct Problem Of SST And DST File Not Created When Changing To Daylight Savings

Time 70

6.9.31 SR 839 - Shorten The Delay Time For Starting Up I/O Drivers. 71

6.9.32 SR 840 - Correct Problem Of At Start-Up Where Files Are Moved To Wrong Directory Of Tfs $9 . . . .71$

6.9.33 SR 841-Configure Enraf Of Tanks AP-101 Thru AP-108, S-104, Sx-107, Sx-108 And Sx-110 Thru

$\mathrm{Sx}-11571$

6.9.34 SR 843 - Configure Enrafs For Tanks S-101, S-105, S-108, S-109 And C. 104 .......................... 73

6.9.35 SR 845 - Create A Suspect I/O Station Report................................................................... 73

6.9.36 SR 846 - Add Ability To Retrieve A Sensor Reading Upon Request.......................................... 73

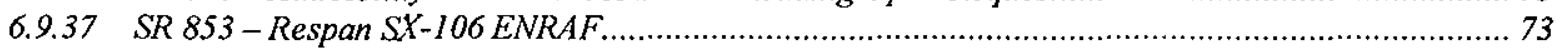

6.9.38 SR 854-Add ENRAF Annulus Leak Detectors for Tanks SY101, SY102, and SY 103................... 74

6.9.39 SR 855-Add ENRAF Level Detectors for Tanks SXI06 and SYI02 ................................... 75

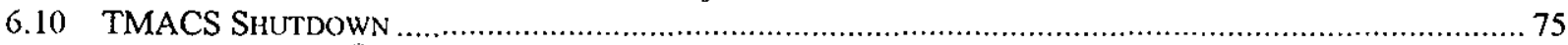

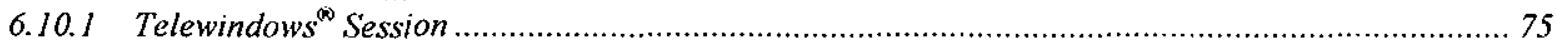

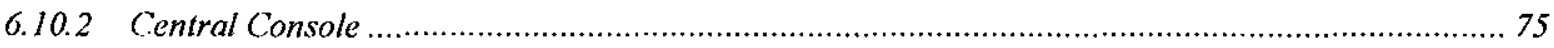

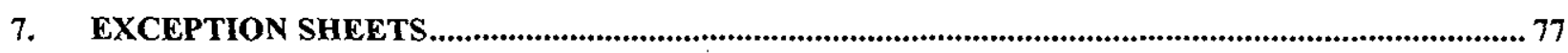

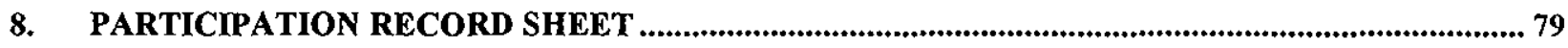

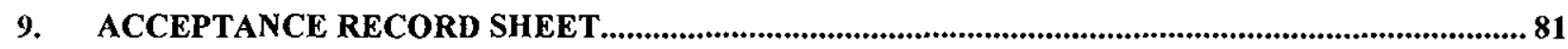


HNF-3967, Rev. 3

\section{INTRODUCTION}

\subsection{PURPOSE}

The purpose of this document is to describe tests performed to validate Revision 11.1 of the TMACS Monitor and Control System (TMACS) and verify that the software functions as intended by design.

\subsection{SCOPE}

This document is intended to test the software portion of TMACS. The tests will be performed on the development system. The software to be tested is the TMACS knowledge bases (KB) and the $\mathrm{I} / \mathrm{O}$ driver/services. The development system will not be talking to field equipment; instead, the field equipment is simulated using emulators or multiplexers in the lab.

\subsection{SUPPORTING DOCUMENTS}

- "Double-Shell Underground Waste Storage Tanks - Riser Survey," SD-RE-TI-093, Rev. 1, December 2, 1986.

- "Riser Configuration Document for Single-Shell Waste Tanks", SD-RE-TI-053, Rev, 8, August 22, 1991.

- "TMACS I/O Termination Point Listing", WHC-SD-WM-TI-594, Current Revision.

- "TMACS Data File Formats, Release 11.0," Lockheed Martin Services, Inc. External Letter, RGG-SDI-99-001.

\subsection{SERVICE REQUESTS}

The following are the services requests incorporated into the TMACS software for this release.

\begin{tabular}{|l|l|}
\hline SR \# & \multicolumn{1}{|c|}{ Abbreviated Description } \\
\hline & \\
\hline 6 & Do Not Allow Duplicate Readings From TMACS To Be Inserted Into SACS \\
\hline 52 & Add "Point Processing" And "Alarm Processing" Features To Panalarm Sensors \\
\hline 112 & Add SACS Level Sensors For Each Tank That Has A ENRAF \\
\hline 156 & $\begin{array}{l}\text { Add Feature To Record Hourly G2 Performance Data } \\
\text { Remove Sensors Associated With The Temperature And Pressure Transmitter On } \\
\text { Tank C-106 Riser 7 }\end{array}$ \\
\hline 159 & $\begin{array}{l}\text { Modify The Source Of BX-106 Enraf Level To Be From A CIU Instead Of An } \\
\text { Acromag }\end{array}$ \\
\hline
\end{tabular}




\begin{tabular}{|c|c|}
\hline $\mathrm{SR} /$ & Abbreviated Description \\
\hline 160 & Sensor Configuration Changes For Tanks TX-102 And TX-104 \\
\hline 165 & Eliminate Multiple Instances Of SYM-AN101-TI-RO4A-36 \\
\hline 175 & Correct AN105 SHMS Input Channels To Be 9,10,11 \\
\hline 179 & Correct Auto Restart Of Acromag Drivers When Connection Is Lost. \\
\hline 417 & Set Default Reference Termomcouple Limits \\
\hline 422 & Correct Start-Up Error Msg Problem. \\
\hline 424 & Add SACS Surface Level To All Monitored Tanks \\
\hline 426 & Add Disabled Sensors To SENSOR CONFIGURATION Report \\
\hline 428 & Correct Errors With AY And AZ Annotation Array. \\
\hline 474 & Add ENRAF To Tank T110 \\
\hline 573 & Correct Configuration Of C106 ENRAF To Point To Riser 1 \\
\hline 721 & Rename Serial Ports From COM To DIGI \\
\hline 747 & Move ENRAFS in Tanks A101, A103 and A106 to AW CIU \\
\hline 750 & $\begin{array}{l}\text { Lengthen Acromag Timeout From } 180 \text { Ms To } 500 \text { Ms For Acromag Connected To } \\
\text { The Supermux }\end{array}$ \\
\hline 789 & Set The Alarm Limits For TMACS Sensor Not Visibile To The Opeator \\
\hline 774 & Label SHMS Cabinets Where Multiple SHMS On Tank \\
\hline 812 & $\begin{array}{l}\text { Add Cabability For Operators To Display The Data Graphed On The Single Sensor } \\
\text { Trends }\end{array}$ \\
\hline 814 & Add Capability For Operator To Get A Reading Now \\
\hline 820 & Apply SQL Service Pack 5 \\
\hline 825 & Eliminate The SACS Level Readings From The SST And DST Files \\
\hline 831 & $\begin{array}{l}\text { Create A Report The Displays Sensors That Have Not Received A Reading Within } \\
\text { The Last } 24 \text { Hrs }\end{array}$ \\
\hline 832 & Create A Problem Sensor Report. (Quality Status = Unknown) \\
\hline 833 & Change Instrument Limits For Sy 101 Enraf To Match Field Conditions \\
\hline 834 & $\begin{array}{l}\text { Correct Path/File Name Variable Used To Save Knowledge Base Upon Successful } \\
\text { Completion Of Engineer Control Of Alarm Limits }\end{array}$ \\
\hline 837 & $\begin{array}{l}\text { Correct Problem Of Sst And Dst File Not Created When Changing To Daylight } \\
\text { Savings Time. }\end{array}$ \\
\hline 839 & Shorten The Delay Time For Starting Up I/O Drivers \\
\hline 840 & $\begin{array}{l}\text { Correct Problem Of At Start-Up Where Files Are Moved To Wrong Directory Of } \\
\text { TFS9 }\end{array}$ \\
\hline 841 & $\begin{array}{l}\text { Configure Enraf Of Tanks Ap-101 Thru Ap 108, S-104, Sx-107, Sx-108 And Sx-110 } \\
\text { Thru Sx-115 }\end{array}$ \\
\hline 843 & Configure Enrafs For Tanks S-101, S-105, S-108, S-109 And C-104 \\
\hline 845 & Create A Suspect I/O Station Report \\
\hline 846 & Add Ability To Retrieve A Sensor Reading Upon Request \\
\hline 853 & Re-span SX-106 ENRAF \\
\hline 854 & Add ENRAF Annulus Leak Detectors for Tanks SY101, SY102, and SY103 \\
\hline
\end{tabular}


HNF-3967, Rev. 3

SR $\#$ $/$ / $/$ Abbreviated Description

\begin{tabular}{l|l}
\hline 855 & Add ENRAF Level Detectors for Tanks SX106 and SY102
\end{tabular}

\section{RESPONSIBILITIES}

Each organization participating in the conduct of this ATP will designate personnel to assume the responsibilities and duties as defined herein for their respective roles. Prior to the performance of this ATP these designees shall sign the ATP Participation Sheet.

\subsection{TEST DIRECTOR}

- Provides concurrence that the ATP may commence.

- Act as liaison between the test performance group and the test witnesses.

- Shall perform the test as described in this document.

- Record exceptions and test steps that are not performed on the ATP Exception Record sheets. Add additional Exception Record sheets as needed.

- Shall obtain final approval signatures and distribute copies of the ATP.

- Stop any test that, in the judgment of the Test Director, may cause damage to the system until the test procedure has been revised.

\subsection{TEST PERFORMANCE GROUP}

- Shall provide qualified personnel, tools and equipment required to perform test.

\subsection{TEST WITNESS AND APPROVAL PERSONNEL}

- Shall observe the testing and data recording to verify that their group's requirements are met.

If any representative of the witness and approval personnel objects to the results obtained during the acceptance test, he shall notify the Test Director. Any such notice, if not resolved directly to the representative's satisfaction, shall be recorded as an exception. 
HNF-3967, Rev. 3

\subsection{TEST RECORDER}

- Get signatures on the Recorder's copy of the Acceptance Test Procedure Participation sheet prior to testing.

- Observe tests and record test data (if any).

- Initial every test step on the Recorder's copy as it is completed, next to the step number or table, when provided.

- Record exceptions and test steps, which are not performed on the Exception Sheet.

- Notify the Test Director of an exception at time the exception is made.

- Transfer Recorder's copy of the completed ATP with the final test results and signatures to the Test Director for Final Approval signatures and disposition.

\subsection{FINAL APPROVAL}

- Approval personnel shall indicate, by their signature on the ATP Acceptance Record Sheet that the ATP result's are accepted. Any questions or objections shall be referred to the Test Director for resolution.

If the approval personnel find an exception to the test that is of sufficiently small magnitude, a test approval may be given. In this case, a list of such exceptions shall be entered in the exception page as "Test Approved with Exceptions," signed and dated. This signature shall indicate that the exceptions are of such a nature that a rerun of the ATP is not necessary to demonstrate that the exceptions have been adequately resolved.

\subsection{OCCUPATIONAL SAFETY AND HEALTH}

- Individuals shall perform their assigned tasks in a safe manner to protect themselves and others from undue hazards and to prevent damage to property and environment.

\section{TEST PROCEDURE CHANGE CONTROL}

Acceptance testing shall be conducted in accordance with the steps and requirements specified in this procedure. In the event minor changes are required to successfully complete the Acceptance Test Procedure the change shall be noted as an exception and testing continued, only if the change will not effect the test acceptance criteria. The exception shall be incorporated into this document in accordance with HNF-PRO-440, "Engineering Document Change Control, Requirements." 


\section{PREREQUISITES}

This section describes the prerequisites required to perform this ATP. The section contains general prerequisites that apply to this test procedure as well as specific prerequisites for individual test procedures.

\subsection{GENERAL}

The following are the prerequisites for running any of the test sections described in this procedure.

1. The Test Director should bring up G2 ${ }^{1}$ with the TMACS_Main.KB and log in using the mode "t2-user" prior to running the formal test.

2. The Test Director should bring up a $\mathrm{G} 2^{(\mathrm{N})}$ telewindows 2 session and log in using the mode " $t 2$-user" prior to running the formal test.

3. The Test Director should verify that following bridges/services are started as services on WindowsNTTM.

\begin{tabular}{|c|c|c|}
\hline Common Name & Executable & Service Name \\
\hline Acromag $^{3} \mathrm{I} / \mathrm{O}$ driver & Acromag_driver.exe & $\begin{array}{l}\text { AcromagDriver } 22200 \\
\text { AcromagDriver } 22201 \\
\text { AcromagDriver } 22202 \\
\text { AcromagDriver } 22203 \\
\text { AcromagDriver } 22204 \\
\text { AcromagDriver } 22205\end{array}$ \\
\hline Alarm Printer driver & Tmacs_printer_driver.exe & TMACSPrtDriver 22300 \\
\hline Enraf $^{0} \mathrm{I} / \mathrm{O}$ driver & Enraf_driver.exe & EnrafDriver 22206 \\
\hline Panalarm ${ }^{4}$ I/O driver & Panalm driver.exe & PanalmDriver 22207 \\
\hline Westronic $^{5} \mathrm{I} / \mathrm{O}$ driver & Westronic driver & WestronicDriver 22212 \\
\hline G2 $2^{\infty}$ ODBC Bridge & & $\mathrm{G} 2^{\infty}$ ODBC Bridge \\
\hline
\end{tabular}

4. The Test Director shall have available the latest version of the following reference materials:

- “TMACS I/O Termination Point Listing”, (WHC-SD-WM-TI-594, current revision), document written by Instrument \& Control (I\&C). The electronic version is available at $\backslash \backslash A P 014 \backslash T M A C S$.

\footnotetext{
${ }^{1} \mathrm{G} 2$ is a registered trademark of the Gensym Corporation.

${ }^{2}$ Telewindows is a registered trademark of the Gensym Corporation.

${ }^{3}$ Acromag is a trademark of Acromag Incorporated, Wixom, Michigan.

${ }^{4}$ Panalarm is a registered trademark of Ametek, Inc.

${ }^{5}$ Westronics is a registered trademark of Westronics, Inc.
} 
- "Riser Configuration Document for Single-Shell Waste Tanks", (SD-RE-TI-053, Rev. 8).

- Double-Shell Underground Waste Storage Tanks - Riser Survey", (SD-RE-TI-093, Rev. 1).

5. The serial multiplexers or emulators for the Acromag ${ }^{\mathrm{TM}}$, Enraf ${ }^{(2)}$, Panalarm, ${ }^{(2)}$ and Westronic $^{(2)}$ devices are available. At least one serial multiplexer (or emulator) is attached to the test computer and that the appropriate driver can function through the appropriate serial port.

\subsection{GRAPHICS}

No additional prerequisites are needed.

\subsection{TRENDING}

To give a proper display of trending it is strongly advised that 1 or more days of history files be copied from production to the system to be tested (give enough time for the files to be processed) and run into the development TMACS.

\subsection{REPORTS}

No additional prerequisites are needed

\subsection{EXTERNAL INTERFACES}

No additional prerequisites are needed.

\subsection{POINT PROCESSING}

1. This test requires the system to be in a state in which no other alarm activity is generated externally. The Test Director may need to disable the collection of sensor readings from the lab equipment and clear alarm messages generated by the system start up.

2. The individual Test Cases are built using tank "Test-201", which contains one discrete and one continuous sensor. The current values for these sensors are entered programmatically; the tests assume that the following parameters have been set for sensor Continuous-200001. Verify that the sensor has the parameters in Table 1.

Table 1. Parameters for Sensor Continuous-200001

\begin{tabular}{|l|l|}
\hline Parameter & Value \\
\hline High Instrument Limit & 22 \\
\hline
\end{tabular}


HNF-3967, Rev. 3

\begin{tabular}{|l|l|}
\hline High Alarm Limit & 15 \\
\hline Low Alarm Limit & 10 \\
\hline Low Instrument Limit & 4 \\
\hline Delta Band & 0.0 \\
\hline Alarm Deadband & 0.9 \\
\hline Rate of Change & 1.2 \\
\hline ROC Limit & 2.2 \\
\hline
\end{tabular}

3. Verify that the discrete sensor, Discrete-200001, has the values for the parameters listed in Table 2.

Table 2. Parameters for Sensor Discrete-200001

\begin{tabular}{|l|l|l|}
\hline State $0=$ Normal & Color $=$ Green & Annotation = OPEN \\
\hline State $1=$ Alarm & Color $=$ Yellow & Annotation = CLOSING \\
\hline State $2=$ Alarm & Color $=$ Red & Annotation $=$ CLOSED \\
\hline State $3=$ Normal & Color $=$ Green & Annotation = OPENING \\
\hline High Instrument Limit $>3$ & Low Instrument Limit $<0$ \\
\hline
\end{tabular}

4. To set up the tests in this section the Test Director must:

- Load the testing knowledge base (KB)

- Bring up the Point Processing Functional Tests workspace

- Enter the test document revision number (i.e. 11.0).

5. The functional tests will be run individually in the test cases. The tester must be logged in to $\mathrm{G} 2$ (i) in "administrator" mode.

\subsection{PERFORMANCE}

1. This purpose of this test section is to bench mark the production software using the development computer. The tests will be performed on the computer with the minimum TMACS processes running. The development computer will be running the following software during the test:

- WindowsNT'M and related system programs that will be running in production

- $\mathrm{G} 2^{(0)}$ with the production TMACS knowledge bases. There should be no data recovery operations in place during the test!!!

- All driver services that would be running in production. None of these services should be receiving data from the field, lab, or emulators.

2. To set up the tests in this section the Test Director must: 
- Acknowledge all the alarms from the startup process

- Load the testing knowledge base (KB)

- Hide all the workspaces until only the $\mathrm{G} 2{ }^{(0)}$ background bricks appear

- Bring up the Point Processing Performance Tests workspace

- Enter the test document revision number (i.e. 11.0).

\subsection{LOGGING}

The Test Director may want to start and have the TMACS system running overnight to create the automated data files for this test.

\subsection{SERVICE REQUESTS}

\section{ACCEPTANCE CRITERIA}

\subsection{GENERAL}

The system shall provide multiple security levels that are password protected.

\subsection{GRAPHICS}

The acceptance criteria for graphics is:

- Provide real-time display of numeric values of sensors

- Communicate with a minimum of 2 graphics CRTs

- Provide "PRINT" facility for graphic window displays.

\subsection{TRENDING}

The acceptance criteria trending is:

- Provide real-time trend graphs, with the following selected time intervals: 1 hour, 7 days.

\subsection{REPORTS}

The acceptance criteria is:

- Provide a list of active sensors that have not recorded a reading for the current day.

- Provide a list of sensors that are recording readings that are unreliable. (Status unknown)

- Provide a list of io-stations that are not reporting.

\subsection{EXTERNAL INTERFACES}


The system shall be capable of providing sensor information to the Surveillance Analysis Computer System (SACS) for sensors configured in both SACS and TMACS.

The acceptance criteria sensor conversion is:

- The system shall convert the data read by the field equipment in a user readable format.

\subsection{POINT PROCESSING}

The acceptance criteria trending is:

- Provide real-time alarming on high and low level for any analog point

- Provide alarm deadband filtering for analog points

- Display the following alarm colors: red for highest priority, requiring immediate action; yellow for an abnormal condition requiring attention but not an immediate hazard; white for status indication; green for normal condition

- Provide alarm summary display with date, time, tag, description, alarm status with color-coding (green for normal). Remove message from display upon acknowledgement and reset/return to normal

- Display tanks and sensors with unacknowledged alarms as blinking

- Provide operator alarm acknowledgement. Acknowledgement action shall cease blinking of alarmed item

- Provide logging of alarms, return to normal, and alarm acknowledgements, to printer and to disk

- Provide alarming when error codes are returned from data acquisition system.

\subsection{PERFORMANCE}

The acceptance criteria trending is:

- The TMACS G2 $2^{\infty}$ program shall process input from 50 points per second while using less than $80 \%$ of the CPU time.

\subsection{LOGGING}

The acceptance criteria trending is:

- The system shall have the capability to log any sensor value 
HNF-3967, Rev. 3

- A sensor logging shall include the time stamp and the sensor's value.

\subsection{SERVICE REQUESTS}

The acceptance criteria for the service request (SR) are contained in the description of the SR. The test director will have available a copy of the service request for viewing. 


\section{TEST PROCEDURES}

\subsection{GENERAL}

\subsubsection{Startup}

Note: The Test Director prior to witness testing may have completed this test.

\begin{tabular}{|c|c|c|c|}
\hline Step & Perform & Verify & Initial \\
\hline 1. & $\begin{array}{l}\text { Start TMACS } \\
\text { On the TMACS screen, } \\
\text { type Control-Y } \\
\text { Edit the 'User' to be } \\
\text { t2-user } \\
\text { Edit the 'Password' to be } \\
\text { the password for t2-user } \\
\text { Edit the 'G2 }{ }^{(2)} \text { user mode' to } \\
\text { be t2-user }\end{array}$ & $\begin{array}{l}\text { Verify the TMACS starts up (approximately ten } \\
\text { minutes) and verify the following: } \\
\text { - A message is displayed indicating what days } \\
\text { worth of data is being recovered. } \\
\text { - A status bar is displayed indicating what } \\
\text { percentage of the days readings have been } \\
\text { read into memory. }\end{array}$ & \\
\hline
\end{tabular}

\subsubsection{Security (Telewindows ${ }^{(i)}$ and Central Console)}

\begin{tabular}{|c|c|c|c|}
\hline Step & Action & Verify & Initial \\
\hline 1. & $\begin{array}{l}\text { On the TMACS screen, } \\
\text { type Control-Y. }\end{array}$ & $\begin{array}{l}\text { Verify that the user mode selection workspace } \\
\text { appears on the screen with "t2-user" in the name } \\
\text { field. }\end{array}$ & \\
\hline 2. & $\begin{array}{l}\text { Edit the 'G2 }{ }^{(2)} \text { user mode' to } \\
\text { be something other than } \\
\text { t2-user or shut down. } \\
\text { (i.e. "administrator".) } \\
\text { Click on the END button in } \\
\text { the user mode selection } \\
\text { workspace. }\end{array}$ & $\begin{array}{l}\text { Verify that TMACS does not enter selected } \\
\text { mode. }\end{array}$ & \\
\hline 3. & $\begin{array}{l}\text { Edit the ' } G 2^{\alpha 2} \text { user mode' to } \\
\text { be "t2-user" and click on } \\
\text { the END button. }\end{array}$ & $\begin{array}{l}\text { Verify that the user mode selection workspace } \\
\text { disappears from the screen (indicating a } \\
\text { successful login). }\end{array}$ & \\
\hline
\end{tabular}


HNF-3967, Rev. 3

\subsection{GRAPHICS}

This section is performed after the system has been started and the clock is functional. This test should be performed on both the main console and Telewindows ${ }^{\infty}$.

\subsubsection{T2-User Abilities within TMACS}

\subsubsection{Central Console or Telewindows ${ }^{(i)}$}

\begin{tabular}{|c|c|c|c|}
\hline Step & Action & Verify & Initial \\
\hline & : & ManTDisplay: & \\
\hline 1. & $\begin{array}{l}\text { Click on the Show Main } \\
\text { Display button on the } \\
\text { Control Panel. }\end{array}$ & $\begin{array}{l}\text { Verify that the following workspaces appear on } \\
\text { the screen: } \\
\text { - Control Panel. } \\
\text { - Monitored Systems } \\
\text { - Most Recent Alarm. } \\
\text { - Hanford Tank Farm Facilities } \\
\text { Note: Working window (may appear if Data } \\
\text { Recovery is still running) }\end{array}$ & \\
\hline 2. & $\begin{array}{l}\text { Attempt to move several } \\
\text { objects chosen at random } \\
\text { on the workspace by doing } \\
\text { a click-and-drag. }\end{array}$ & Verify that they do not move. & \\
\hline 3. & $\begin{array}{l}\text { Click anywhere in the } \\
\text { empty space on each } \\
\text { workspace. }\end{array}$ & Verify that no menus appear. & \\
\hline & & Tank Stakus Display. & \\
\hline 4. & $\begin{array}{l}\text { Click on the tank icon for } \\
\text { any active tank. }\end{array}$ & Verify that the Tank Status workspace appears. & \\
\hline 5. & $\begin{array}{l}\text { Click on the Shrink } \\
\text { Window button on the } \\
\text { Tank Status workspace. }\end{array}$ & Verify that the workspace size is reduced. & \\
\hline 6. & $\begin{array}{l}\text { Move by dragging the } \\
\text { Tank Status Window. }\end{array}$ & $\begin{array}{l}\text { Verify that the workspace moves; verify that no } \\
\text { part of the workspace can be moved off-screen. }\end{array}$ & \\
\hline 7. & $\begin{array}{l}\text { Attempt to move several } \\
\text { objects chosen at random } \\
\text { on the Tank Status } \\
\text { workspace by doing a } \\
\text { click-and-drag. }\end{array}$ & Verify that none of the objects move. & \\
\hline & & Serisor Trend Display. & \\
\hline 8. & $\begin{array}{l}\text { Click on icon for any } \\
\text { sensor. } \\
\text { Note: Reading and Label } \\
\text { are not part of sensor icon. }\end{array}$ & $\begin{array}{l}\text { Verify that the trend workspace for that sensor } \\
\text { appears. }\end{array}$ & \\
\hline
\end{tabular}


HNF-3967, Rev. 3

\begin{tabular}{|c|c|c|c|}
\hline Step & Action & Verify & Initial \\
\hline 9. & $\begin{array}{l}\text { Click at random at several } \\
\text { places on the trend } \\
\text { workspace. }\end{array}$ & Verify that no menu appears. & \\
\hline 10. & $\begin{array}{l}\text { Attempt to move several } \\
\text { objects chosen at random } \\
\text { on the trend workspace. }\end{array}$ & Verify that none move. & \\
\hline 11. & $\begin{array}{l}\text { Click on the Hide } \\
\text { Workspace button on the } \\
\text { trend workspace. }\end{array}$ & Verify that the workspace disappears. & \\
\hline & Control ranel & \\
\hline 12. & $\begin{array}{l}\text { Move Tank Status over a } \\
\text { portion of the Control } \\
\text { Panel workspace. } \\
\text { Click on the background of } \\
\text { the Control Panel } \\
\text { workspace. }\end{array}$ & $\begin{array}{l}\text { Verify that doing so brings the Control Panel to } \\
\text { the top. }\end{array}$ & \\
\hline 13. & $\begin{array}{l}\text { Click on the Hide Window } \\
\text { button on the Tank Status } \\
\text { workspace. }\end{array}$ & Verify that the workspace disappears. & \\
\hline \multirow{2}{*}{$\frac{14}{14}$} & 2: & Montored Systems. & \\
\hline & $\begin{array}{l}\text { Click on any button on the } \\
\text { MONITORED SYSTEMS } \\
\text { workspace. }\end{array}$ & $\begin{array}{l}\text { Verify that the monitored system chosen } \\
\text { workspace appears. }\end{array}$ & \\
\hline 15. & $\begin{array}{l}\text { Click at random at several } \\
\text { places on the workspace. }\end{array}$ & Verify that no menu appears. & \\
\hline 16. & $\begin{array}{l}\text { Attempt to move several } \\
\text { objects chosen at random } \\
\text { on the workspace. }\end{array}$ & Verify that none move. & \\
\hline 17. & $\begin{array}{l}\text { Click on the Hide Window } \\
\text { button on the workspace. }\end{array}$ & Verify that the workspace disappears. & \\
\hline
\end{tabular}

\subsubsection{Central Console Only}

\begin{tabular}{|c|c|c|c|}
\hline Step & Action & Verify & Initial \\
\hline 1. & $\begin{array}{l}\text { Click on the Show Main } \\
\text { Display button on the } \\
\text { Control Panel. }\end{array}$ & $\begin{array}{l}\text { Verify that the following workspaces appear on } \\
\text { the screen: } \\
\text { - Control Panel. } \\
\text { - Monitored Systems } \\
\text { - Most Recent Alarm. } \\
\text { - Hanford Tank Farm Facilities } \\
\text { Note: Working window may appear if Data } \\
\text { Recovery is still running. }\end{array}$ & \\
\hline 2. & $\begin{array}{l}\text { Click on the tank icon for } \\
\text { any active tank. }\end{array}$ & Verify that the Tank Status workspace appears. & \\
\hline
\end{tabular}


HNF-3967, Rev. 3

\begin{tabular}{|c|c|c|c|}
\hline Step & Action & Verify & Initial \\
\hline & 2 & Ther Selectable Trends & \\
\hline 3. & $\begin{array}{l}\text { Click on a TREND } \\
\text { GRAPH button (located at } \\
\text { the bottom of the Tank } \\
\text { Workspace). }\end{array}$ & $\begin{array}{l}\text { Verify that a User Configurable Trend Graph } \\
\text { workspace appears. }\end{array}$ & \\
\hline 4. & $\begin{array}{l}\text { Click at random at several } \\
\text { places on the Trend Graph } \\
\text { workspace. }\end{array}$ & Verify that no menu appears. & \\
\hline 5. & $\begin{array}{l}\text { Attempt to move several } \\
\text { objects chosen at random } \\
\text { on the Trend Graph } \\
\text { workspace }\end{array}$ & Verify that no objects move. & \\
\hline 6. & $\begin{array}{l}\text { Click on the Hide Window } \\
\text { button on the Trend Graph } \\
\text { workspace. }\end{array}$ & Verify that the workspace disappears. & \\
\hline 7. & $\begin{array}{l}\text { Click on the Hide Window } \\
\text { button on the Tank Status } \\
\text { workspace. }\end{array}$ & Verify that the workspace disappears. & \\
\hline & & Curent $/$ arams & \\
\hline 8. & $\begin{array}{l}\text { Click on the CURRENT } \\
\text { ALARMS button on the } \\
\text { Control Panel. }\end{array}$ & $\begin{array}{l}\text { Verify that the Current Alarms workspace } \\
\text { appears. }\end{array}$ & \\
\hline 9. & $\begin{array}{l}\text { Click at random at several } \\
\text { places on the Current } \\
\text { Alarms workspace. }\end{array}$ & Verify that no menu appears. & \\
\hline 10. & $\begin{array}{l}\text { Attempt to move several } \\
\text { objects chosen at random } \\
\text { on the Current Alarms } \\
\text { workspace. }\end{array}$ & Verify that none move. & \\
\hline 11. & $\begin{array}{l}\text { Click on the Hide Window } \\
\text { button on the Current } \\
\text { Alarms workspace. }\end{array}$ & Verify that the workspace disappears. & \\
\hline
\end{tabular}

\subsubsection{Control Panel}

\subsubsection{Operation of the SHOW MAIN DISPLAY button}

\begin{tabular}{|l|l|l|l|}
\hline Step & \multicolumn{1}{|c|}{ Perform } & \multicolumn{1}{|c|}{ Expected Result } & Initial \\
\hline 1. & $\begin{array}{l}\text { Click on any enabled Tank } \\
\text { Icon in the Hanford Tank } \\
\text { Farm Facilities. (The icon } \\
\text { will not be gray.) If the } \\
\text { Tank Status Window is not } \\
\text { already shrunk then click } \\
\text { it's Shrink Window button }\end{array}$ & $\begin{array}{l}\text { Verify that a Tank Status workspace appears } \\
\text { for the selected tank and that the Control Panel }\end{array}$ & \\
is visible. & & \\
\hline
\end{tabular}


HNF-3967, Rev. 3

\begin{tabular}{|c|c|c|c|}
\hline Step & Perform & Expected Result & Initial \\
\hline & (an $\nabla$ as a symbol). & & \\
\hline 2. & $\begin{array}{l}\text { Click on the Show Main } \\
\text { Display button on the } \\
\text { Control Panel. }\end{array}$ & $\begin{array}{l}\text { Verify that the Tank Status workspace } \\
\text { disappears. } \\
\text { Verify that the following workspaces appear on } \\
\text { the screen: } \\
\text { - Hanford Tank Farm Facilities } \\
\text { - Control Panel } \\
\text { - Most Recent Alarm (may be partially } \\
\text { covered by the Hanford Tank Farm } \\
\text { Facilities workspace) } \\
\text { - Monitored Systems } \\
\text { Note: Working window may appear if Data } \\
\text { Recovery is still running. }\end{array}$ & \\
\hline \multirow[t]{7}{*}{3.} & $\begin{array}{l}\text { Examine the TMACS } \\
\text { display. }\end{array}$ & $\begin{array}{l}\text { Verify that the Control Panel workspace is } \\
\text { located in the upper right-hand corner. }\end{array}$ & \\
\hline & & $\begin{array}{l}\text { Verify that the following objects appear in the } \\
\text { workspace in order, top to bottom: } \\
\text { - Label "Control Panel" } \\
\text { - SHOW MAIN DISPLAY button } \\
\text { - CURRENT ALARMS button (Not } \\
\text { - } \quad \text { Nuailable to Telewindows" sessions) } \\
\text { - } \quad \text { HIDE SENSOR TRENDS button } \\
\text { - REPORT MENU button } \\
\text { - A date and time display }\end{array}$ & \\
\hline & & $\begin{array}{l}\text { Verify that MONITORED SYSTEMS } \\
\text { workspace is displayed on the middle right- } \\
\text { hand side of the screen and is displaying the } \\
\text { following: } \\
\text { - AY/AZ Exhauster } \\
\text { - C-106 Sluicing } \\
\text { - K-Basins }\end{array}$ & \\
\hline & & $\begin{array}{l}\text { Verify that the Most Recent Alarm workspace } \\
\text { is in the lower right-hand corner and that the } \\
\text { GOTO button appears at the top center of the } \\
\text { workspace. }\end{array}$ & \\
\hline & & $\begin{array}{l}\text { Verify that the Number of Current Alarms } \\
\text { digital display is located at the top right of the } \\
\text { Most Recent Alarm workspace. }\end{array}$ & \\
\hline & & $\begin{array}{l}\text { Verify that the Hanford Tank Farm Facilities } \\
\text { workspace occupies the left portion of the } \\
\text { screen. }\end{array}$ & \\
\hline & & Verify that a brown background appears behind & \\
\hline
\end{tabular}




\begin{tabular}{|c|c|l|c|}
\hline Step & \multicolumn{1}{|c|}{ Perform } & \multicolumn{1}{|c|}{ Expected Result } & Initial \\
\hline & & $\begin{array}{l}\text { these workspaces and that no other workspaces } \\
\text { are visible. }\end{array}$ & \\
\hline
\end{tabular}

\subsubsection{Operation of CURRENT ALARMS Button and Screen}

Note: The CURRENT ALARMS button is not available in a Telewindows ${ }^{(2)}$ session.

\begin{tabular}{|c|c|c|c|}
\hline Step & Perform & Expected Result & Initial \\
\hline 1. & $\begin{array}{l}\text { Click on the CURRENT } \\
\text { ALARMS button on the } \\
\text { Control Panel.. }\end{array}$ & $\begin{array}{l}\text { Verify that the Current Alarms workspace } \\
\text { appears on the left-hand side of the screen and } \\
\text { contains the following: } \\
\text { - HIDE WINDOW (with an x as a symbol) } \\
\text { - } \text { SHRINK WINDOW (an as a symbol) } \\
\text { - } \text { EXPAND WINDOW (an } \triangle \text { as a symbol) } \\
\text { - CURRENT-ALARMS title box } \\
\text { - UP ONE ALARM } \\
\text { - UP ONE PAGE } \\
\text { - } \text { REFRESH ALARMS } \\
\text { - } \text { DOWN ONE PAGE } \\
\text { - GO TO TOP of LIST } \\
\text { - GO TO END of LIST } \\
\text { ACKNOWLEDGE ALL WHITE } \\
\text { ALARMS } \\
\text { ACKNOWLEDGE ALL BLUE } \\
\text { MESSAGES }\end{array}$ & \\
\hline \multicolumn{4}{|c|}{ Operation of the SUIRWK WINOOW button: } \\
\hline 2. & $\begin{array}{l}\text { Note: If the Current } \\
\text { Alarms workspace is } \\
\text { already shrunk then } \\
\text { expand first. } \\
\text { Click on the SHRINK } \\
\text { WINDOW button. }\end{array}$ & $\begin{array}{l}\text { Verify the Current Alarms workspace: } \\
\text { - Decreases in size } \\
\text { - Moves to the left-hand side of the screen } \\
\text { - Has space to show } 10 \text { alarms. (Only } \\
9 \text { alarms will be visible if the first alarm in } \\
\text { the list is visible.) }\end{array}$ & \\
\hline \multicolumn{4}{|c|}{ (. } \\
\hline 3. & $\begin{array}{l}\text { Click on the EXPAND } \\
\text { WINDOW button. }\end{array}$ & $\begin{array}{l}\text { Verify the Current Alarms workspace: } \\
\text { - Increases in size } \\
\text { - Moves to the left-hand side of the screen } \\
\text { - Has space to show } 6 \text { alarms. (Only } \\
5 \text { alarms will be visible if the first alarm in } \\
\text { the list is visible.) }\end{array}$ & \\
\hline \multicolumn{4}{|c|}{ 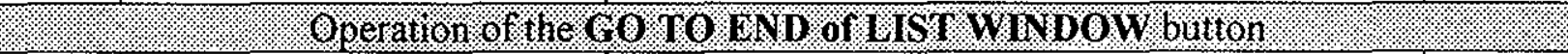 } \\
\hline 4. & Click on the GO TO END & Verify the last page of current alarms is & \\
\hline
\end{tabular}




\section{Error}

An error occurred while processing this page. See the system log for more details. 
HNF-3967, Rev. 3

\begin{tabular}{|c|c|c|c|}
\hline Step & Perform & Expected Result & Initial \\
\hline 2. & $\begin{array}{l}\text { Click on several sensor } \\
\text { trend icons selected at } \\
\text { random. }\end{array}$ & $\begin{array}{l}\text { Verify that Sensor Trend workspaces for the } \\
\text { selected sensors appear. }\end{array}$ & \\
\hline 3. & $\begin{array}{l}\text { Lift the Control Panel to } \\
\text { the top by clicking in the } \\
\text { blank background on the } \\
\text { Control Panel workspace. } \\
\text { Click on the HIDE } \\
\text { SENSOR TRENDS button } \\
\text { on the Control Panel. }\end{array}$ & $\begin{array}{l}\text { Verify that the Tank Status workspace and any } \\
\text { Sensor Trend workspaces are hidden. }\end{array}$ & \\
\hline
\end{tabular}

\subsubsection{Operation of the REPORTS button}

\begin{tabular}{|c|c|c|c|}
\hline Step & Perform & Expected Result & Initial \\
\hline 1. & $\begin{array}{l}\text { Click on the REPORT } \\
\text { MENU button on the } \\
\text { Control Panel. }\end{array}$ & $\begin{array}{l}\text { Verify that the Report Menu workspace is } \\
\text { displayed with a list of report buttons that } \\
\text { includes the following: } \\
\text { - Suspect Sensor Report } \\
\text { - Suspect IO-Station Report } \\
\text { - Unknown Sensor Report }\end{array}$ & \\
\hline 2. & $\begin{array}{l}\text { Select a report at random. } \\
\text { Click on the Title of the } \\
\text { report. }\end{array}$ & $\begin{array}{l}\text { Verify the Help workspace for the chosen } \\
\text { report is displayed. }\end{array}$ & \\
\hline 3. & Click on the hide button. & Verify the workspace disappears. & \\
\hline 4. & $\begin{array}{l}\text { Select a report at random } \\
\text { Click on the button for the } \\
\text { chosen report. }\end{array}$ & $\begin{array}{l}\text { Verify the chosen report's workspace is } \\
\text { displayed. (Note: The verification of the report } \\
\text { is performed elsewhere in this document.) }\end{array}$ & \\
\hline 5. & Click on the hide button. & Verify the workspace disappears. & \\
\hline 6. & $\begin{array}{l}\text { Click on the hide button on } \\
\text { Report Menu workspace. }\end{array}$ & Verify the workspace disappears. & \\
\hline
\end{tabular}

\subsubsection{Hanford Tank Farm Facility}




\subsubsection{Operation of a TANK ICON button}

\begin{tabular}{|c|c|c|c|}
\hline Step & Perform & Expected Result & Initial \\
\hline 1. & $\begin{array}{l}\text { Click any enabled Tank } \\
\text { Icon in the Hanford Tank } \\
\text { Farm Facilities. (The icon } \\
\text { will not be gray.) }\end{array}$ & $\begin{array}{l}\text { Verify that the Tank Status workspace appears } \\
\text { on the screen and contains the following: } \\
\text { - TITLE (correctly identifying the tank) } \\
\text { - HIDE WINDOW button ( } \mathrm{x} \text { as a symbol) } \\
\text { - } \text { SHRINK WINDOW button (an } \nabla \text { as a } \\
\text { symbol) } \\
\text { - EXPAND WINDOW button (an } \Delta \text { as a } \\
\text { symbol) } \\
\text { - ACK ALARMS button } \\
\text { - UPDATE button (if available, not all tanks } \\
\text { - } \text { have discrete sensors). } \\
\text { appropriate Tank Riser Configuration } \\
\text { Documents for correct location) } \\
\text { - Print Screen button } \\
\text { - Riser Identifier(s) (displayed over the } \\
\text { riser(s)) } \\
\text { - Unser Icons (i.e. thermocouple, level) } \\
\text { User Selectable Trend button(s). }\end{array}$ & \\
\hline \multicolumn{4}{|c|}{ Thernocouple Operation: } \\
\hline 2. & $\begin{array}{l}\text { Use the document } \\
\text { "TMACS I/O Termination } \\
\text { Point Listing" (Tag list) as } \\
\text { a reference. Choose a } \\
\text { thermocouple for the tank. }\end{array}$ & $\begin{array}{l}\text { Verify the following: } \\
\text { - The thermocouple is positioned on the tank } \\
\text { display in a way that approximates the } \\
\text { physical location in the tank. } \\
\text { - Sensor label and current value are displayed } \\
\text { next to the thermocouple icon } \\
\text { - Sensor icon is overlaid with the sensor } \\
\text { alarm status color }\end{array}$ & \\
\hline \multicolumn{4}{|c|}{ Qperation of Trank Level Tidication? } \\
\hline 3. & $\begin{array}{l}\text { Use the document } \\
\text { "TMACS I/O Termination } \\
\text { Point Listing" (Tag list) as } \\
\text { a reference. Choose a } \\
\text { surface level sensor for the } \\
\text { tank. }\end{array}$ & $\begin{array}{l}\text { Verify the following: } \\
\text { - The surface level icon(s) is positioned } \\
\text { proportionally to the maximum tank height } \\
\text { and at the current level displayed by the } \\
\text { reading. } \\
\text { - Sensor label and current value are displayed } \\
\text { next to the surface level icon. The label } \\
\text { should identifying the source of this } \\
\text { reading. (ENRAF' or SACS) } \\
\text { - Sensor icon is overlaid with the sensor } \\
\text { alarm status color }\end{array}$ & \\
\hline
\end{tabular}




\begin{tabular}{|c|c|c|c|}
\hline Step & Perform & Expected Result & Initial \\
\hline \multicolumn{4}{|c|}{ 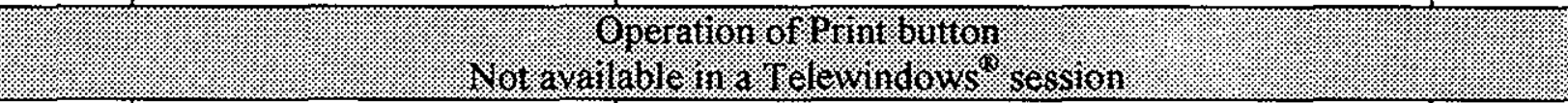 } \\
\hline 4. & $\begin{array}{l}\text { Click on the PRINT } \\
\text { SCREEN button. }\end{array}$ & Verify that the tank workspace prints. & \\
\hline \multicolumn{4}{|c|}{ 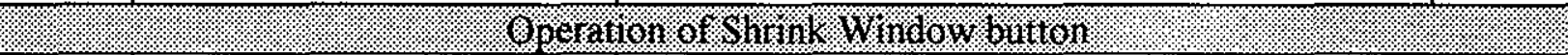 } \\
\hline 5. & $\begin{array}{l}\text { Click on the SHRINK } \\
\text { WINDOW button (an } \nabla \text { as } \\
\text { a symbol). }\end{array}$ & Verify that the workspace shrinks. & \\
\hline 6. & $\begin{array}{l}\text { Drag the Tank Status } \\
\text { workspace to the upper } \\
\text { right hand corner. }\end{array}$ & $\begin{array}{l}\text { Verify that the Tank Status workspace stops at } \\
\text { the edge of the screen when dragged to the top } \\
\text { or to the right. }\end{array}$ & \\
\hline \multicolumn{4}{|c|}{ Operation of Expand Wirdow butron } \\
\hline 7. & $\begin{array}{l}\text { Click on the EXPAND } \\
\text { WINDOW button (an } \\
\text { as a symbol). }\end{array}$ & Verify that the workspace enlarges. & \\
\hline \multicolumn{4}{|c|}{ Operation of the MUDE button. } \\
\hline 8. & $\begin{array}{l}\text { Click on the HIDE } \\
\text { WINDOW. }\end{array}$ & Verify that the workspace is hidden. & \\
\hline Note: & $\begin{array}{l}\text { peration of the Acknowled } \\
\text { ests) }\end{array}$ & Alarm button is performed in section 6.6 .7 & $n$ \\
\hline
\end{tabular}

\subsubsection{Operation Of The HTFF Print Button}

Note: The CURRENT ALARMS button is not available in a Telewindows ${ }^{(\xi)}$ session.

\begin{tabular}{|l|l|l|l|}
\hline Step & \multicolumn{1}{|c|}{ Perform } & \multicolumn{1}{c|}{ Expected Result } & Initial \\
\hline 1. & $\begin{array}{l}\text { Click on the PRINT } \\
\text { SCREEN button in the } \\
\text { lower right hand corner of } \\
\text { workspace. (May have to } \\
\text { lick on HTTF workspace } \\
\text { to see button) }\end{array}$ & Verify that the workspace is printed. & \\
\hline
\end{tabular}

\subsubsection{Monitored Systems}

\subsubsection{Operation Of The Monitored System Button}

\begin{tabular}{|l|l|l|c|}
\hline Step & \multicolumn{1}{|c|}{ Perform } & \multicolumn{1}{c|}{ Expected Result } & Initial \\
\hline 1. & $\begin{array}{l}\text { Click on the any system } \\
\text { displayed on the } \\
\text { MONITORED SYSTEMS } \\
\text { workspace. }\end{array}$ & $\begin{array}{l}\text { Verify that a workspace is dispiayed } \\
\text { representing the monitored system. }\end{array}$ & \\
\hline
\end{tabular}


HNF-3967, Rev. 3

\begin{tabular}{|c|c|c|c|}
\hline Step & Perform & Expected Result & Initial \\
\hline 2. & $\begin{array}{l}\text { Click on the sensor } \\
\text { objects. }\end{array}$ & $\begin{array}{l}\text { Verify that no graphic workspaces or menu } \\
\text { boxes are displayed. }\end{array}$ & \\
\hline 3. & $\begin{array}{l}\text { For alarm panels, click on } \\
\text { any graphic "borders". }\end{array}$ & $\begin{array}{l}\text { Verify that no graphic workspaces or menu } \\
\text { boxes are displayed. }\end{array}$ & \\
\hline \multicolumn{4}{|c|}{ 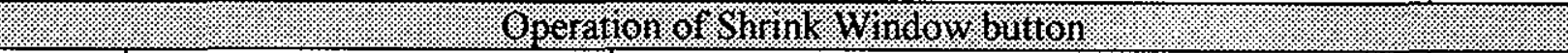 } \\
\hline & $\begin{array}{l}\text { Click on the SHRINK } \\
\text { WINDOW button (an } \nabla \text { as } \\
\text { a symbol). }\end{array}$ & Verify that the workspace shrinks. & \\
\hline & $\begin{array}{l}\text { Drag the workspace to the } \\
\text { upper right hand corner. }\end{array}$ & $\begin{array}{l}\text { Verify that the workspace stops at the edge of } \\
\text { the screen when dragged to the top or to the } \\
\text { right. }\end{array}$ & \\
\hline \multicolumn{4}{|c|}{ 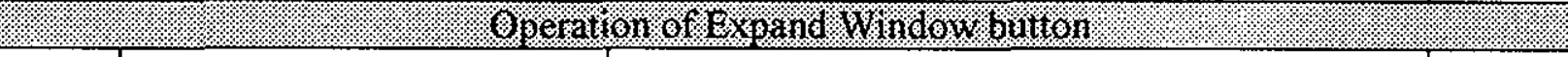 } \\
\hline & $\begin{array}{l}\text { Click on the EXPAND } \\
\text { WINDOW button (an } \\
\text { as a symbol). }\end{array}$ & Verify that the workspace enlarges. & \\
\hline \multicolumn{4}{|c|}{ Operation of f he VIIOE button } \\
\hline & $\begin{array}{l}\text { Click on the HIDE } \\
\text { WINDOW. }\end{array}$ & Verify that the workspace is hidden. & \\
\hline
\end{tabular}

\subsection{TRENDING}

This section describes the test cases for both the individual and user selectable trends.

Have the Test Director verify that the TMACS is running in Development Mode of operation and is generating variable sensor data. Note: $\mathrm{G} 2{ }^{(0)}$ will only display trend data that varies over time.

\subsubsection{Operation of Individual Sensor Trends}

This section describes the test cases for the individual selectable trends.

\subsubsection{Operation of Trend Chart}

\begin{tabular}{|l|l|l|c|}
\hline Step & \multicolumn{1}{|c|}{ Perform } & \multicolumn{1}{|c|}{ Expected Result } & Initial \\
\hline 1. & Click any enabled Tank Icon & Verify that a Sensor Trend workspace for the & \\
in the Hanford Tank Farm & sensor chosen and contains the following. & \\
Facilities. (The icon will not & $\bullet$ Chart & \\
be gray.) & - HIDE WINDOW $(X)$ button & \\
& $\begin{array}{l}\text { Click on the portion of any } \\
\text { sensor icon that looks like a } \\
\text { little chart. }\end{array}$ & - DETAIL $(D)$ button. & \\
\hline
\end{tabular}




\begin{tabular}{|c|c|c|c|}
\hline Step & Perform & Expected Result & Initial \\
\hline 2. & Examine theChart. & $\begin{array}{l}\text { Verify the following: } \\
\text { - The values line color is black. } \\
\text { - Lines for the low and high alarm limits } \\
\text { appear at roughly one-tenth }(1 / 10) \text { and } \\
\text { nine tenths (9/10) of the distance on the } \\
\text { vertical axis. Note: Only if trend is } \\
\text { within limits. } \\
\text { - Alarm limit bands match the alarm color } \\
\text { (Yellow or Red). } \\
\text { - The trend title (above) and label (below) } \\
\text { agree with the sensor tag name and } \\
\text { descriptor. } \\
\text { - The time scale of the horizontal time axis } \\
\text { is } 7 \text { days and that some dates are shown. }\end{array}$ & \\
\hline 3. & Click on the Print button. & $\begin{array}{l}\text { Verify the Sensor Trend workspace is } \\
\text { printed. }\end{array}$ & \\
\hline 4. & $\begin{array}{l}\text { Click on the HIDE } \\
\text { WINDOW button. }\end{array}$ & Verify that the workspace is hidden. & \\
\hline
\end{tabular}

\subsubsection{Operation of Sensor Details}

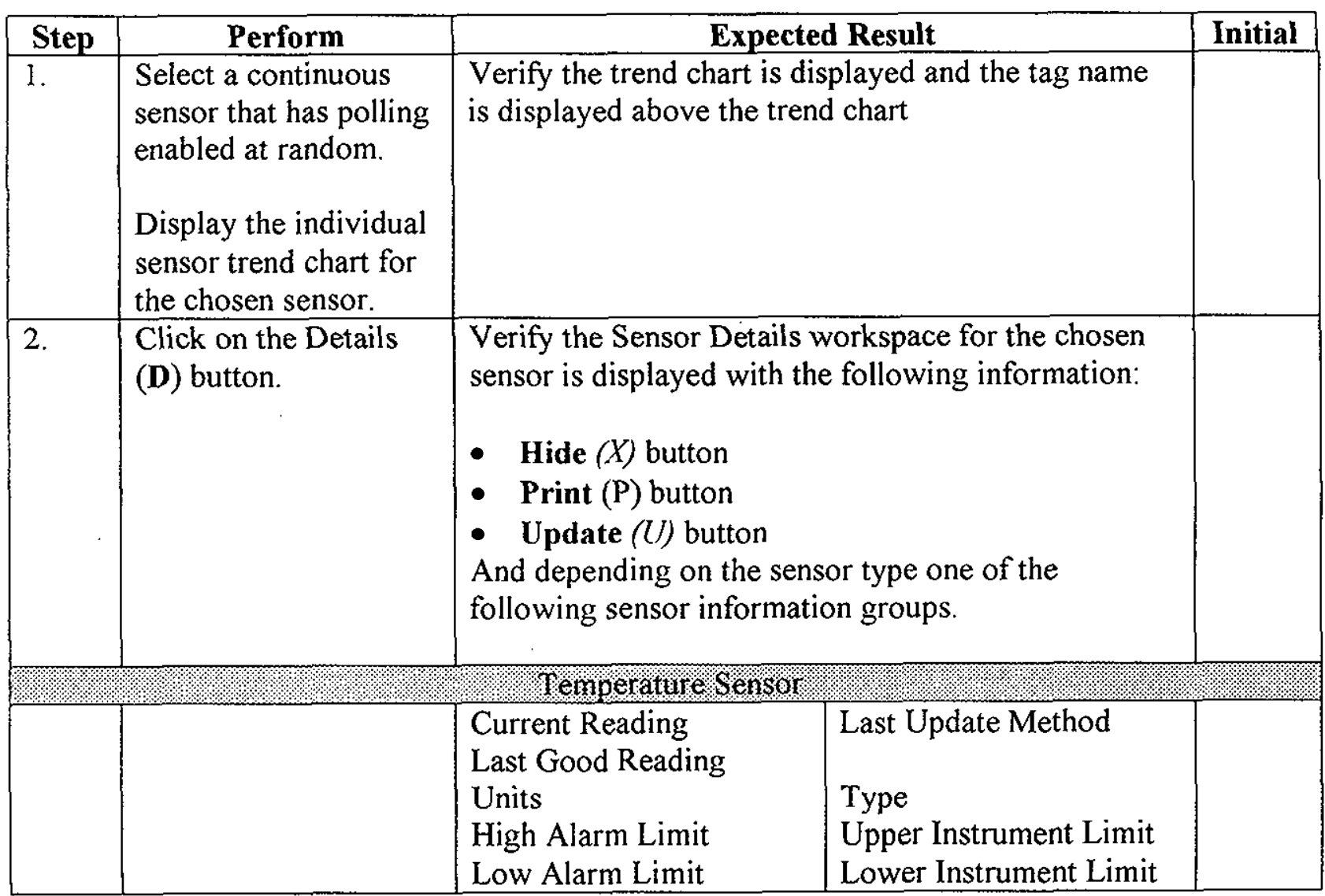


HNF-3967, Rev. 3

\begin{tabular}{|c|c|c|c|c|}
\hline Step & Perform & \multicolumn{2}{|c|}{ Expected Result } & Initial \\
\hline & & $\begin{array}{l}\text { Deadband } \\
\text { Point Processing } \\
\text { ROC Processing } \\
\text { Station Status } \\
\text { Polling Freq. Index } \\
\text { Validity Interval } \\
\text { Expiration Time } \\
\text { Formula Expression } \\
\text { Formula Parameter }\end{array}$ & $\begin{array}{l}\text { Delta } \\
\text { Alarm Processing } \\
\text { Logging } \\
\text { Raw Value } \\
\text { Polling. Freq. Sec. }\end{array}$ & \\
\hline \multicolumn{5}{|c|}{ SAOS V EVIEI Scnsor } \\
\hline & & $\begin{array}{l}\text { Current Reading } \\
\text { Last Good Reading } \\
\text { Units } \\
\text { High Alarm Limit } \\
\text { Low Alarm Limit } \\
\text { Deadband } \\
\text { Point Processing } \\
\text { ROC Processing } \\
\text { Suspect Status } \\
\text { Sensor Type Name } \\
\text { Slvl dttm } \\
\end{array}$ & $\begin{array}{l}\text { Last Update Method } \\
\text { Upper Instrument Limit } \\
\text { Lower Instrument Limit } \\
\text { Delta } \\
\text { Alarm Processing } \\
\text { Logging }\end{array}$ & \\
\hline \multicolumn{5}{|c|}{ ENR A F L EVEL SCNSOr } \\
\hline & & $\begin{array}{l}\text { Current Reading } \\
\text { Last Good Reading } \\
\text { Units } \\
\text { High Alarm Limit } \\
\text { Low Alarm Limit } \\
\text { Deadband } \\
\text { Point Processing } \\
\text { ROC Processing } \\
\text { Station Status } \\
\text { Polling Freq. Index } \\
\text { Displacer Postion } \\
\text { Level Status } \\
\text { Alarm Status } \\
\text { Validity Interval } \\
\text { Expiration Time } \\
\text { Formula Expression } \\
\text { Formula Parameter }\end{array}$ & $\begin{array}{l}\text { Last Update Method } \\
\text { Upper Instrument Limit } \\
\text { Lower Instrument Limit } \\
\text { Delta } \\
\text { Alarm Processing } \\
\text { Logging } \\
\text { Raw Value } \\
\text { Polling. Freq. Sec. } \\
\text { Waste Level } \\
\text { Level Status Mode } \\
\text { Alarm Status Mode }\end{array}$ & \\
\hline \multicolumn{5}{|c|}{ Oothe Sersors. } \\
\hline & - & $\begin{array}{l}\text { Current Reading } \\
\text { Last Good Reading } \\
\text { Units } \\
\text { High Alarm Limit } \\
\text { Low Alarm Limit }\end{array}$ & $\begin{array}{l}\text { Last Update Method } \\
\text { Upper Instrument Limit } \\
\text { Lower Instument Limit }\end{array}$ & \\
\hline
\end{tabular}


HNF-3967, Rev. 3

\begin{tabular}{|c|c|c|c|c|}
\hline Step & Perform & \multicolumn{2}{|c|}{ Expected Result } & Initial \\
\hline & & $\begin{array}{l}\text { Deadband } \\
\text { Point Processing } \\
\text { ROC Processing } \\
\text { Station Status } \\
\text { Polling Freq. Index } \\
\text { Validity Interval } \\
\text { Expiration Time } \\
\text { Formula Expression } \\
\text { Formula Parameter }\end{array}$ & $\begin{array}{l}\text { Delta } \\
\text { Alarm Processing } \\
\text { Logging } \\
\text { Raw Value } \\
\text { Polling. Freq. Sec. }\end{array}$ & \\
\hline 3. & $\begin{array}{l}\text { Click the Update } \\
\text { button. } \\
\text { Wait for the } \\
\text { workspace to be } \\
\text { updated } \\
\text { (approximately } 5 \\
\text { seconds). } \\
\text { Note: Not Valid for } \\
\text { SACS_LEVEL Sensors } \\
\text { at this time. }\end{array}$ & \multicolumn{2}{|c|}{$\begin{array}{l}\text { Verify the following: } \\
\text { - The date and time displayed in the Readout Last } \\
\text { Good Reading At is updated. } \\
\text { - Reading displayed in the Current Reading is } \\
\text { updated. } \\
\text { - RPC is displayed in the readout labeled Last } \\
\text { Update Method } \\
\text { Note: The readout labeled Last Update Method will } \\
\text { change to poll when next poll is taken. } \\
\text { Note: An alarm could be generated if the reading for } \\
\text { the sensor is an alarm range. } \\
\text { Note: the current Reading may or may not change } \\
\text { depending if the value being read has changed. }\end{array}$} & \\
\hline 4. & $\begin{array}{l}\text { Wait until the next } \\
\text { time the sensor is } \\
\text { polled. } \\
\text { Note: Not Valid for } \\
\text { SACS_LEVEL Sensors } \\
\text { at this time. }\end{array}$ & \multicolumn{2}{|c|}{$\begin{array}{l}\text { Verify the following: } \\
\text { - The date and time displayed in the Readout Last } \\
\text { Good Reading At is updated. } \\
\text { - Reading displayed in the Current Reading is } \\
\text { updated. } \\
\text { - POLL is displayed in the readout labeled Last } \\
\text { Update Method } \\
\text { Note: An alarm could be generated if the reading for } \\
\text { the sensor is an alarm range. } \\
\text { Note: the current Reading may or may not change } \\
\text { depending if the value being read has changed. }\end{array}$} & \\
\hline 5. & $\begin{array}{l}\text { Using the emulator } \\
\text { change the value that } \\
\text { is read for the sensor. }\end{array}$ & \multicolumn{2}{|c|}{$\begin{array}{l}\text { Verify the following: } \\
\text { - The date and time displayed in the Readout Last } \\
\text { Good Reading At is updated. } \\
\text { - Reading displayed in the Current Reading is } \\
\text { updated to the value issued by the emulator. }\end{array}$} & \\
\hline
\end{tabular}


HNF-3967, Rev. 3

\begin{tabular}{|c|c|c|c|}
\hline Step & Perform & Expected Result & Initial \\
\hline & $\begin{array}{l}\text { button. } \\
\text { Wait for the } \\
\text { workspace to be } \\
\text { updated } \\
\text { (approximately } 5 \\
\text { seconds). }\end{array}$ & $\begin{array}{l}\text { RPC is displayed in the readout labeled Last } \\
\text { Update Method } \\
\text { Note: The readout labeled Last Update Method will } \\
\text { change to poll when next poll is taken. } \\
\text { Note: An alarm could be generated if the reading for } \\
\text { the sensor is an alarm range. }\end{array}$ & \\
\hline 6. & $\begin{array}{l}\text { Wait until the next } \\
\text { time the sensor is } \\
\text { polled. }\end{array}$ & $\begin{array}{l}\text { Verify the following: } \\
\text { The date and time displayed in the Readout Last } \\
\text { Good Reading At is updated. } \\
\text { - Reading displayed in the Current Reading is } \\
\text { updated. } \\
\text { - POLL is displayed in the readout labeled Last } \\
\text { Update Method }\end{array}$ & \\
\hline 7. & $\begin{array}{l}\text { Click on the Print } \\
\text { button. }\end{array}$ & Verify the Sensor Details workspace is printed. & \\
\hline 8. & $\begin{array}{l}\text { Click on the Hide } \\
\text { button }\end{array}$ & Verify the Sensor Details workspace disappears. & \\
\hline 9. & $\begin{array}{l}\text { Select a continuous } \\
\text { sensor at random that } \\
\text { has point processing } \\
\text { disabled. } \\
\text { Display the sensor } \\
\text { details for the chosen } \\
\text { sensor. }\end{array}$ & $\begin{array}{l}\text { Verify the Update button (labeled U in the upper } \\
\text { right corner of the workspace) is not displayed. }\end{array}$ & \\
\hline
\end{tabular}

\subsubsection{Operation of Sensor History}

\begin{tabular}{|l|l|l|l|}
\hline Step & \multicolumn{1}{|c|}{ Perform } & \multicolumn{1}{c|}{ Expected Result } & Initial \\
\hline 1. & $\begin{array}{l}\text { Select a continuous sensor } \\
\text { at random that has history. } \\
\text { Display the individual } \\
\text { sensor trend chart for the } \\
\text { chosen sensor. }\end{array}$ & $\begin{array}{l}\text { Verify the trend chart is displayed and the tag } \\
\text { name is displayed above the trend chart }\end{array}$ & \\
\hline 2. & $\begin{array}{l}\text { Click on the trend chart. } \\
\text { nellowing: }\end{array}$ & $\begin{array}{l}\text { Verify the History Table is displayed with the } \\
\text { following }\end{array}$ & \\
& $\begin{array}{l}\text { - Hide }(X) \text { button } \\
\text { Print }(P) \text { button } \\
\text { Sensor tag name at top of workspace }\end{array}$ & \\
\hline
\end{tabular}


HNF-3967, Rev. 3

\begin{tabular}{|c|c|c|c|}
\hline Step & Perform & Expected Result & Initial \\
\hline & & 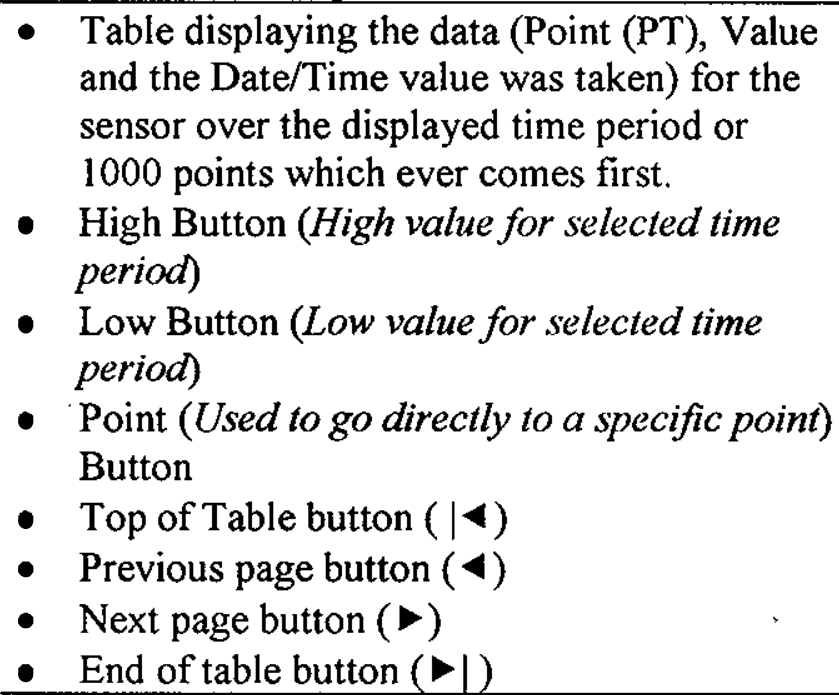 & \\
\hline 3. & Click on the High button & $\begin{array}{l}\text { Verify the position of the table displayed } \\
\text { contains the sensor point with the highest value. }\end{array}$ & \\
\hline 4. & Click on the Low button & $\begin{array}{l}\text { Verify the position of the table displayed } \\
\text { contains the sensor point with the lowest value. }\end{array}$ & \\
\hline 5. & $\begin{array}{l}\text { Chose a sensor point at } \\
\text { random. } \\
\text { Enter this point in the text } \\
\text { box associated with the } \\
\text { Point button. } \\
\text { Click on the Point button. }\end{array}$ & $\begin{array}{l}\text { Verify the position of the table displayed } \\
\text { contains the sensor point chosen. }\end{array}$ & \\
\hline 6. & $\begin{array}{l}\text { Click on the top of table } \\
\text { button }(\mid \triangleleft) \text {. }\end{array}$ & $\begin{array}{l}\text { Verify that the portion of the table displayed is } \\
\text { the first page in the table. }\end{array}$ & \\
\hline 7. & $\begin{array}{l}\text { Click on the end of table } \\
\text { button }(\vee \mid) \text {. }\end{array}$ & $\begin{array}{l}\text { Verify the portion of the table displayed is the } \\
\text { last page in the table. }\end{array}$ & \\
\hline 8. & $\begin{array}{l}\text { Click the previous page } \\
\text { button }(\varangle)\end{array}$ & $\begin{array}{l}\text { Verify the portion of the table displayed is the } \\
\text { previous page. }\end{array}$ & \\
\hline 9. & $\begin{array}{l}\text { Click the next page button } \\
(\bullet)\end{array}$ & $\begin{array}{l}\text { Verify the portion of the table displayed is the } \\
\text { next page. }\end{array}$ & \\
\hline 10. & Click on the Print button. & Verify the Sensor History workspace is printed. & \\
\hline 11. & Click on the table. & $\begin{array}{l}\text { Verify the history details workspace is displayed } \\
\text { with the following information: } \\
\text { - Total Point Count (signifies the total number } \\
\text { of points in history) } \\
\text { - Time Interval Point Count (signifies the } \\
\text { number of points display in history table and } \\
\text { trend chart for the selected time period) } \\
\text { - High Point Number }\end{array}$ & \\
\hline
\end{tabular}


HNF-3967, Rev. 3

\begin{tabular}{|c|c|c|c|}
\hline Step & Perform & Expected Result & Initial \\
\hline & & $\begin{array}{l}\text { - High Value } \\
\text { - } \text { High Date/Time } \\
\text { - Low Point Number } \\
\text { - Low Value } \\
\text { - } \text { Low Date/Time } \\
\text { - } 1 \text { hour } \\
\text { - } 8 \text { hours } \\
\text { - } 24 \text { hours } \\
\text { - } 7 \text { days } \\
\text { - } 31 \text { days }\end{array}$ & \\
\hline 12. & $\begin{array}{l}\text { Select a time interval at } \\
\text { random. }\end{array}$ & $\begin{array}{l}\text { Verify the following workspaces are updated: } \\
\text { - Individual Sensor Trend Chart } \\
\text { - History Table } \\
\text { - History Details }\end{array}$ & \\
\hline 13. & Click on the Print button. & Verify the History Details workspace is printed. & \\
\hline 14. & $\begin{array}{l}\text { Click on the Hide button } \\
\text { for the Individual Sensor } \\
\text { Trend workspace. }\end{array}$ & $\begin{array}{l}\text { Verify the following workspaces disappear: } \\
\text { - Individual Sensor Trend Chart } \\
\text { - History Table } \\
\text { - History Details }\end{array}$ & \\
\hline
\end{tabular}

\subsubsection{Operation of User Selectable trends}

This section describes the test cases for the individual selectable trends.

Note: User selectable sensor trends cannot be performed in a Telewindows ${ }^{\circ}$ session.

\begin{tabular}{|c|c|c|c|}
\hline Step & Perform & Expected Result & Initial \\
\hline 1. & $\begin{array}{l}\text { Click any enabled Tank } \\
\text { Icon in the Hanford Tank } \\
\text { Farm Facilities. (The icon } \\
\text { will not be gray.) } \\
\text { Click on a USER } \\
\text { SELECTABLE TRENDS } \\
\text { button. (located at the } \\
\text { bottom of the Tank Status } \\
\text { workspace.) }\end{array}$ & $\begin{array}{l}\text { Verify that the USER SELECTABLE TRENDS } \\
\text { workspace appears and contains the following. } \\
\text { - Title (identifying what Tank trend is } \\
\text { associated with) } \\
\text { - Trend graph or chart. } \\
\text { - HIDE WINDOW button (with an } x \text { as a } \\
\text { symbol) } \\
\text { - SHRINK WINDOW button (an } \nabla \text { as a } \\
\text { symbol) } \\
\text { - EXPAND WINDOW button (an } \Delta \text { as a } \\
\text { symbol) } \\
\text { PRINT SCREEN button }\end{array}$ & \\
\hline
\end{tabular}


HNF-3967, Rev. 3

\begin{tabular}{|c|c|c|c|}
\hline Step & Perform & Expected Result & Initial \\
\hline & . & $\begin{array}{l}\text { - UPDATE GRAPH button (below the } \\
\text { graph). } \\
\text { - } \quad \text { SELECT TIME INTERVAL OPTIONS } \\
\text { - } 8 \text { hour } \\
\text { - } 24 \text { hours } \\
\text { - } 7 \text { days } \\
\text { - } 31 \text { days. } \\
\text { - List of sensors associated with user } \\
\text { selectable trend with the following } \\
\text { - Check box (indicates if sensor is displayed } \\
\text { on graph/chart) } \\
\text { - Sensor symbol (identifies sensor on } \\
\text { graph/chart) } \\
\text { Current, Low, and High readings (based on } \\
\text { the SELECT TIME INTERVAL chosen.) } \\
\text { - Sensor Reading Description containing the } \\
\text { following information } \\
\text { - Type of readings (i.e. temperature) } \\
\text { - UnELEC Timits of readings (i.e. Degrees Fahrenheit) } \\
\text { Date and Time }\end{array}$ & \\
\hline 2 . & $\begin{array}{l}\text { Click on the UPDATE } \\
\text { GRAPH button }\end{array}$ & $\begin{array}{l}\text { Verify the Graph/Chart has the following: } \\
\text { - The current value for each sensor on the } \\
\text { trend graph approximates the current value } \\
\text { on the digital display. } \\
\text { - The values line matches the symbol for } \\
\text { each sensor. } \\
\text { - Trend graph label (below the x-axis of the } \\
\text { graph) reads: } \\
\text { "TANK xx-yyy SELECTED SENSORS } \\
\text { INDICATED BY X" } \\
\text { Where "xx-yyy" represents the name of the } \\
\text { tank. } \\
\text { The time scale of the horizontal time axis is } \\
\text { based on the SELECT TIME INTERVAL } \\
\text { chosen. }\end{array}$ & \\
\hline \multicolumn{4}{|c|}{ 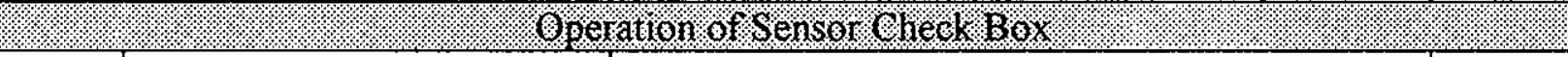 } \\
\hline 3. & $\begin{array}{l}\text { Click on the box of any } \\
\text { sensor that contains an } \mathrm{X} \text {. }\end{array}$ & Verify that the $\mathrm{X}$ is removed from the box. & \\
\hline 4. & Click on the UPDATE & Verify the trend graph displays only lines for & \\
\hline
\end{tabular}




\section{Error}

An error occurred while processing this page. See the system log for more details. 
Prior to performing this test case set up sensors that have not reported a value within the current day. (Note: Emulator is required to get the quality status of sensors equal to good. Also need a large amount of sensors to display continuous/discrete and SACS level sensors)

\begin{tabular}{|c|c|c|c|}
\hline Step & Perform & Expected Result & Initial \\
\hline 1. & $\begin{array}{l}\text { Select the Suspect Sensor } \\
\text { Report button from the } \\
\text { Reports Menu workspace. }\end{array}$ & 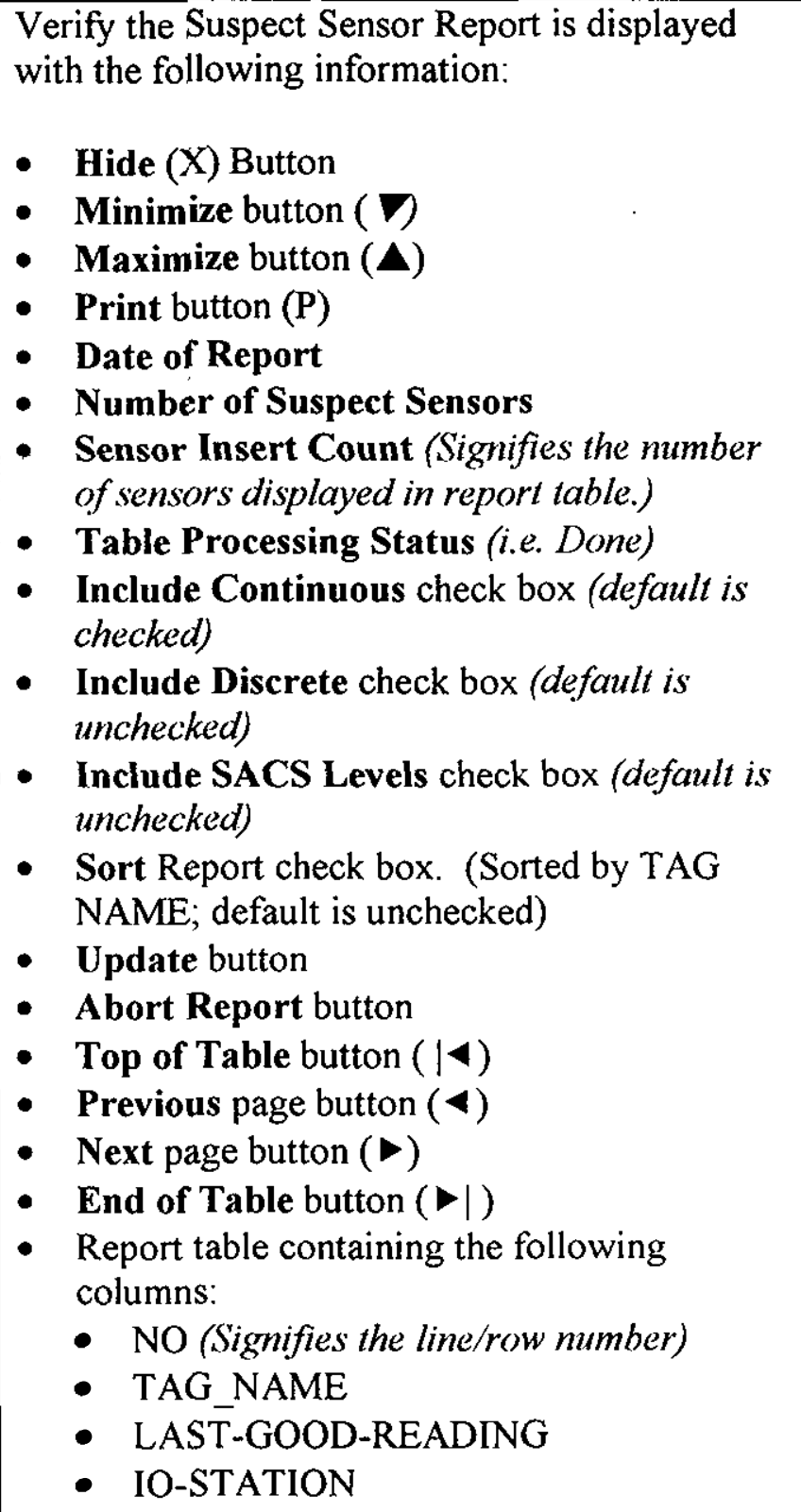 & \\
\hline 2. & Click the Update button & $\begin{array}{l}\text { Verify the following: } \\
\text { - Report Table is updated } \\
\text { - Date of Report is updated. } \\
\text { - Sensor Insert Count is equal to the number of } \\
\text { - sensor in the table. } \\
\text { - Number of Sensor is equal to the Sensor }\end{array}$ & \\
\hline
\end{tabular}


HNF-3967, Rev. 3

\begin{tabular}{|c|c|c|c|}
\hline Step & Perform & Expected Result & Initial \\
\hline & & $\begin{array}{l}\text { Insert Count. } \\
\text { Note the Table Processing Status will change } \\
\text { from Done to Active back to Done. }\end{array}$ & \\
\hline 3. & $\begin{array}{l}\text { Click each combination of } \\
\text { the following check boxes. } \\
\text { - Include Continuous } \\
\text { - Include Discrete } \\
\text { - Include SACS Levels } \\
\text { Click the Update button. }\end{array}$ & $\begin{array}{l}\text { Verify the following: } \\
\text { - The appropriate check box (s) is checked. } \\
\text { - Report Table is updated with the appropriate } \\
\text { data } \\
\text { - Date of Report is updated. } \\
\text { - Sensor Insert Count is equal to the number of } \\
\text { sensor in the table. } \\
\text { - Number of Sensor is equal to the Sensor } \\
\text { Insert Count. } \\
\text { Note the Table Processing Status will change } \\
\text { from Done to Active back to Done. }\end{array}$ & \\
\hline 4. & $\begin{array}{l}\text { Click the Sort check box so } \\
\text { the box is checked. } \\
\text { Click the Update button. }\end{array}$ & $\begin{array}{l}\text { Verify the following: } \\
\text { - Sort check box is checked. } \\
\text { - Report Table is updated and the data is } \\
\text { sorted by TAG_NAME. } \\
\text { - Date of Report is updated } \\
\text { - Sensor Insert Count is equal to the number of } \\
\text { sensor in the table. } \\
\text { - Number of Sensor is equal to the Sensor } \\
\text { Insert Count. } \\
\text { Note the Table Processing Status will change } \\
\text { from Done to Active back to Done. }\end{array}$ & \\
\hline 5 . & $\begin{array}{l}\text { Click the Sort check box so } \\
\text { the box is unchecked. } \\
\text { Click the Update button. }\end{array}$ & $\begin{array}{l}\text { Verify the following: } \\
\text { - Sort check box is unchecked. } \\
\text { - Report Table is updated (Note the data may } \\
\text { or may not be sorted depending on how the } \\
\text { data was read in). } \\
\text { - Date of Report is updated } \\
\text { - Sensor Insert Count is equal to the number of } \\
\text { sensor in the table. } \\
\text { - Number of Sensor is equal to the Sensor } \\
\text { Insert Count. } \\
\text { Note the Table Processing Status will change } \\
\text { from Done to Active back to Done }\end{array}$ & \\
\hline
\end{tabular}


HNF-3967, Rev. 3

\begin{tabular}{|c|c|c|c|}
\hline Step & Perform & Expected Result & Initial \\
\hline 6. & $\begin{array}{l}\text { Click the Update button } \\
\text { immediately followed by } \\
\text { the Abort Report button. }\end{array}$ & $\begin{array}{l}\text { Verify the following: } \\
\text { - Date of Report is updated } \\
\text { - Sensor Insert Count is equal to the number of } \\
\text { sensor in the table. } \\
\text { - Number of Sensor is not equal to the Sensor } \\
\text { Insert Count. } \\
\text { - Table Processing Status changes to Abort } \\
\text { Note the Table Processing Status will change } \\
\text { from Done to Active to Abort }\end{array}$ & \\
\hline 7. & $\begin{array}{l}\text { Click on the Title block of } \\
\text { the report table. }\end{array}$ & $\begin{array}{l}\text { Verify the help workspace for this report is } \\
\text { displayed. }\end{array}$ & \\
\hline 8. & Click the Maximize button. & Verify the workspace is maximized. & \\
\hline 9. & Click the Minimize button & Verify the workspace is minimized & \\
\hline 10. & $\begin{array}{l}\text { Click on the Top of report } \\
\text { button }(1-) \text {. }\end{array}$ & $\begin{array}{l}\text { Verify that the portion of the report displayed is } \\
\text { the first page in the report. (Note: Report may fit } \\
\text { on one page and therefore no change is seen.) }\end{array}$ & \\
\hline 11. & $\begin{array}{l}\text { Click on the End of report } \\
\text { button }(\triangleright 1) \text {. }\end{array}$ & $\begin{array}{l}\text { Verify the portion of the report displayed is the } \\
\text { last page in the report. (Note: Report may fit on } \\
\text { one page and therefore no change is seen.) }\end{array}$ & \\
\hline 12. & $\begin{array}{l}\text { Click the Previous page } \\
\text { button ( } 4)\end{array}$ & $\begin{array}{l}\text { Verify the portion of the report displayed is the } \\
\text { previous page. (Note: Report may fit on one } \\
\text { page and therefore no change is seen.) }\end{array}$ & \\
\hline 13. & $\begin{array}{l}\text { Click the Next page button } \\
(\triangleright) \text {. }\end{array}$ & $\begin{array}{l}\text { Verify the portion of the report displayed is the } \\
\text { next page. (Note: Report may fit on one page } \\
\text { and therefore no change is seen.) }\end{array}$ & \\
\hline 14. & $\begin{array}{l}\text { Click on the Print button } \\
\text { (P). (Note: Not functional } \\
\text { on the remote stations at } \\
\text { this time.) }\end{array}$ & $\begin{array}{l}\text { Verify the portion of the workspace displayed is } \\
\text { printed to the printer. }\end{array}$ & \\
\hline 15. & $\begin{array}{l}\text { Click on the Hide button } \\
\text { (X). }\end{array}$ & Verify the report workspace is hidden. & \\
\hline
\end{tabular}

\subsubsection{Suspect IO-Station Report}

Prior to performing this test case set up IO stations that are not reporting.

\begin{tabular}{|c|c|c|c|}
\hline Step & Perform & Expected Result & Initial \\
\hline 1. & $\begin{array}{l}\text { Select the Suspect I/O - } \\
\text { Station Report button } \\
\text { from the Reports Menu } \\
\text { workspace. }\end{array}$ & $\begin{array}{l}\text { Verify the Suspect IO-Station Report is } \\
\text { displayed with the following information: } \\
\text { - Hide }(\mathrm{X}) \text { Button } \\
\text { - Minimize button ( } \nabla\end{array}$ & \\
\hline
\end{tabular}


HNF-3967, Rev. 3

\begin{tabular}{|c|c|c|c|}
\hline Step & Perform & Expected Result & Initial \\
\hline & & 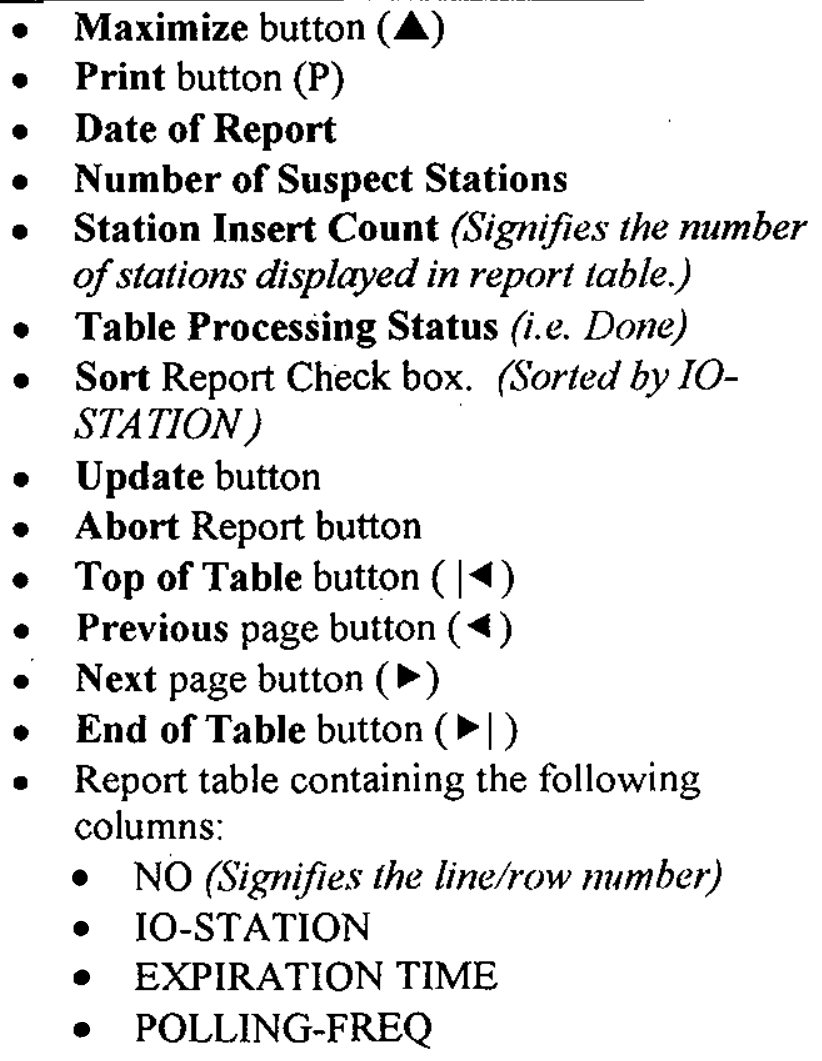 & \\
\hline 2. & Click the Update button & $\begin{array}{l}\text { Verify the following: } \\
\text { - Report Table is updated } \\
\text { - Date of Report is updated. } \\
\text { Station Insert Count is equal to the number } \\
\text { - Number in the table. } \\
\text { Insert Count. } \\
\text { Note the Table Processing Status will change } \\
\text { from Done to Active back to Done }\end{array}$ & \\
\hline 3. & $\begin{array}{l}\text { Click the Sort check box so } \\
\text { it is checked. } \\
\text { Click the Update button. }\end{array}$ & $\begin{array}{l}\text { Verify the following: } \\
\text { - Sort check box is checked. } \\
\text { - Report Table is updated and the data is } \\
\text { sorted by lO-STATION. } \\
\text { - Date of Report is updated } \\
\text { - Station Insert Count is equal to the number } \\
\text { of station in the table. } \\
\text { - Number of Station is equal to the Station } \\
\text { Insert Count. } \\
\text { Note the Table Processing Status will change }\end{array}$ & \\
\hline
\end{tabular}


HNF-3967, Rev. 3

\begin{tabular}{|c|c|c|c|}
\hline Step & Perform & Expected Result & Initial \\
\hline & & from Done to Active back to Done & \\
\hline 4. & $\begin{array}{l}\text { Click the Sort check box so } \\
\text { it is unchecked. } \\
\text { Click the Update button. }\end{array}$ & $\begin{array}{l}\text { Verify the following: } \\
\text { - Sort check box is unchecked. } \\
\text { - Report Table is updated (Note the data may } \\
\text { or maynot be sorted depending on how the } \\
\text { data was read in). } \\
\text { - Date of Report is updated } \\
\text { - Station Insert Count is equal to the number } \\
\text { of stations in the table. } \\
\text { - Number of Stations is equal to the Station } \\
\text { Insert Count. } \\
\text { Note the Table Processing Status will change } \\
\text { from Done to Active back to Done }\end{array}$ & \\
\hline 5. & $\begin{array}{l}\text { Click the Update button } \\
\text { immediately followed by } \\
\text { the Abort Report. }\end{array}$ & $\begin{array}{l}\text { Verify the following: } \\
\text { - Date of Report is updated } \\
\text { - Table Processing Status changes to Abort } \\
\text { - Station Insert Count is equal to the number } \\
\text { of station in the table. } \\
\text { - Number of Sensor is not equal to the Sensor } \\
\text { Insert Count. } \\
\text { Note the Table Processing Status will change } \\
\text { from Done to Active to Abort }\end{array}$ & \\
\hline 6. & $\begin{array}{l}\text { Click on the Title block of } \\
\text { the report table. }\end{array}$ & $\begin{array}{l}\text { Verify the help workspace for this report is } \\
\text { displayed. }\end{array}$ & \\
\hline 7. & Click the Maximize button. & Verify the workspace is maximized. & \\
\hline 8. & Click the Minimize button & Verify the workspace is minimized & \\
\hline 9. & $\begin{array}{l}\text { Click on the Top of report } \\
\text { button }(\mid \varangle) \text {. }\end{array}$ & $\begin{array}{l}\text { Verify that the portion of the report displayed is } \\
\text { the first page in the report. (Note: Report may fit } \\
\text { on one page and therefore no change is seen.) }\end{array}$ & \\
\hline 10. & $\begin{array}{l}\text { Click on the End of report } \\
\text { button }(\bullet \mid) \text {. }\end{array}$ & $\begin{array}{l}\text { Verify the portion of the report displayed is the } \\
\text { last page in the report. (Note: Report may fit on } \\
\text { one page and therefore no change is seen.) }\end{array}$ & \\
\hline 11. & $\begin{array}{l}\text { Click the Previous page } \\
\text { button ( } 1 \text { ) }\end{array}$ & $\begin{array}{l}\text { Verify the portion of the report displayed is the } \\
\text { previous page. (Note: Report may fit on one } \\
\text { page and therefore no change is seen.) }\end{array}$ & \\
\hline 12. & $\begin{array}{l}\text { Click the Next page } \\
\text { button }(\bullet)\end{array}$ & $\begin{array}{l}\text { Verify the portion of the report displayed is the } \\
\text { next page. (Note: Report may fit on one page } \\
\text { and therefore no change is seen.) }\end{array}$ & \\
\hline 13. & $\begin{array}{l}\text { Click on the Print button } \\
\text { (P). (Note: Not functional }\end{array}$ & $\begin{array}{l}\text { Verify the portion of the workspace displayed is } \\
\text { printed to the printer. }\end{array}$ & \\
\hline
\end{tabular}


HNF-3967, Rev. 3

\begin{tabular}{|c|c|c|c|}
\hline Step & Perform & Expected Result & Initial \\
\hline & $\begin{array}{l}\text { on the remote stations at } \\
\text { this time.) }\end{array}$ & & \\
\hline 14. & Click on a row in the table. & $\begin{array}{l}\text { Verify the Suspect IO-Station Detail Report is } \\
\text { displayed with the following information: } \\
\text { - Hide (X) Button } \\
\text { - Minimize button ( } \nabla \\
\text { - Maximize button (A) } \\
\text { - Print button (P) } \\
\text { - Date of Report } \\
\text { - Number of Suspect Sensors } \\
\text { - Sensor Insert Count (Signifies the number } \\
\text { of sensors displayed in report table that are } \\
\text { associated with the selected station.) } \\
\text { - Table Processing Status (i.e. Done) } \\
\text { - Sort Report Check box. (Sorted by IO- } \\
\text { STATION) } \\
\text { - Update button } \\
\text { - Abort Report button } \\
\text { - Top of Table button ( | }) \\
\text { - Previous page button ( } 4 \text { ) } \\
\text { - Next page button ( } \text {-) } \\
\text { - End of Table button ( } 1 \text { ) } \\
\text { - Report table containing the following } \\
\text { columns: } \\
\text { - NO (Signifies the line/row mumber) } \\
\text { - TAG NAME } \\
\text { - LAST-GOOD-READING } \\
\text { - IOge and End of Table are included for future } \\
\text { use. There currently is no station that has more } \\
\text { than } 25 \text { (Table Size) sensors connected to it. } \\
\text { - }\end{array}$ & \\
\hline 15 . & Click the Update button & $\begin{array}{l}\text { Verify the following: } \\
\text { - Report Table is updated } \\
\text { - Date of Report is updated. } \\
\text { - Sensor Insert Count is equal to the number of } \\
\text { sensors in the table. } \\
\text { - Number of Sensors is equal to the Sensor } \\
\text { Insert Count. } \\
\text { Note the Table Processing Status will change } \\
\text { from Done to Active back to Done }\end{array}$ & \\
\hline
\end{tabular}


HNF-3967, Rev. 3

\begin{tabular}{|c|c|c|c|}
\hline Step & Perform & Expected Result & Initial \\
\hline 16. & $\begin{array}{l}\text { Click the Sort check box so } \\
\text { it is checked. } \\
\text { Click the Update button. }\end{array}$ & $\begin{array}{l}\text { Verify the following: } \\
\text { - Sort check box is checked. } \\
\text { - Report Table is updated and the data is } \\
\text { sorted by TAG_NAME. } \\
\text { - Date of Report is updated } \\
\text { - Sensor Insert Count is equal to the number of } \\
\text { sensor in the table. } \\
\text { - Number of Sensor is equal to the Sensor } \\
\text { Insert Count. } \\
\text { Note the Table Processing Status will change } \\
\text { from Done to Active back to Done }\end{array}$ & \\
\hline 17. & $\begin{array}{l}\text { Click the Sort check box so } \\
\text { it is unchecked. } \\
\text { Click the Update button. }\end{array}$ & $\begin{array}{l}\text { Verify the following: } \\
\text { - Sort check box is unchecked. } \\
\text { - Report Table is updated (Note the data may } \\
\text { or may not be sorted depending on how the } \\
\text { data was read in). } \\
\text { - Date of Report is updated } \\
\text { - Sensor Insert Count is equal to the number of } \\
\text { stations in the table. } \\
\text { - Number of Sensor is equal to the Station } \\
\text { Insert Count. } \\
\text { Note the Table Processing Status will change } \\
\text { from Done to Active back to Done }\end{array}$ & \\
\hline 18. & $\begin{array}{l}\text { Click the Update button } \\
\text { immediately followed by } \\
\text { the Abort Report. }\end{array}$ & $\begin{array}{l}\text { Verify the following: } \\
\text { - Date of Report is updated } \\
\text { - Table Processing Status changes to Abort } \\
\text { - Station Insert Count is equal to the number } \\
\text { of station in the table. } \\
\text { - Number of Sensor is not equal to the Sensor } \\
\text { Insert Count. } \\
\text { Note the Table Processing Status will change } \\
\text { from Done to Active to Abort }\end{array}$ & \\
\hline 19. & Click the Maximize button. & Verify the workspace is maximized. & \\
\hline 20. & Click the Minimize button & Verify the workspace is minimized & \\
\hline 21. & $\begin{array}{l}\text { Click on the Print button } \\
\text { (P). (Note: Not functional } \\
\text { on the remote stations at } \\
\text { this time.) }\end{array}$ & $\begin{array}{l}\text { Verify the portion of the workspace displayed is } \\
\text { printed to the printer. }\end{array}$ & \\
\hline
\end{tabular}


HNF-3967, Rev. 3

\begin{tabular}{|c|l|l|l|}
\hline Step & \multicolumn{1}{|c|}{ Perform } & \multicolumn{1}{c|}{ Expected Result } & Initial \\
\hline 22. & $\begin{array}{l}\text { Click on the Hide (X) } \\
\text { button on the Suspect IO- } \\
\text { Station Detail Report } \\
\text { workspace. }\end{array}$ & Verify the report workspace is hidden. & \\
\hline 23. & $\begin{array}{l}\text { Click on the Hide (X) } \\
\text { button on the Suspect IO- } \\
\text { Station Report workspace. }\end{array}$ & Verify the report workspace is hidden. & \\
\hline
\end{tabular}

\subsubsection{Unknown Sensor Report}

Prior to performing this test case set the quality status of a few sensors to unknown.

\begin{tabular}{|c|c|c|c|}
\hline Step & Perform & Expected Result & Initial \\
\hline 24 . & $\begin{array}{l}\text { Select the Unknown } \\
\text { Sensor Report button } \\
\text { from the Reports Menu } \\
\text { workspace. }\end{array}$ & 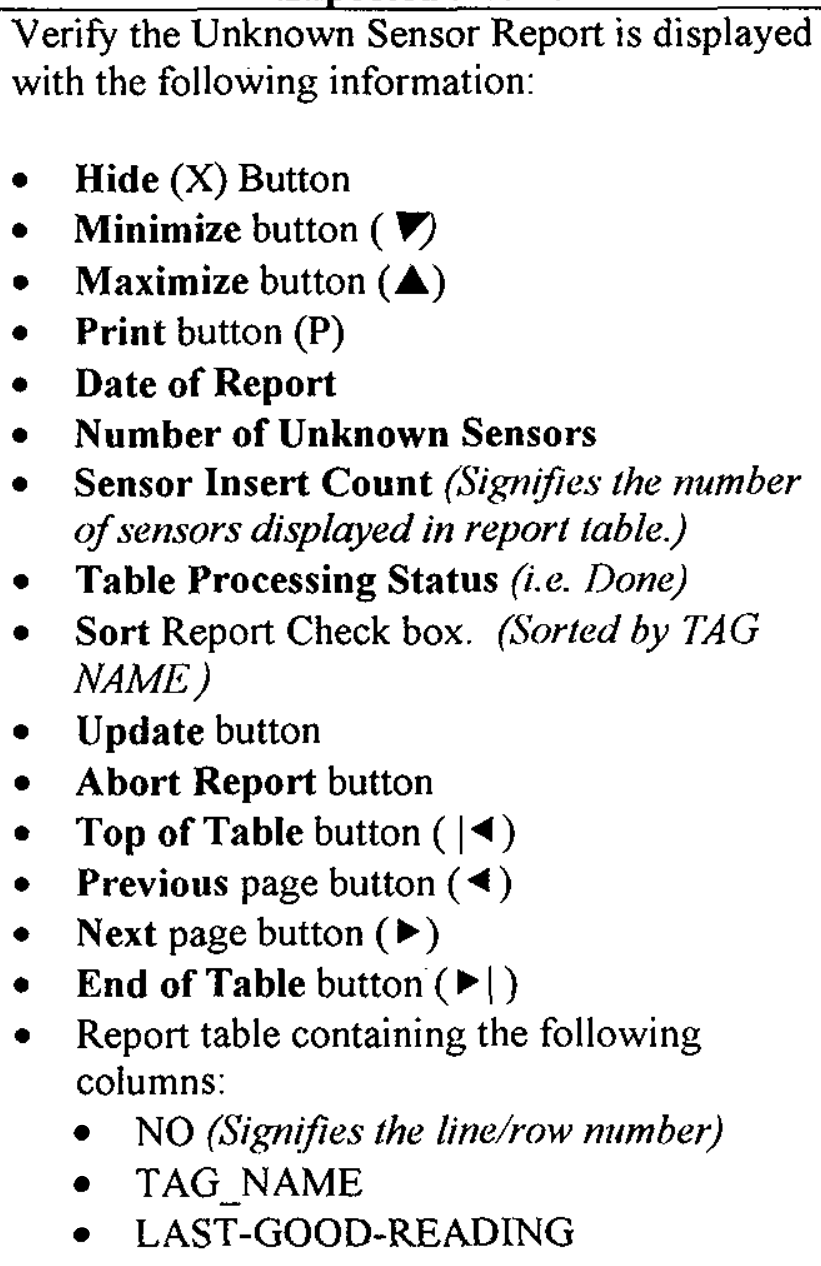 & \\
\hline 25. & Click the Update button & $\begin{array}{l}\text { Verify the following: } \\
\text { - Report Table is updated } \\
\text { - Date of Report is updated. }\end{array}$ & \\
\hline 26. & Click the Sort check box so & Verify the following: & \\
\hline
\end{tabular}


HNF-3967, Rev. 3

\begin{tabular}{|c|c|c|c|}
\hline Step & Perform & Expected Result & Initial \\
\hline & $\begin{array}{l}\text { it is checked. } \\
\text { Click the Update button. }\end{array}$ & $\begin{array}{l}\text { - Sort check box is checked. } \\
\text { - Report Table is updated and the data is } \\
\text { sorted by TAG_NAME. } \\
\text { - Date of Report is updated } \\
\text { - Sensor Insert Count is equal to the number of } \\
\text { sensor in the table. } \\
\text { - Number of Sensor is equal to the Sensor } \\
\text { Insert Count. } \\
\text { Note the Table Processing Status will change } \\
\text { from Done to Active back to Done }\end{array}$ & \\
\hline 27. & $\begin{array}{l}\text { Click the Sort check box so } \\
\text { it is unchecked. } \\
\text { Click the Update button. }\end{array}$ & $\begin{array}{l}\text { Verify the following: } \\
\text { - Sort check box is unchecked. } \\
\text { - Report Table is updated (Note the data may } \\
\text { or maynot be sorted depending on how the } \\
\text { data was read in). } \\
\text { - Date of Report is updated } \\
\text { - Sensor Insert Count is equal to the number of } \\
\text { - Nensor in the table. } \\
\text { Insert Count. } \\
\text { Note the Table Processing Status will change } \\
\text { from Done to Active back to Done }\end{array}$ & \\
\hline 28. & $\begin{array}{l}\text { Click the Update button } \\
\text { immediately followed by } \\
\text { the Abort Report. }\end{array}$ & $\begin{array}{l}\text { Verify the following: } \\
\text { - Date of Report is updated } \\
\text { - Table Processing Status changes to Abort } \\
\text { - Sensor Insert Count is equal to the number of } \\
\text { sensor in the table. } \\
\text { - Number of Sensor is not equal to the Sensor } \\
\text { Insert Count. } \\
\text { Note the Table Processing Status will change } \\
\text { from Done to Active to Abort }\end{array}$ & \\
\hline 29. & $\begin{array}{l}\text { Click on the Title block of } \\
\text { the report table. }\end{array}$ & $\begin{array}{l}\text { Verify the help workspace for this report is } \\
\text { displayed. }\end{array}$ & \\
\hline 30. & Click the Maximize button. & Verify the workspace is maximized. & \\
\hline 31. & Click the Minimize button & Verify the workspace is minimized & \\
\hline 32. & $\begin{array}{l}\text { Click on the Top of report } \\
\text { button }(\mid \varangle) \text {. }\end{array}$ & $\begin{array}{l}\text { Verify that the portion of the report displayed is } \\
\text { the first page in the report. (Note: Report may fit } \\
\text { on one page and therefore no change is seen.) }\end{array}$ & \\
\hline
\end{tabular}




\begin{tabular}{|c|c|c|c|}
\hline Step & Perform & Expected Result & Initial \\
\hline 33. & $\begin{array}{l}\text { Click on the End of report } \\
\text { button }(\neg \mid) \text {. }\end{array}$ & $\begin{array}{l}\text { Verify the portion of the report displayed is the } \\
\text { last page in the report. (Note: Report may fit on } \\
\text { one page and therefore no change is seen.) }\end{array}$ & \\
\hline 34. & $\begin{array}{l}\text { Click the Previous page } \\
\text { button ( } 4)\end{array}$ & $\begin{array}{l}\text { Verify the portion of the report displayed is the } \\
\text { previous page. (Note: Report may fit on one } \\
\text { page and therefore no change is seen.) }\end{array}$ & \\
\hline 35. & $\begin{array}{l}\text { Click the Next page } \\
\text { button( } \triangleright) \text {. }\end{array}$ & $\begin{array}{l}\text { Verify the portion of the report displayed is the } \\
\text { next page. (Note: Report may fit on one page } \\
\text { and therefore no change is seen.) }\end{array}$ & \\
\hline 36. & $\begin{array}{l}\text { Click on the Print button } \\
\text { (P). Note: Not functional } \\
\text { on the remote stations at } \\
\text { this time.) }\end{array}$ & $\begin{array}{l}\text { Verify the portion of the workspace displayed is } \\
\text { printed to the printer. }\end{array}$ & \\
\hline 37. & $\begin{array}{l}\text { Click on the Hide button } \\
\text { (X). }\end{array}$ & Verify the report workspace is hidden. & \\
\hline
\end{tabular}

\subsection{EXTERNAL INTERFACES}

\subsubsection{Acromag ${ }^{\mathrm{TM}}$}

The tests in this section require the use of an Acromagrm emulator. The test should be run on the development machine.

\subsubsection{Conversion of Acromag ${ }^{\mathrm{TM}}$ Temperature Output to Engineering Units}

\begin{tabular}{|c|c|c|c|}
\hline Step & Perform & Expected Result & Initial \\
\hline 1. & $\begin{array}{l}\text { From the tag list, choose } \\
\text { an Acromag }{ }^{\mathrm{TM}} \text { temperature } \\
\text { sensor at random. } \\
\text { Display the Sensor Details } \\
\text { for the chosen sensor. } \\
\text { Press the Update button } \\
\text { then use the Formula } \\
\text { expression and Raw Value } \\
\text { to calculate the current } \\
\text { reading for the sensor. }\end{array}$ & Write the value here & \\
\hline 2. & $\begin{array}{l}\text { Compare the Current } \\
\text { Reading with the reading } \\
\text { in Step } 1 .\end{array}$ & Verify that the readings are the same. & \\
\hline
\end{tabular}


HNF-3967, Rev. 3

\begin{tabular}{|l|l|l|l|}
\hline Step & \multicolumn{1}{|c|}{ Perform } & \multicolumn{1}{c|}{ Expected Result } & Initial \\
\hline 3. & $\begin{array}{l}\text { Display the history details } \\
\text { for this sensor. }\end{array}$ & $\begin{array}{l}\text { Verify that the value is displayed and matches } \\
\text { the value recorded in Step l. (Note: It is } \\
\text { possible for the value to be displayed more than } \\
\text { once in the history details if it crosses a limit } \\
\text { boundary.) }\end{array}$ & $\vdots$ \\
\hline
\end{tabular}

\subsubsection{Conversion of AcromagrM 4 to 20 ma Output to Engineering Units}

\begin{tabular}{|c|c|c|c|}
\hline Step & Perform & Expected Result & Initial \\
\hline 1. & $\begin{array}{l}\text { From the tag list, choose } \\
\text { an Acromag }{ }^{\mathrm{TM}} \text { non- } \\
\text { temperature sensor at } \\
\text { random, e.g., pressure, } \\
\text { flow, surface level, ... } \\
\text { Display the Sensor Details } \\
\text { for the chosen sensor. } \\
\text { Press the Update button } \\
\text { then use the Formula } \\
\text { expression and Raw Value } \\
\text { to calculate the current } \\
\text { reading for the sensor. }\end{array}$ & Write the value here & \\
\hline 2. & $\begin{array}{l}\text { Compare the Current } \\
\text { Reading with the reading } \\
\text { in Step 1. }\end{array}$ & Verify that the readings are the same. & \\
\hline 3. & $\begin{array}{l}\text { Display the history details } \\
\text { for this sensor. }\end{array}$ & $\begin{array}{l}\text { Verify that the value is displayed and matches } \\
\text { the value recorded in Step } 1 \text {. (Note: It is } \\
\text { possible for the value to be displayed more than } \\
\text { once in the history details if it crosses a limit } \\
\text { boundary.) }\end{array}$ & \\
\hline
\end{tabular}

\subsubsection{Conversion of AcromagTM Digital Data to Discrete States}

The Acromag ${ }^{\mathrm{TM}}$ emulator does not directly support digital input for the Acromag ${ }^{\mathrm{TM}}$. A digital value of 0 may be simulated with a temperature value of $32.0 \mathrm{~F}$. A digital 1 is simulated with a temperature of $32.18 \mathrm{~F}$. Any other value will be an unknown state.

\begin{tabular}{|c|c|c|c|}
\hline Step & Perform & Expected Result & Initial \\
\hline
\end{tabular}


HNF-3967, Rev. 3

\begin{tabular}{|l|l|l|l|}
\hline Step & \multicolumn{1}{|c|}{ Perform } & Initial \\
\hline 1. & $\begin{array}{l}\text { Using the tag list, choose } \\
\text { an enabled Acromagtm } \\
\text { digital sensor at random. } \\
\text { Use the emulator to } \\
\text { simulate a value of digital } \\
0 \text { for this sensor. } \\
\text { After an appropriate delay } \\
\text { for the TMACS to poll the } \\
\text { emulator for this sensor. } \\
\text { emse the emulator to } \\
\text { simulate a value of digital } \\
1 \text { for this sensor. } \\
\text { After an appropriate delay } \\
\text { for the TMACS to poll the } \\
\text { emulator for this sensor. }\end{array}$ & Verify that the sensor is alarm. & \\
\hline
\end{tabular}

\subsubsection{Enraf ${ }^{(k)}$}

The tests in this section require the use of an Enraf ${ }^{(0)}$ emulator. The test should be run on the development machine.

\subsubsection{Conversion of Enraf ${ }^{(\mathrm{k})}$ CIU Output to Engineering Units}

\begin{tabular}{|c|c|c|c|}
\hline Step & Perform & Expected Result & Initial \\
\hline 1. & $\begin{array}{l}\text { From the tag list, choose } \\
\text { an Enraf } \text { CIU sensor at } \\
\text { random. } \\
\text { Display the Sensor Details } \\
\text { for the chosen sensor. } \\
\text { Press the Update button } \\
\text { then use the Formula } \\
\text { expression and Raw Value } \\
\text { to calculate the current } \\
\text { reading for the sensor. }\end{array}$ & Write the value here & \\
\hline 2. & $\begin{array}{l}\text { Compare the Current } \\
\text { Reading with the reading } \\
\text { in Step 1. }\end{array}$ & Verify that the readings are the same. & \\
\hline 3. & $\begin{array}{l}\text { Display the history details } \\
\text { for this sensor. }\end{array}$ & $\begin{array}{l}\text { Verify that the value is displayed and matches } \\
\text { the value recorded in Step 1. (Note: It is } \\
\text { possible for the value to be displayed more than } \\
\text { once in the history details if it crosses a limit } \\
\text { boundary.) }\end{array}$ & \\
\hline
\end{tabular}


HNF-3967, Rev. 3

\subsubsection{Westronics ${ }^{(1)}$}

The tests in this section require the use of a Westronics ${ }^{\infty}$ emulator. The test should be run on the development machine.

\subsubsection{Conversion of Westronics ${ }^{\circledR}$ Temperature Output to Engineering Units}

\begin{tabular}{|c|c|c|c|}
\hline Step & Perform & Expected Result & Initial \\
\hline 1. & $\begin{array}{l}\text { From the tag list, choose a } \\
\text { Westronics }{ }^{\otimes} \text { temperature } \\
\text { sensor at random. } \\
\text { Display the Sensor Details } \\
\text { for the chosen sensor. } \\
\text { Press the Update button } \\
\text { then use the Formula } \\
\text { expression and Raw Value } \\
\text { to calculate the current } \\
\text { reading for the sensor. }\end{array}$ & Write the value here & \\
\hline 2. & $\begin{array}{l}\text { Compare the Current } \\
\text { Reading with the reading } \\
\text { in Step } 1 .\end{array}$ & Verify that the readings are the same. & \\
\hline 3. & $\begin{array}{l}\text { Display the history details } \\
\text { for this sensor. }\end{array}$ & $\begin{array}{l}\text { Verify that the value is displayed and matches } \\
\text { the value recorded in Step } 1 \text {. (Note: It is } \\
\text { possible for the value to be displayed more than } \\
\text { once in the history details if it crosses a limit } \\
\text { boundary.) }\end{array}$ & \\
\hline
\end{tabular}

\subsubsection{Panalarm}

The tests in this section require the use of a Panalarm ${ }^{\infty}$ emulator. The test should be run on the development machine. 
HNF-3967, Rev. 3

\subsubsection{Conversion of Panalarm ${ }^{\otimes}$ Output to Digital Data to Discrete States}

\begin{tabular}{|l|l|l|l|}
\hline Step & \multicolumn{1}{|c|}{ Perform } & \multicolumn{1}{c|}{ Expected Result } & Initial \\
\hline 1. & $\begin{array}{l}\text { Using the tag list, choose a } \\
\text { Panalarm } \\
\text { random. }\end{array}$ & Vensor at \\
$\begin{array}{l}\text { Use the emulator to } \\
\text { simulate a value of digital } \\
1 \text { for this sensor. } \\
\text { After an appropriate delay } \\
\text { for the TMACS to poll the } \\
\text { emulator for this sensor. }\end{array}$ & $\begin{array}{l}\text { Use the emulator to } \\
\text { simulate a value of digital } \\
\text { 0 for this sensor. } \\
\text { After an appropriate delay } \\
\text { for the TMACS to poll the } \\
\text { emulator for this sensor. }\end{array}$ & Verify that the sensor is reset. & \\
\hline 2. & Return to the main screen. & & \\
\hline 3. & & & \\
\hline
\end{tabular}

\subsubsection{SACS}

TMACS retrieves surface level data from SACS whenever TMACS starts and at 2000 every evening thereafter. The "last SACS reading" will be the last reading taken and marked good (the quality status was set to " $G$ ") before TMACS retrieves that data.

\begin{tabular}{|c|c|c|c|}
\hline Step & Perform & Expected Result & Initial \\
\hline 1 & $\begin{array}{l}\text { Select a surface-level } \\
\text { sensor has been configured } \\
\text { for polling from SACS. }\end{array}$ & $\begin{array}{l}\text { Record the sensor and tank names. } \\
\text { Sensor } \\
\text { Tank }\end{array}$ & \\
\hline 2. & $\begin{array}{l}\text { On the Hanford Tank Farm } \\
\text { Facilities workspace, click } \\
\text { on the tank icon for the } \\
\text { selected tank. } \\
\text { Click on the surface-level } \\
\text { icon. }\end{array}$ & $\begin{array}{l}\text { Verify that the Sensor Trend workspace } \\
\text { appears. }\end{array}$ & \\
\hline 3. & $\begin{array}{l}\text { Click on the detail button. } \\
\text { (Upper right-hand corner } \\
\text { of the Sensor Trend } \\
\text { workspace.) }\end{array}$ & $\begin{array}{l}\text { Verify that the details about the surface-level } \\
\text { sensor appear. } \\
\text { Record the: } \\
\text { Current Reading } \\
\text { Last Good Reading } \\
\text { Sensor Type Name } \\
\text { slvl_dttm }\end{array}$ & \\
\hline 4. & Close the Sensor Trend & & \\
\hline
\end{tabular}


HNF-3967, Rev. 3

\begin{tabular}{|l|l|l|l|}
\hline Step & \multicolumn{1}{|c|}{ Perform } & \multicolumn{1}{|c|}{ Expected Result } & Initial \\
\hline 5. & $\begin{array}{l}\text { Obtain the last SACS } \\
\text { database reading for the } \\
\text { selected tank. Note: This } \\
\text { will be on the UDO server } \\
\text { most likely.) This may be } \\
\text { obtained from the system } \\
\text { administrator using the } \\
\text { following code: }\end{array}$ & $\begin{array}{l}\text { Verify that the values obtained in this step } \\
\text { match the values recorded in Step 3. } \\
\text { lp_LastSLVLReading } \\
\text { 'Tank Name]' } \\
\text { select* } \\
\text { from } \\
\text { TMACS_LASTSLVLREA } \\
\text { DING }\end{array}$ & \\
\hline
\end{tabular}

\subsection{POINT PROCESSING}

\subsubsection{Continuous Sensor (Non Rate of Change) Automated Functional Test}

This procedure automatically tests the state changes for a continuous sensor.

\begin{tabular}{|c|c|c|c|}
\hline Step & Perform & Expected Result & Initial \\
\hline 1. & $\begin{array}{l}\text { On the POINT } \\
\text { PROCESSING } \\
\text { FUNCTIONAL TEST } \\
\text { workspace click on the } \\
\text { Point Processing for } \\
\text { Continuous Point - All } \\
\text { Function excepts Rate of } \\
\text { Change button }\end{array}$ & $\begin{array}{l}\text { Verify the CONTINUOUS FUNCTIONAL } \\
\text { TEST (Except ROC) workspace appears. }\end{array}$ & \\
\hline 2. & $\begin{array}{l}\text { On the CONTINUOUS } \\
\text { FUNCTIONAL TEST } \\
\text { (Except ROC) workspace: } \\
\text { - Set the Step Mode to } \\
\text { "Off." } \\
\text { - Set Print Results to } \\
\text { "Last" } \\
\text { Activate the "Run Point } \\
\text { Processing" button. }\end{array}$ & Verify that the process continues to completion & \\
\hline 3. & Examine the results & Verify no errors are reported. & \\
\hline 4. & Print the final workspace. & Keep printout for project files. & \\
\hline
\end{tabular}




\subsubsection{Continuous Sensor (Rate of Change) Automated Functional Test}

\begin{tabular}{|l|l|l|l|}
\hline Step & \multicolumn{1}{|c|}{ Perform } & \multicolumn{1}{c|}{ Expected Result } & Initial \\
\hline 1. & $\begin{array}{l}\text { On the POINT } \\
\text { PROCESSING } \\
\text { FUNCTIONAL TEST } \\
\text { workspace click on the } \\
\text { Point Processing for } \\
\text { Continuous Point -Rate } \\
\text { of Change button. }\end{array}$ & $\begin{array}{l}\text { Verify the CONTINUOUS FUNCTIONAL } \\
\text { TEST (With ROC) workspace appears. }\end{array}$ & \\
\hline 2. & $\begin{array}{l}\text { On the ROC } \\
\text { FUNCTIONAL TEST } \\
\text { workspace: } \\
\text { Set the Step Mode to } \\
\text { "Off." } \\
\text { Set Print Results to "Last" } \\
\text { Activate the "Run Point } \\
\text { Processing" button. }\end{array}$ & Verify that the process continues to completion. & \\
\hline 3. & Examine the workspace. & Verify no errors are reported. & \\
\hline 4. & Print the final workspace. & Keep printout for project files. & \\
\hline
\end{tabular}

\subsubsection{Discrete Sensor Automated Functional Test}

This procedure automatically tests the state changes of a discrete sensor.

\begin{tabular}{|l|l|l|l|}
\hline Step & \multicolumn{1}{|c|}{ Perform } & \multicolumn{1}{c|}{ Expected Result } & Initial \\
\hline 1. & $\begin{array}{l}\text { On the POINT } \\
\text { PROCESSING } \\
\text { FUNCTIONAL TEST } \\
\text { workspace click on the } \\
\text { Point Processing for } \\
\text { Discrete Points - All } \\
\text { Functions button }\end{array}$ & $\begin{array}{l}\text { Verify the DISCRETE FUNCTIONAL TEST } \\
\text { workspace appears. }\end{array}$ & \\
\hline 2. & $\begin{array}{l}\text { On the Discrete Functional } \\
\text { Test workspace: } \\
\text { Set the Step Mode to } \\
\text { "Off." } \\
\text { Set Print Results to "Last" } \\
\text { Activate the "Run Point } \\
\text { Processing " button. }\end{array}$ & Verify that the process continues to completion. & \\
\hline 3. & Examine the workspace. & Verify no errors are reported. & \\
\hline 4. & Print the final workspace. & Keep printout for project files. & \\
\hline
\end{tabular}

\subsubsection{Operation of MOST RECENT ALARM and CURRENT ALARMS}


HNF-3967, Rev. 3

Prior to running this test the administrator should do the following:

1. Acknowledge all alarms so Current Alarm count goes to zero. Note: if this is not done, then note the number of current alarms.

2. Verify the following workspaces are visible:

- DISCRETE FUNCTIONAL TEST

- MOST RECENT ALARM

- CONTROL-PANEL

- CURRENT ALARM

\begin{tabular}{|c|c|c|c|}
\hline Step & Perform & Expected Result & Initial \\
\hline 1. & $\begin{array}{l}\text { On the Discrete Functional } \\
\text { Test Workspace } \\
\text { Set the Step Mode in ON. } \\
\text { Activate the RUN POINT } \\
\text { PROCESSING button. } \\
\text { Examine the Current } \\
\text { Alarm box. }\end{array}$ & Note the number of current alarms & \\
\hline 2. & $\begin{array}{l}\text { Enter } 4 \text { in Dip-switch type- } \\
\text { in box on the Discrete } \\
\text { Functional Test } \\
\text { Workspace. }\end{array}$ & $\begin{array}{l}\text { Verify the following: } \\
\text { - A white message for the discrete alarm is } \\
\text { generated in the MOST RECENT ALARM } \\
\text { workspace. } \\
\text { - Sensor Icon Blinking = false } \\
\text { - Tank Icon Blinking = false } \\
\text { - No Current Alarms = } 1 \text { more than Step } 1 \text { on } \\
\text { the following workspaces: } \\
\text { 1. CURRENT ALARMS } \\
\text { 2. CONTROL PANEL } \\
\text { 3. MOST RECENT ALARM }\end{array}$ & \\
\hline 3. & $\begin{array}{l}\text { Enter }-1 \text { in Dip-switch } \\
\text { type-in box on the } \\
\text { Discrete Functional Test } \\
\text { Workspace. }\end{array}$ & $\begin{array}{l}\text { Verify the following: } \\
\text { - Sensor Icon Blinking }=\text { false } \\
\text { - Tank Icon Blinking = false } \\
\text { - No Current Alarms }=1 \text { more than Step } 1 \text { on } \\
\text { the following workspaces: } \\
\text { 1. CURRENT ALARMS } \\
\text { 2. CONTROL PANEL } \\
\text { 3. MOST RECENT ALARM }\end{array}$ & \\
\hline 4. & $\begin{array}{l}\text { Enter } 2 \text { in Dip-switch type- } \\
\text { in box on the Discrete } \\
\text { Functional Test } \\
\text { Workspace. }\end{array}$ & $\begin{array}{l}\text { Verify the following: } \\
\text { - A discrete alarm message is generated in } \\
\text { the MOST RECENT ALARM workspace. } \\
\text { - Sensor Icon Blinking = true } \\
\text { - Tank Icon Blinking = true } \\
\text { - No. Current Alarms }=2 \text { more than in Step } 1\end{array}$ & \\
\hline
\end{tabular}


HNF-3967, Rev. 3

\begin{tabular}{|c|c|c|c|}
\hline Step & Perform & Expected Result & Initial \\
\hline & & $\begin{array}{l}\text { on the following workspaces: } \\
\text { 1. CURRENT ALARMS } \\
\text { 2. CONTROL PANEL } \\
\text { 3. MOST RECENT ALARM }\end{array}$ & \\
\hline 5. & $\begin{array}{l}\text { On the Most Recent Alarm } \\
\text { workspace activate the } \\
\text { GOTO button }\end{array}$ & $\begin{array}{l}\text { Verify the following: } \\
\text { - TANK TEST-201 STATUS workspace is } \\
\text { brought to the top of the screen. } \\
\text { - The sensor is in alarm. }\end{array}$ & \\
\hline 6. & $\begin{array}{l}\text { Enter } 0 \text { in Dip-switch type- } \\
\text { in box on the Discrete } \\
\text { Functional Test } \\
\text { Workspace. }\end{array}$ & $\begin{array}{l}\text { Verify the following: } \\
\text { - Discrete alarm message is reset. } \\
\text { - No. Current Alarms }=2 \text { more than Step } 1 \\
\text { on the following workspaces: } \\
\text { 1. CURRENT ALARMS } \\
\text { 2. CONTROL PANEL } \\
\text { 3. MOST RECENT ALARM }\end{array}$ & \\
\hline 7. & $\begin{array}{l}\text { Acknowledge alarm } \\
\text { message in MOST } \\
\text { RECENT ALARM } \\
\text { Window by clicking on it. }\end{array}$ & $\begin{array}{l}\text { Verify the following: } \\
\text { - Alarm Message disappears. } \\
\text { - Sensor Icon Blinking = false } \\
\text { - Tank Icon Blinking = false } \\
\text { - No. Current Alarms = } 1 \text { more than Step } 1 \\
\text { on the following workspaces: } \\
\text { 1. CURRENT ALARMS } \\
\text { 2. CONTROL PANEL } \\
\text { 3. MOST RECENT ALARM }\end{array}$ & \\
\hline 8. & $\begin{array}{l}\text { Acknowledge the White } \\
\text { alarm message }\end{array}$ & $\begin{array}{l}\text { Verify the following: } \\
\text { - Alarm Message disappears } \\
\text { - Sensor Icon Blinking = false } \\
\text { - Tank Icon Blinking = false } \\
\text { - No. Current Alarms = the same as in Step I } \\
\text { on the following workspaces: } \\
\text { 1. CURRENT ALARMS } \\
\text { 2. CONTROL PANEL } \\
\text { 3. MOST RECENT ALARM }\end{array}$ & \\
\hline
\end{tabular}

\subsubsection{Operation of Sensor Delta Band and Alarm Deadband}

This test will verify that the operation of the sensor band and the alarm deadband for continuous sensors.

Prior to running this test the administrator should do the following:

1. Verify that the Rate of Change processing is disabled for Sensor Continuous-200001. 
HNF-3967, Rev. 3

2. Verify that the parameters for Sensor Continuous-200001 are set to match the parameters in Table 1. (See Prerequisites)

3. Verify that the following workspaces are visible.

- CONTINUOUS FUNCTIONAL TEST

- MOST RECENT ALARM

\begin{tabular}{|c|c|c|c|}
\hline Step & Action & Verify the Alarm Condition is: & Initial \\
\hline 1. & $\begin{array}{l}\text { On the Continuous Functional Test } \\
\text { Workspace } \\
\text { - Set the Step Mode in ON. } \\
\text { - Activate the RUN POINT } \\
\text { PROCESSING button. } \\
\text { - Enter } 14.8 \text { in milli-amps type-in } \\
\text { box }\end{array}$ & NORMAL & \\
\hline 2. & Enter 14.4 in milli-amps type-in box & NORMAL & \\
\hline 3. & Enter 14.3 in milli-amps type-in box & NORMAL & \\
\hline 4. & Enter 14.8 in milli-amps type-in box & NORMAL & \\
\hline 5. & Enter 15.2 in milli-amps type-in box & ALARM-HIGH & \\
\hline 6. & Enter 15.3 in milli-amps type-in box & ALARM-HIGH & \\
\hline 7. & Enter 14.9 in milli-amps type-in box & ALARM-HIGH & \\
\hline 8. & Enter 14.6 in milli-amps type-in box & ALARM-HIGH & \\
\hline 9. & Enter 14.0 in milli-amps type-in box & NORMAL & \\
\hline 10. & Enter 13.5 in milli-amps type-in box & NORMAL & \\
\hline 11. & Enter 15.0 in milli-amps type-in box & ALARM-HIGH & \\
\hline 12. & Enter 10.6 in milli-amps type-in box & NORMAL & \\
\hline 13. & Enter 15.0 in milli-amps type-in box & ALARM-HIGH & \\
\hline 14. & Enter 9.9 in milli-amps type-in box & ALARM-LOW & \\
\hline 15. & Enter $\mathbf{1 0 . 2}$ in milli-amps type-in box & ALARM-LOW & \\
\hline 16. & Enter $\mathbf{1 0 . 5}$ in milli-amps type-in box & ALARM-LOW & \\
\hline 17. & Enter 11.0 in milli-amps type-in box & NORMAL & \\
\hline 18. & Enter $\mathbf{1 1 . 5}$ in milli-amps type-in box & NOF & \\
\hline
\end{tabular}

\subsubsection{Operation of Enable/Disable Procedures}

Verify that the following workspaces are visible.

- Continuous Function Test

- Tank Test-201

- Enable/Disable Point Processing

- Most Recent Alarm

- Discrete-200001 Sensor 


\begin{tabular}{|c|c|c|c|}
\hline Step & Perform & Expected Result & Initial \\
\hline 1 . & $\begin{array}{l}\text { On the Continuous } \\
\text { Functional Test } \\
\text { workspace enter } 17 \text { in the } \\
\text { "milliamps" type-in box. }\end{array}$ & $\begin{array}{l}\text { Verify the following: } \\
\text { - Alarm message is displayed } \\
\text { - Number of Current Alarms increases by } \\
\text { one. }\end{array}$ & \\
\hline 2. & $\begin{array}{l}\text { Position the enable/disable } \\
\text { pointer over the } \\
\text { Continuous-200001 sensor } \\
\text { and activate the button } \\
\text { "Toggle Point". }\end{array}$ & $\begin{array}{l}\text { Verify that the following conditions occur: } \\
\text { - Blue message is displayed: "The POINT- } \\
\text { PROCESSING of CONTNUOUS-200001 } \\
\text { has been DISABLED", with the timestamp } \\
\text { of this change. } \\
\text { - Previous alarm message disappears and the } \\
\text { total "Number of Current Alarms" remains } \\
\text { the same. } \\
\text { - Point processing attribute of sensor changes } \\
\text { to false. } \\
\text { - Sensor turns gray. } \\
\text { Tank color is the same as the DISCRETE- } \\
200001 \text { sensor color. }\end{array}$ & \\
\hline 3. & $\begin{array}{l}\text { With the enable/disable } \\
\text { pointer still over the } \\
\text { Continuous-200001 sensor, } \\
\text { activate the button "Toggle } \\
\text { Point". }\end{array}$ & $\begin{array}{l}\text { Verify that the following conditions occur: } \\
\text { Blue message is displayed: "The POINT- } \\
\text { PROCESSING of CONTINUOUS-200001 } \\
\text { has been ENABLED", with the timestamp } \\
\text { of this change. } \\
\text { - "Number of Current Alarms" remains the } \\
\text { same. } \\
\text { - Point processing attribute of sensor changes } \\
\text { to true. } \\
\text { - Sensor turns white. } \\
\text { - Tank color will be based on the alarm } \\
\text { precedence of the sensors associated with } \\
\text { the tank. }\end{array}$ & \\
\hline 4. & $\begin{array}{l}\text { Select a tank on the HTFF } \\
\text { workspace that has a good } \\
\text { mix of sensor types. } \\
\text { Enter the chosen tank in } \\
\text { the type-in box labeled } \\
\text { "Tank on which to enable / } \\
\text { disable point processing". } \\
\text { Without moving the } \\
\text { enable/disable pointer } \\
\text { activate the button "Toggle } \\
\text { Point". }\end{array}$ & $\begin{array}{l}\text { Verify that the following conditions occur: } \\
\text { - Blue message is displayed: "The POINT- } \\
\text { PROCESSING of [the nearest sensor to the } \\
\text { pointer-frequently the level sensor] has } \\
\text { been DISABLED", with the timestamp of } \\
\text { this change; } \\
\text { - Point processing attribute of sensor changes } \\
\text { to false; } \\
\text { - Sensor turns gray; } \\
\text { - Tank color is the same as the highest } \\
\text { priority sensor alarm }\end{array}$ & \\
\hline
\end{tabular}


HNF-3967, Rev. 3

\begin{tabular}{|c|c|c|c|}
\hline Step & Perform & Expected Result & Initial \\
\hline 5 & $\begin{array}{l}\text { Activate the button } \\
\text { "Toggle Point" again. }\end{array}$ & $\begin{array}{l}\text { Verify that the following conditions occur: } \\
\text { - Blue message is displayed: "The POINT- } \\
\text { PROCESSING of [the nearest sensor to the } \\
\text { pointer] has been ENABLED", with the } \\
\text { timestamp of this change; } \\
\text { - Point processing attribute of sensor changes } \\
\text { to true; } \\
\text { - Sensor turns white; } \\
\text { - Tank icon turns white or the color of the } \\
\text { highest priority sensor alarm. }\end{array}$ & - \\
\hline 6. & $\begin{array}{l}\text { Activate the button" All } \\
\text { points in tank off". }\end{array}$ & $\begin{array}{l}\text { Verify that the following conditions occur: } \\
\text { Blue messages are displayed: "The POINT- } \\
\text { PROCESSING of [each sensor monitoring } \\
\text { this tank] has been DISABLED" with the } \\
\text { time of this change; } \\
\text { - Point processing attribute of sensors } \\
\text { changes to false; } \\
\text { - Sensors turn gray; } \\
\text { - All sensor alarms associated with this tank } \\
\text { are cleared; } \\
\text { - Tank color turns gray. }\end{array}$ & \\
\hline 7. & $\begin{array}{l}\text { Activate the button "Al! } \\
\text { points in tank on". }\end{array}$ & $\begin{array}{l}\text { Verify that the following conditions occur: } \\
\text { Blue messages are displayed: "The POINT- } \\
\text { PROCESSING of [each sensor monitoring } \\
\text { this tank] has been ENABLED" with the } \\
\text { time of this change; } \\
\text { - Point processing attribute of sensors } \\
\text { changes to true; } \\
\text { - Sensors turn white; } \\
\text { - Tank turns white. }\end{array}$ & \\
\hline 8. & $\begin{array}{l}\text { On the Current Alarms } \\
\text { workspace click on the } \\
\text { Clear All Blue Messages } \\
\text { button. }\end{array}$ & $\begin{array}{l}\text { Verify the Blue Messages disappear from the } \\
\text { Current Alarms list. }\end{array}$ & \\
\hline 9. & $\begin{array}{l}\text { Hide the following } \\
\text { workspaces: } \\
\text { - Tank (selected in test) } \\
\text { - Enable/Disable Point } \\
\text { Processing } \\
\text { - Discrete-200001 } \\
\text { Sensor } \\
\end{array}$ & Verify the workspaces are hidden. & \\
\hline
\end{tabular}




\subsubsection{Miscellaneous Alarm Tests}

The purpose of this test is to verify the relationships between the sensor icons, tank icon, Current Alarms Workspace and the annuciator.

Prior to running this test the administrator should do the following:

1. Make sure the following workspaces visible.

- Functional Test Selection Workspace (Only to see the TANK-ICON-TEST-201 icon)

- Continuous Functional Test Workspace. Also perform following:

1. Set Step Mode On

2. Activate the Run Point Processing button

- Discrete Functional Test Workspace. Also perform following:

1. Set Step Mode On

2. Activate the Run Point Processing button

- TANK TEST-201 workspace.

- MOST RECENT ALARM workspace

- Discrete-200001 Sensor

2. Make sure the enunciator is enabled. This is done by the following:

- $\quad$ Bring up the TMACS-LIB workspace and its subworkspace labeled

STARTUP-WS and Activate the "TOGGLE-AUDIBLE" button and verify that the display of the alarm-audible symbol changes from false to true.

\begin{tabular}{|c|c|c|c|}
\hline Step & Perform & Expected Resuit & Initial \\
\hline 1. & $\begin{array}{l}\text { Enter } 1 \text { in Dip-switch type-in box } \\
\text { on the Discrete Functional Test } \\
\text { Workspace. } \\
\text { Enter a } 11 \text { in Milli-amp type-in } \\
\text { box on the Continuous } \\
\text { Functional Test Workspace } \\
\text { Note: May have to click on the } \\
\text { Run Point Process button on both } \\
\text { the Discrete and Continuous } \\
\text { Function Test Workspaces. }\end{array}$ & $\begin{array}{l}\text { Beep } \\
\text { Beep }=\text { true } \\
\text { Most Recent Alarm } \\
\text { - Message Status = Closing } \\
\text { - } \quad \text { Display Color = Yellow } \\
\text { - Text Color = Red } \\
\\
\text { Discrete Functional Test Workspace } \\
\text { Discrete - 2001 } \\
\text { - Discrete Icon Blinking = true } \\
\text { - Display Color }=\text { YELLOW } \\
\text { Blink-off Color = GRAY } \\
\text { Alarm Aux Color = YELLOW }\end{array}$ & \\
\hline
\end{tabular}


HNF-3967, Rev. 3

\begin{tabular}{|c|c|c|c|}
\hline Step & Perform & Expected Result & Initial \\
\hline & $\cdot$ & $\begin{array}{l}\text { Tank Icon Test-201 } \\
\text { - } \quad \text { Icon Blinking = true } \\
\text { - } \quad \text { Display Color = YELLOW } \\
\text { Latink-off Color = GRAY } \\
\text { - } \quad \text { Display Color = Yellow } \\
\text { Continuous Functional Test Workspace } \\
\text { Continuous -2001 } \\
\text { - } \text { Cont. Icon Blinking = false } \\
\text { - } \quad \text { Display Color = GREEN } \\
\text { - } \text { Blink-off Color = (N/A - skip) } \\
\text { - } \quad \text { Alarm Aux Color = TRANSPARENT } \\
\text { Tank Icon Test-201 } \\
\text { - Icon Blinking = true } \\
\text { - Display Color = YELLOW } \\
\text { Blink-off Color = GRAY } \\
\text { Latest Alarm Message } \\
\text { - } \quad \text { Display Color = Yellow }\end{array}$ & \\
\hline 2. & $\begin{array}{l}\text { Activate ACK ALARMS Button } \\
\text { on Tank Test } 201 \text { status }\end{array}$ & 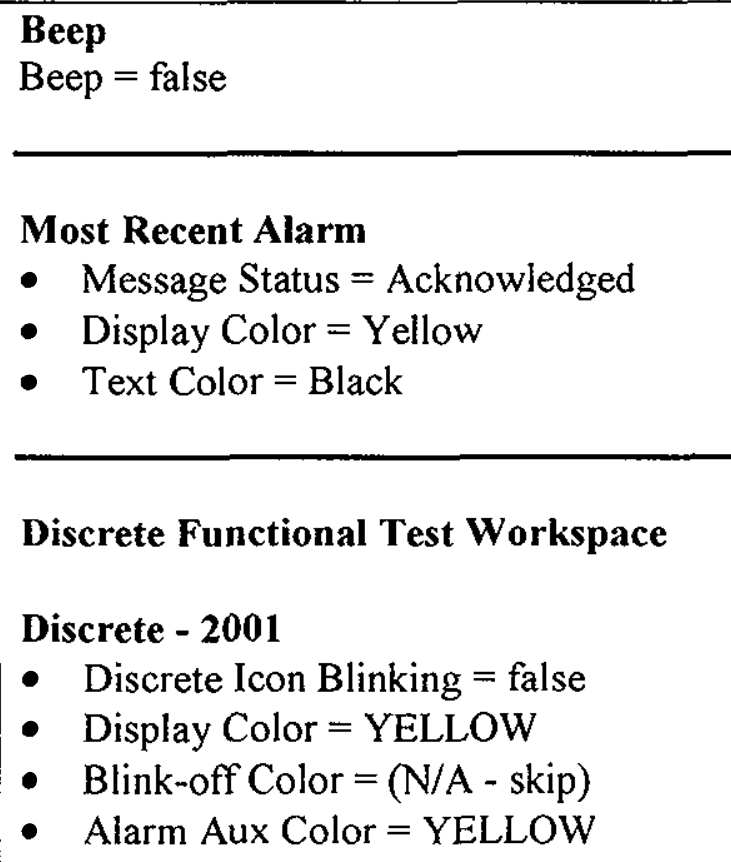 & \\
\hline
\end{tabular}


HNF-3967, Rev. 3

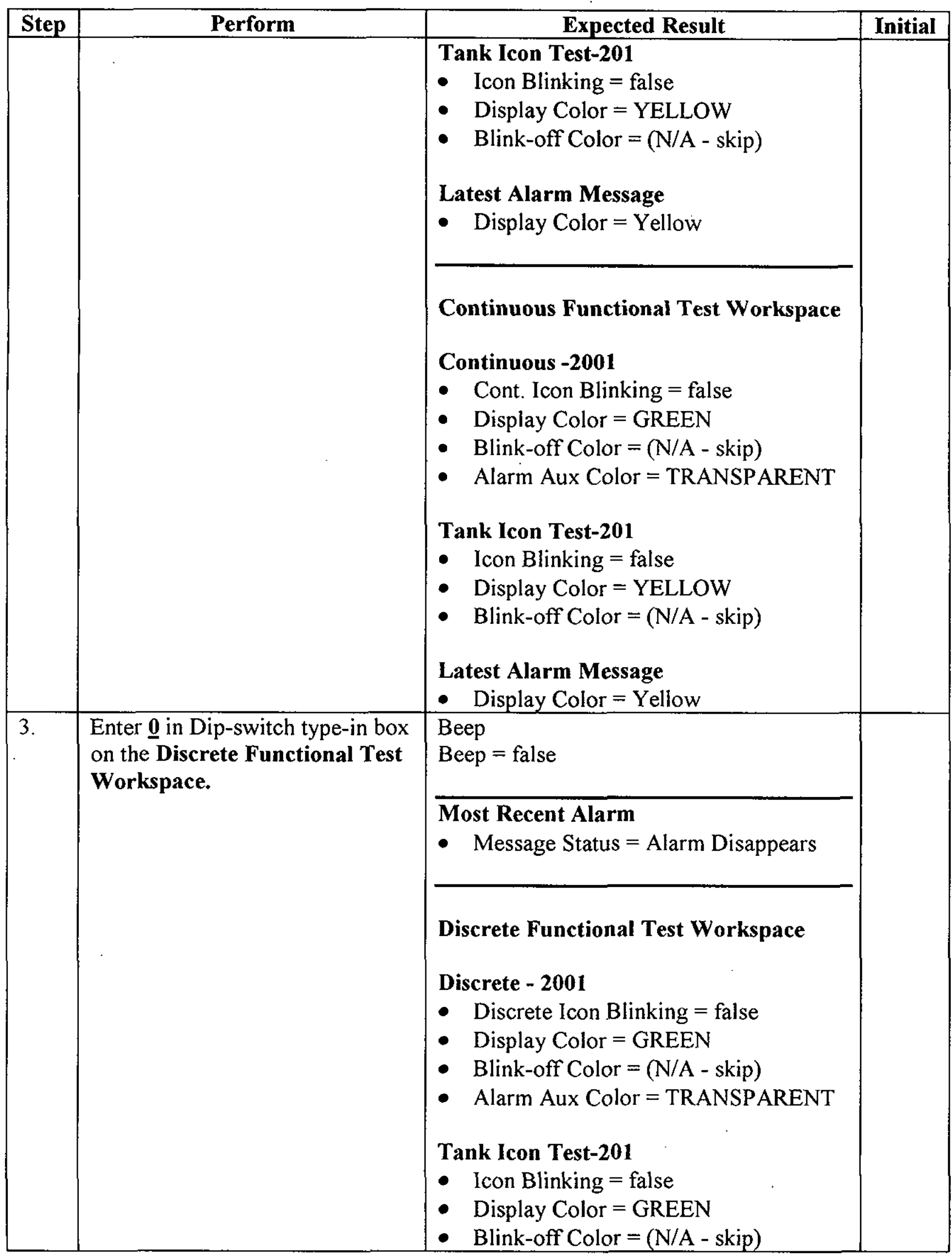


HNF-3967, Rev. 3

\begin{tabular}{|c|c|c|c|}
\hline Step & Perform & Expected Result & Initial \\
\hline & - & $\begin{array}{l}\text { Latest Alarm Message } \\
\text { - Display Color = YELLOW } \\
\text { Continuous Functional Test Workspace } \\
\text { Continuous -2001 } \\
\text { - Cont. Icon Blinking = false } \\
\text { - } \quad \text { Display Color = GREEN } \\
\text { - } \text { Blink-off Color = (N/A - skip) } \\
\text { - } \quad \text { Alarm Aux Color = TRANSPARENT } \\
\text { Tank Icon Test-201 } \\
\text { - Icon Blinking = false } \\
\text { - Display Color = GREEN } \\
\text { - } \quad \text { Blink-off Color = (N/A - skip) } \\
\text { Latest Alarm Message } \\
\text { - Display Color = YELLOW }\end{array}$ & . \\
\hline 4. & $\begin{array}{l}\text { Enter a } \underline{17} \text { in Milli-amp type-in } \\
\text { box on the Continuous } \\
\text { Functional Test Workspace }\end{array}$ & $\begin{array}{l}\text { Beep } \\
\text { Beep }=\text { true } \\
\text { Most Recent Alarm } \\
\text { - } \quad \text { Message Status = ALARM HIGH } \\
\text { - } \quad \text { Display Color = RED } \\
\text { Text Color = YELLOW } \\
\text { Discrete Functional Test Workspace } \\
\text { Discrete - 2001 } \\
\text { - Discrete Icon Blinking = false } \\
\text { - Display Color = GREEN } \\
\text { - Blink-off Color = (N/A - skip) } \\
\text { - Alarm Aux Color }=\text { TRANSPARENT } \\
\text { Tank Icon Test-201 } \\
\text { - Icon Blinking = true } \\
\text { - Display Color = RED } \\
\text { Blink-off Color = GRAY } \\
\text { Latest Alarm Message }\end{array}$ & \\
\hline
\end{tabular}


HNF-3967, Rev. 3

\begin{tabular}{|c|c|c|c|}
\hline Step & Perform & Expected Result & Initial \\
\hline & . & $\begin{array}{l}\text { - } \text { Display Color = YELLOW } \\
\text { Continuous Functional Test Workspace } \\
\text { Continuous -2001 } \\
\text { - } \text { Cont. Icon Blinking = true } \\
\text { - } \text { Display Color = RED } \\
\text { - } \quad \text { Blink-off Color = GRAY } \\
\text { Tank Aux Color = RED } \\
\text { Tank Icon Test-201 } \\
\text { - } \quad \text { Display Color = RED } \\
\text { - } \quad \text { Blink-off Color = GRAY } \\
\text { Latest Alarm Message } \\
\text { - Display Color = RED }\end{array}$ & \\
\hline 5. & $\begin{array}{l}\text { Enter } 1 \text { in Dip-switch type-in box } \\
\text { on the Discrete Functional Test } \\
\text { Workspace. }\end{array}$ & $\begin{array}{l}\text { Beep } \\
\text { Beep = true } \\
\text { Most Recent Alarm } \\
\text { - Message Status = CLOSING } \\
\text { - } \quad \text { isplay Color = YELLOW } \\
\text { - Text Color = RED } \\
\text { Discrete Functional Test Workspace } \\
\text { Discrete - 2001 } \\
\text { - Discrete Icon Blinking = true } \\
\text { - Display Color = YELLOW } \\
\text { - Blink-off Color = GRAY } \\
\text { - Alarm Aux Color = YELLOW } \\
\text { Tank Icon Test-201 } \\
\text { - Icon Blinking = true } \\
\text { - Display Color = RED } \\
\text { - Blink-off Color = GRAY } \\
\text { Latest Alarm Message }\end{array}$ & \\
\hline
\end{tabular}


HNF-3967, Rev. 3

\begin{tabular}{|c|c|c|c|}
\hline Step & Perform & Expected Result & Initial \\
\hline & & $\begin{array}{l}\text { - } \text { Display Color = YELLOW } \\
\text { Continuous Functional Test Workspace } \\
\text { Continuous -2001 } \\
\text { - Cont. Icon Blinking = true } \\
\text { - } \quad \text { Display Color = RED } \\
\text { - Blink-off Color = GRAY } \\
\text { - } \quad \text { Alarm Aux Color = RED } \\
\text { Tank Icon Test-201 } \\
\text { - Icon Blinking = true } \\
\text { - Display Color = RED } \\
\text { - Blink-off Color = GRAY } \\
\text { Latest Alarm Message } \\
\text { - Display Color = RED }\end{array}$ & \\
\hline 6. & $\begin{array}{l}\text { Enter a } 25 \text { in Milli-amp type-in } \\
\text { box on the Continuous } \\
\text { Functional Test Workspace }\end{array}$ & $\begin{array}{l}\text { Beep } \\
\text { Beep = true } \\
\text { Most Recent Alarm } \\
\text { - } \quad \text { Message Status = Reading Out Of } \\
\text { Range } \\
\text { - } \quad \text { Display Color = WHITE } \\
\text { - Text Color = BLACK } \\
\text { Discrete Functional Test Workspace } \\
\text { Discrete - 2001 } \\
\text { - Discrete Icon Blinking = true } \\
\text { Display Color }=\text { YELLOW } \\
\text { Blink-off Color = GRAY } \\
\text { Alarm Aux Color }=\text { YELLOW } \\
\text { Tank Icon Test-201 } \\
\text { - Icon Blinking = true } \\
\text { - Display Color = YELLOW } \\
\text { Latest Alarm Message }\end{array}$ & \\
\hline
\end{tabular}


HNF-3967, Rev. 3

\begin{tabular}{|c|c|c|c|}
\hline Step & Perform & Expected Result & Initial \\
\hline. & . & $\begin{array}{l}\text { - } \text { Display Color = YELLOW } \\
\text { Continuous Functional Test Workspace } \\
\text { Continuous }-\mathbf{2 0 0 1} \\
\text { - Cont. Icon Blinking = true } \\
\text { - } \quad \text { Display Color = WHITE } \\
\text { - Blink-off Color = RED } \\
\text { - } \text { Alarm Aux Color = RED } \\
\text { Tank Icon Test-201 } \\
\text { - Icon Blinking = true } \\
\text { - Display Color = YELLOW } \\
\text { - Blink-off Color = WHITE } \\
\text { Latest Alarm Message } \\
\text { - Display Color = WHITE }\end{array}$ & \\
\hline 7. & $\begin{array}{l}\text { Enter } \underline{3} \text { in Dip-switch type-in box } \\
\text { on the Discrete Functional Test } \\
\text { Workspace. }\end{array}$ & $\begin{array}{l}\text { Beep } \\
\text { Beep = true } \\
\text { MOST RECENT ALARM } \\
\text { - Message Status = Reading Out Of } \\
\text { Range } \\
\text { - Display Color = WHITE } \\
\text { Text Color = BLACK } \\
\text { CURRENT ALARM SCREEN } \\
\text { Message Status = Discrete 200001 } \\
\text { Resets } \\
\text { Display Color = GREEN } \\
\text { Text Color = BLACK } \\
\text { Discrete Functional Test Workspace } \\
\text { Discrete - 2001 } \\
\text { Discrete Icon Blinking = true } \\
\text { Display Color = GREEN }\end{array}$ & \\
\hline
\end{tabular}


HNF-3967, Rev. 3

\begin{tabular}{|c|c|c|c|}
\hline Step & Perform & Expected Result & Initial \\
\hline & 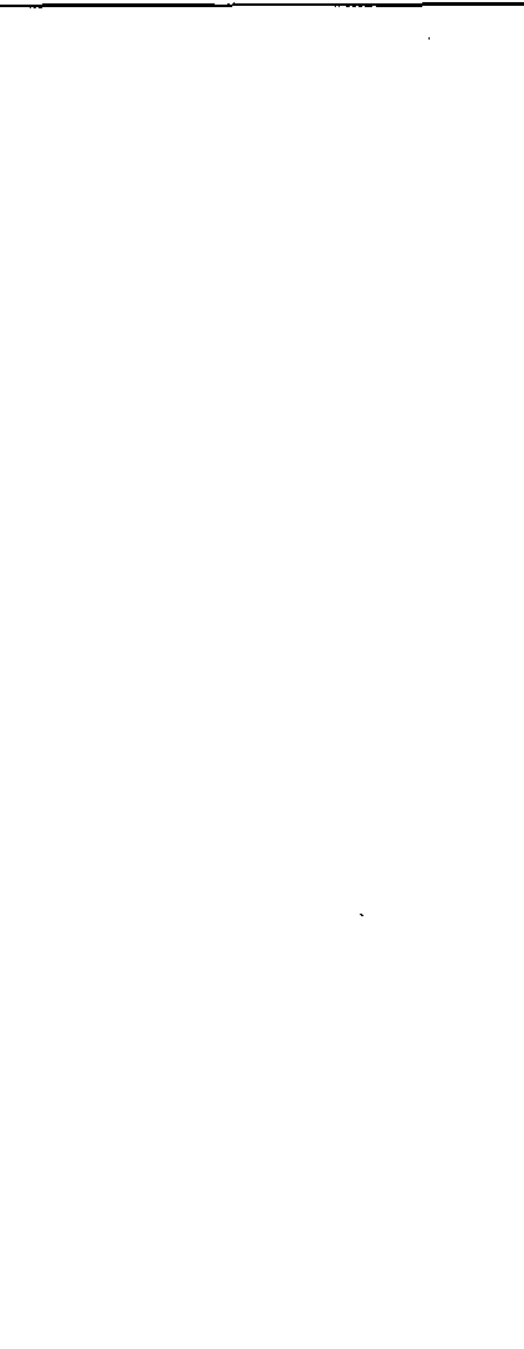 & 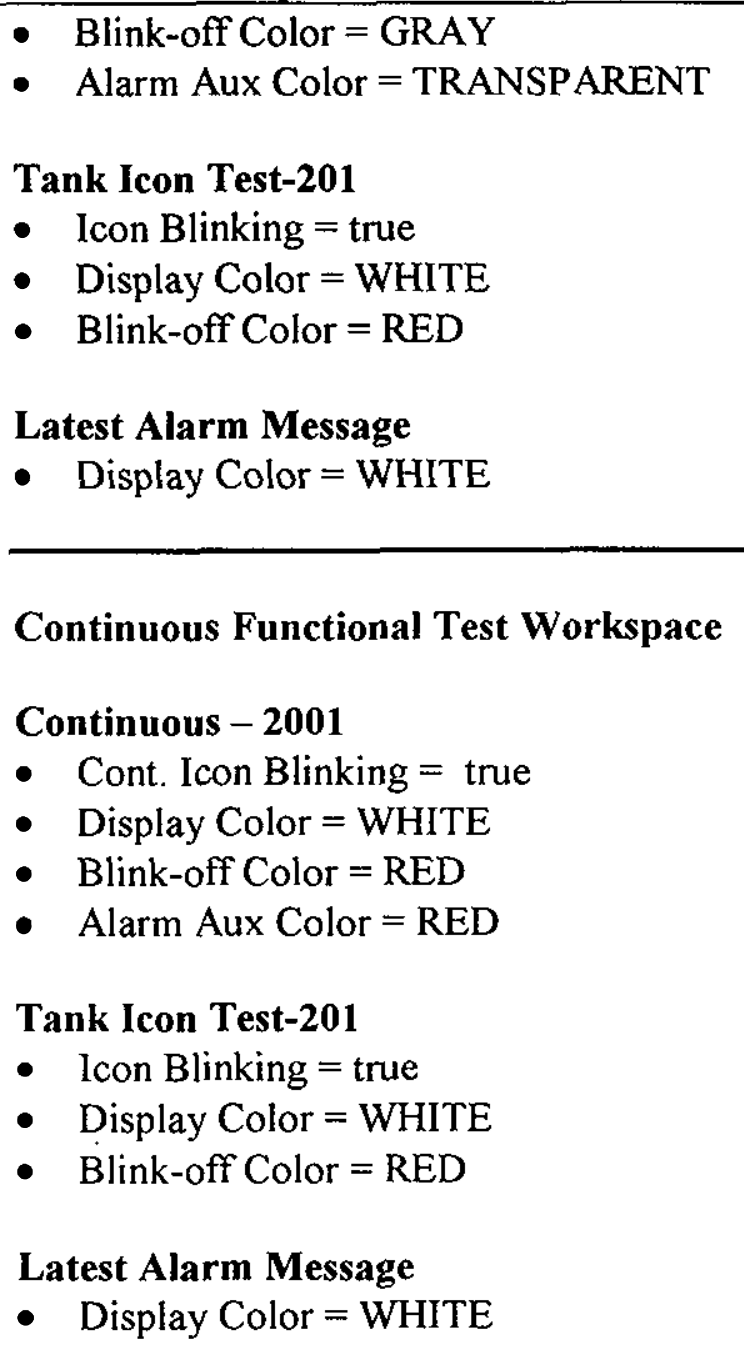 & \\
\hline 8. & $\begin{array}{l}\text { Acknowledge alarm messages } \\
\text { and hide the Point Processing } \\
\text { Functional Test workspaces. }\end{array}$ & $\begin{array}{l}\text { Verify the following: } \\
\text { beep is silenced } \\
\text { Point Processing Functional Test } \\
\text { workspaces are hidden. }\end{array}$ & \\
\hline
\end{tabular}

\subsection{LOGGING}

\subsubsection{Current}


The data files in this section are created upon system startup and then around midnight are closed and moved to the history directory and another file with the current date is created.

\subsubsection{Alarm Logging}

\begin{tabular}{|c|c|c|c|}
\hline Step & Perform & Expected Result & Initial \\
\hline 1. & $\begin{array}{l}\text { Examine the } \\
\text { almhst_YYYY_MM_DD_HHmm.dat. } \\
\text { Where } \\
\text { YYYY = the year } \\
\mathrm{MM}=\text { the month } \\
\mathrm{DD}=\text { the day } \\
\mathrm{HH}=\text { the hour } \\
\mathrm{mm}=\text { the minute } \\
\text { To examine the files it may be necessary } \\
\text { to stop G2 } 2^{\infty} \text {. The directory is located at } \\
\text { f: BackedUp } \backslash \text { TMACSDatalCurrent. }\end{array}$ & $\begin{array}{l}\text { Verify the following: } \\
\text { - High/low alarm conditions } \\
\text { and resets recorded } \\
\text { - Format match the } \\
\text { description given in the } \\
\text { LMSI External Letter, } \\
\text { RGG-SDI-99-001, TMACS } \\
\text { Data File Formats, Release } \\
\text { 11.0. }\end{array}$ & \\
\hline 2 & $\begin{array}{l}\text { Examine the } \\
\text { equip_fail_YYYY_MM_DD_HHmm.dat. } \\
\text { Where } \\
Y Y Y Y=\text { the year } \\
\mathrm{MM}=\text { the month } \\
\mathrm{DD}=\text { the day } \\
\mathrm{HH}=\text { the hour } \\
\mathrm{mm}=\text { the minute } \\
\text { To examine the files it may be necessary } \\
\text { to stop G2 } 2^{\infty} \text {. The directory is located at } \\
f^{\prime} \text { BackedUp } T \text { TMACSDatalCurrent. }\end{array}$ & $\begin{array}{l}\text { Verify the following } \\
\text { - Loss of communication } \\
\text { messages are recorded } \\
\text { - Format match the } \\
\text { description given in the } \\
\text { LMSI External Letter, } \\
\text { RGG-SDI-99-001, TMACS } \\
\text { Data File Formats, } \\
\text { Release 11.0. }\end{array}$ & \\
\hline
\end{tabular}




\subsubsection{Discrete Sensor Data Logging}

\begin{tabular}{|c|c|c|c|}
\hline Step & Perform & Expected Result & Initial \\
\hline$\overline{1 .}$ & 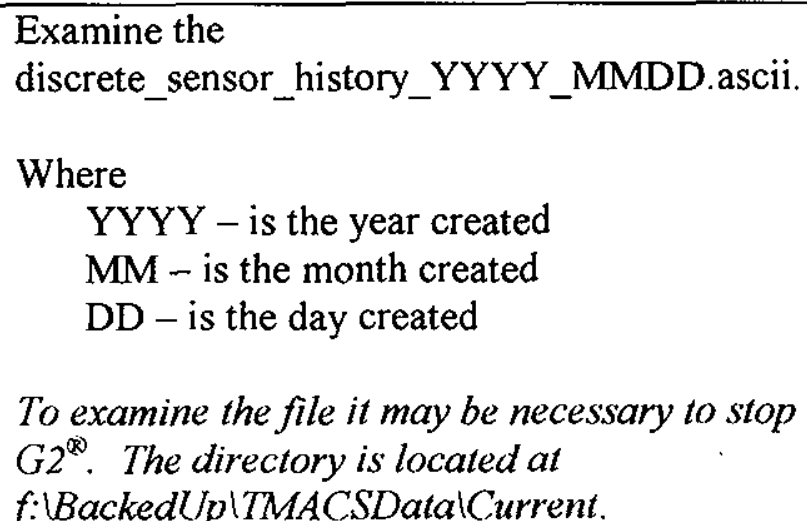 & $\begin{array}{l}\text { Verify the following: } \\
\text { Reading messages are } \\
\text { being recorded properly. } \\
\text { Format match the } \\
\text { description given in the } \\
\text { LMSI External Letter, } \\
\text { RGG-SDI-99-001, } \\
\text { TMACS Data File } \\
\text { Formats, Release 11.0. }\end{array}$ & \\
\hline
\end{tabular}

\subsubsection{Continuous Sensor Data Logging}

Continuous sensor history is recorded in the continuous_sensor_history_YYYY_MMDD.ascii file where

YYYY - is the year that the file was created.

$\mathrm{MM}$ - is the month that the file was created.

$\mathrm{DD}$ - is the day that the file was created.

To examine the file it may be necessary to stop $\mathrm{G} 2^{\infty)}$. The directory is:

- $f: \backslash B a c k e d U p \backslash T M A C S D a t a l C u r r e n t$.

\begin{tabular}{|c|c|c|c|}
\hline Step & Perform & Expected Result & Initial \\
\hline 1. & $\begin{array}{l}\text { Examine the continuous_sensor_history } \\
\text { YYYY_MMDD.ascii. } \\
\text { Where } \\
\text { YYYY - is the year created } \\
\text { MM - is the month created } \\
\text { DD - is the day created } \\
\text { To examine the file it may be necessary to stop } \\
G 2^{\infty} \text {. The directory is located at } \\
f: \text { Backedllp } \backslash \text { TMACSDatalCurrent. }\end{array}$ & $\begin{array}{l}\text { Verify the following: } \\
\text { - Reading messages are } \\
\text { being recorded properly. } \\
\text { - Format match the } \\
\text { description given in the } \\
\text { LMSI External Letter, } \\
\text { RGG-SDI-99-001, } \\
\text { TMACS Data File } \\
\text { Formats, Release 11.0. }\end{array}$ & \\
\hline
\end{tabular}

\subsubsection{Nightly File Creations}

Eight files are created nightly by TMACS (rdbms files are created around 4:00 AM, all others created around 12:00 AM) 
HNF-3967, Rev. 3

\begin{tabular}{|c|c|c|c|}
\hline Step & Perform & Verify & Initial \\
\hline 1. & $\begin{array}{l}\text { Let the system run over } \\
\text { night. (Note: Test } \\
\text { Director may opt to change } \\
\text { the system clock to } \\
\text { simulate overnight. This } \\
\text { requires time periods } \\
\text { around midnight and } \\
4 \text { AM) } \\
\text { Check the location } \\
\text { f:lBackedUplTMACSDatal } \\
\text { History to determine if the } \\
\text { files have been created. }\end{array}$ & $\begin{array}{l}\text { Verify that the following flat files are created: } \\
\text { - almhst_yyyy_mmdd_mmss.dat } \\
\text { - continuous_sensor_history yyyy_mmdd.ascii } \\
\text { - discrete_sensor_history_yyyy_mmdd.ascii } \\
\text { - equip_fail_yyyy_mmdd_mmss.dat } \\
\text { - perf_data_yyyy_mmdd.dat } \\
\text { - dst_data_yyyy_mmdd_mmss.rdbms } \\
\text { - sst_data_yyyy_mmdd_mmss.rdbms } \\
\text { where: } \\
\text { yyyy = the year } \\
\text { mm = the month } \\
\text { dd = the day } \\
\text { hh = the hour } \\
\text { mm = the minute } \\
\text { Verify that the fields in the files match the } \\
\text { description given in the LMSI External Letter, } \\
\text { RGG-SDI-99-001,TMACS Data File Formats, } \\
\text { Release } 11.0 \text {. }\end{array}$ & \\
\hline
\end{tabular}

\subsection{PERFORMACE}

\subsubsection{CPU Use Vs Number of Continuous Points/Sec Performance Test}

\begin{tabular}{|c|c|c|c|}
\hline Step & Perform & Expected Result & Initial \\
\hline 1. & $\begin{array}{l}\text { On the Point Processing } \\
\text { Performance Test workspace click } \\
\text { on the "CPU Use Versus Number } \\
\text { of Continuous Points/Sec" } \\
\text { button. }\end{array}$ & Verify the correct workspace is shown. & \\
\hline 2. & $\begin{array}{l}\text { Click on the "Start Performance } \\
\text { Test" button. } \\
\text { After the Test Running box turns } \\
\text { to FALSE examine the results. } \\
\text { (The test will take about } \\
20 \text { minutes to run) }\end{array}$ & $\begin{array}{l}\text { Verify the test runs and that the } \\
\% \mathrm{CPU} / \mathrm{pt} / \mathrm{sec} \text { values are less than } 0.94 \\
\text { for all values of points/second. }\end{array}$ & \\
\hline 3. & Click on the "Print" button. & $\begin{array}{l}\text { Verify that the workspace prints. } \\
\text { Attach the printout to this test procedure. }\end{array}$ & \\
\hline 4. & $\begin{array}{l}\text { Hide the Performance Test } \\
\text { workspace(s) }\end{array}$ & Verify the workspace(s) is hidden. & \\
\hline
\end{tabular}




\subsubsection{CPU Use Vs Number of Discrete Points/Sec Performance Test}

\begin{tabular}{|c|c|c|c|}
\hline Step & Perform & Expected Result & Initial \\
\hline 1. & $\begin{array}{l}\text { On the Point Processing } \\
\text { Performance Test workspace click } \\
\text { on the "CPU Use Versus Number } \\
\text { of Discrete Points/Sec" button. }\end{array}$ & $\begin{array}{l}\text { Verify the correct Performance Test } \\
\text { workspace is shown. }\end{array}$ & \\
\hline 2. & $\begin{array}{l}\text { Click on the "Start Performance } \\
\text { Test" button. } \\
\text { After the Test Running box turns } \\
\text { to FALSE examine the results. } \\
\text { (The test will take about } \\
20 \text { minutes to run) }\end{array}$ & $\begin{array}{l}\text { Verify that the test runs and that the } \\
\% \mathrm{CPU} / \mathrm{pt} / \mathrm{sec} \text { values are less than } 0.82 \\
\text { for all values of points/second. }\end{array}$ & \\
\hline 3. & Click on the "Print" button. & $\begin{array}{l}\text { Verify that the workspace prints. } \\
\text { Attach the printout to this test procedure. }\end{array}$ & \\
\hline 4. & $\begin{array}{l}\text { Hide the Performance Test } \\
\text { workspace(s) }\end{array}$ & Verify the workspace(s) is hidden. & \\
\hline
\end{tabular}

\subsubsection{CPU Use Vs Pt-Processing Function for Continuous Points Performance Test}

\begin{tabular}{|c|c|c|c|}
\hline Step & Perform & Expected Result & Initial \\
\hline 1. & $\begin{array}{l}\text { On the Point Processing } \\
\text { Performance Test workspace } \\
\text { click on the Click on the } \\
\text { "CPU Use Versus Point- } \\
\text { Processing Function for } \\
\text { Continuous Points" button. }\end{array}$ & $\begin{array}{l}\text { Verify the correct Performance Test } \\
\text { workspace is shown. }\end{array}$ & \\
\hline 2. & $\begin{array}{l}\text { Click on the "Start } \\
\text { Performance Test" button. } \\
\text { After the Test Running box } \\
\text { turns to FALSE examine the } \\
\text { results. (The test will take } \\
\text { about } 20 \text { minutes } \text { to run) }\end{array}$ & $\begin{array}{l}\text { Verify that the test runs and that for each } \\
\text { Point Processing Breakdown that the } \\
\text { following criteria are met. } \\
\text { Update Pt. the \%CPU per points } / \mathrm{sec}<0.23 \\
\text { Deita Check the \%CPU per points } / \mathrm{sec}<0.15 \\
\text { Alarm Check the \%CPU per points } / \mathrm{sec}<0.07 \\
\text { ROC Check the \%CPU per points } / \mathrm{sec}<0.12 \\
\text { Log to Disk the \%CPU per points } / \mathrm{sec}<0.57\end{array}$ & \\
\hline 3. & Click on the "Print" button. & $\begin{array}{l}\text { Verify that the workspace prints. } \\
\text { Attach the printout to this test procedure. }\end{array}$ & \\
\hline 4. & $\begin{array}{l}\text { Hide the Performance Test } \\
\text { workspace }\end{array}$ & Verify the workspace is hidden. & \\
\hline
\end{tabular}

\subsubsection{CPU Use Vs Point-Processing Function for Discrete Points Performance Test}




\begin{tabular}{|c|c|c|c|}
\hline Step & Perform & Expected Result & Initial \\
\hline 1. & $\begin{array}{l}\text { On the Point Processing } \\
\text { Performance Test } \\
\text { workspace click on the } \\
\text { Click on the "CPU Use } \\
\text { Versus Point-Processing } \\
\text { Function for Discrete } \\
\text { Points" button. }\end{array}$ & $\begin{array}{l}\text { Verify the correct Performance Test workspace is } \\
\text { shown. }\end{array}$ & \\
\hline 2. & $\begin{array}{l}\text { Click on the "Start } \\
\text { Performance Test" button. } \\
\text { After the Test Running } \\
\text { box turns to FALSE } \\
\text { examine the results. (The } \\
\text { test will take about } \\
20 \text { minutes to run) }\end{array}$ & $\begin{array}{l}\text { Verify that the test runs and that for each Point } \\
\text { Processing Breakdown that the following criteria } \\
\text { are met. } \\
\text { for Update Pt. the } \% \text { CPU per points } / \mathrm{sec}<0.28 \\
\text { for Alarm Check the } \% \text { CPU per points } / \mathrm{sec}<0.07 \\
\text { for Log to Disk the } \% \text { CPU per points } / \mathrm{sec}<0.57\end{array}$ & \\
\hline 3. & $\begin{array}{l}\text { Click on the "Print" } \\
\text { button. }\end{array}$ & $\begin{array}{l}\text { Verify that the workspace prints. } \\
\text { Attach the printout to this test procedure. }\end{array}$ & \\
\hline 4. & $\begin{array}{l}\text { Hide the Performance } \\
\text { Test workspace }\end{array}$ & Verify the workspace is hidden. & \\
\hline
\end{tabular}

\subsection{SERVICE REQUESTS}

\subsubsection{SR 6 - Do Not Allow Duplicate Readings From TMACS To Be Inserted Into SACS}

\begin{tabular}{|c|c|c|c|}
\hline Step & Perform & Expected Result & Initial \\
\hline 1. & $\begin{array}{l}\text { Run a MS-SQL query to } \\
\text { determine how many } \\
\text { TMACS (Surface and } \\
\text { Temperature) readings } \\
\text { were inserted into the } \\
\text { SACS systems for the } \\
\text { previous night. }\end{array}$ & $\begin{array}{l}\text { Write down the number of readings } \\
\text { Temperature } \\
\text { Surface Level }\end{array}$ & \\
\hline 2. & $\begin{array}{l}\text { Move the previous night } \\
\text { SACS input files (DST and } \\
\text { SST files ) from } \\
\text { TMACSPROD to the } \\
\text { appropriate place on TFS } \\
9 . \\
\text { What until the files have } \\
\text { been processed. }\end{array}$ & Verify that the reading count is the same. & \\
\hline
\end{tabular}


HNF-3967, Rev. 3

\begin{tabular}{|c|l|c|c|}
\hline Step & \multicolumn{1}{|c|}{ Perform } & Expected Result & Initial \\
\hline $\begin{array}{l}\text { Re-run the MS Query in } \\
\text { step 1 }\end{array}$ & & \\
\hline
\end{tabular}

6.9.2 52 - Add "Point Processing" And "Alarm Processing" Features To Panalarm Sensors

This service request is completed upon successful completion of section 6.5.4.

\subsubsection{SR 86 - Add SACS Level Sensors For Each Tank That Has A ENRAF}

\begin{tabular}{|l|l|l|c|}
\hline Step & \multicolumn{1}{|c|}{ Perform } & \multicolumn{1}{c|}{ Expected Result } & Initial \\
\hline 1. & $\begin{array}{l}\text { Run an Inspect command } \\
\text { that displays the tanks that } \\
\text { has an ENRAF level sensor } \\
\text { and not a SAC_LEVEL } \\
\text { sensor. }\end{array}$ & Verify no tanks are displayed. & \\
\hline
\end{tabular}

\subsubsection{SR 112 - Add Feature To Record Hourly G2 Performance Data}

\begin{tabular}{|l|l|l|l|}
\hline Step & \multicolumn{1}{|c|}{ Perform } & \multicolumn{1}{|c|}{ Expected Result } & Initial \\
\hline 1. & $\begin{array}{l}\text { Display the Performance } \\
\text { data file. } \\
\text { perf_data_yyyy_mmdd.dat }\end{array}$ & $\begin{array}{l}\text { Verify hourly performance data is being } \\
\text { recorded. }\end{array}$ & \\
& where & & \\
$Y=$ year & & \\
& $M=$ month & & \\
& $D=$ day & & \\
\hline
\end{tabular}

6.9.5 156 - Remove Sensors Associated With The Temperature And Pressure Transmitter On Tank C-106 Riser 7

\begin{tabular}{|c|c|c|c|}
\hline Step & Perform & Expected Result & Initial \\
\hline 1. & $\begin{array}{l}\text { Run an Inspect command } \\
\text { to display the continuous } \\
\text { sensors for Tank C-106. }\end{array}$ & $\begin{array}{l}\text { Verify that the following sensors are not } \\
\text { displayed. } \\
\text { - C106-TI-R007-01 } \\
\text { - C106-TI-U2-RJA } \\
\text { - C106-TI-U2-RJB } \\
\text { - C106-PDI-R7-1306A } \\
\text { - C106-PDI-R7-1306B }\end{array}$ & \\
\hline
\end{tabular}




\subsubsection{SR 159 - Modify The Source Of BX-106 Enraf Level To Be From A CIU Instead Of An Acromag}

\begin{tabular}{|l|l|l|l|}
\hline Step & \multicolumn{1}{|c|}{ Perform } & \multicolumn{1}{|c|}{ Expected Result } & Initial \\
\hline 1. & $\begin{array}{l}\text { Displayed the sensor } \\
\text { details for BX-106 Enraf. }\end{array}$ & $\begin{array}{l}\text { Verify the following: } \\
\bullet \quad \text { Tag Name is BX106-LI-R008-01A } \\
-\quad \text { Data source is an ENRAF CIU }\end{array}$ & \\
\hline
\end{tabular}

\subsubsection{SR 160 - Sensor Configuration Changes For Tanks TX-102 And TX-104}

\begin{tabular}{|c|c|c|c|}
\hline Step & Perform & Expected Result & Initial \\
\hline 1. & $\begin{array}{l}\text { Display the tank workspace } \\
\text { for Tank TX-102. }\end{array}$ & $\begin{array}{l}\text { Verify that the thermocouple sensor for TC- } 01 \text { is } \\
\text { displayed on the workspace in the appropriate } \\
\text { position. }\end{array}$ & \\
\hline 2. & $\begin{array}{l}\text { Display the tank workspace } \\
\text { for Tank TX-104. }\end{array}$ & $\begin{array}{l}\text { Verify that the thermocouple sensor for TC- } 01 \text { is } \\
\text { displayed on the workspace in the appropriate } \\
\text { position. }\end{array}$ & \\
\hline 3. & $\begin{array}{l}\text { Display the sensor details } \\
\text { for sensor TX113-TI- } \\
\text { R008-13 }\end{array}$ & $\begin{array}{l}\text { Verify the data source for the sensor is from } \\
\text { ANA-STA-04-039. }\end{array}$ & \\
\hline
\end{tabular}

\subsubsection{SR 165 - Eliminate Multiple Instances Of SYM-AN101-TI-RO4A-36}

\begin{tabular}{|l|l|l|c|}
\hline Step & \multicolumn{1}{|c|}{ Perform } & \multicolumn{1}{|c|}{ Expected Result } & Initial \\
\hline 1. & $\begin{array}{l}\text { Run an Inspect command } \\
\text { that displays the number of } \\
\text { instances of an object } \\
\text { labeled SYM-AN101-TI- } \\
\text { R04A-36. }\end{array}$ & Verify there is only one. & \\
\hline
\end{tabular}

\subsubsection{SR 175 - Correct AN105 SHMS Input Channels To Be 9,10,11}

\begin{tabular}{|l|l|l|c|}
\hline Step & \multicolumn{1}{|c|}{ Perform } & \multicolumn{1}{c|}{ Expected Result } & Initial \\
\hline 1. & $\begin{array}{l}\text { Displayed the sensor } \\
\text { details for the following } \\
\text { Tank AN105 SHMS } \\
\text { sensors: }\end{array}$ & $\begin{array}{l}\text { Verify that the sensors are configured for } \\
\text { Acromag Station ANA-STA-01-04-069 on the } \\
\text { following channels: }\end{array}$ & \\
& $\begin{array}{l}\text { AN105-NI-VTP-154K } \\
\text { AN105-NI-VTP-155K } \\
\text { AN105-NI-VTP-154K - Channel 9 }\end{array}$ & \\
& $\begin{array}{l}\text { AN105-NI-VTP-155K - Channel 10 } \\
\text { AN105-NI-VTP-157K - Channel 11 }\end{array}$ & \\
\hline
\end{tabular}




\subsubsection{SR 179 - Correct Auto Restart Of Acromag Drivers When Connection Is Lost}

\begin{tabular}{|l|l|l|l|}
\hline Step & \multicolumn{1}{|c|}{ Perform } & \multicolumn{1}{|c|}{ Expected Result } & Initial \\
\hline 1. & $\begin{array}{l}\text { Stop the one or more of the } \\
\text { Acromag services. }\end{array}$ & $\begin{array}{l}\text { Verify the TMACS system automatically restarts } \\
\text { the service. }\end{array}$ & \\
\hline
\end{tabular}

\subsubsection{SR 417 - Set Default Reference Termomcouple Limits}

\begin{tabular}{|c|c|c|c|}
\hline Step & Perform & Expected Result & Initial \\
\hline 1. & $\begin{array}{l}\text { Run an Inspect command that } \\
\text { displays the reference couple } \\
\text { thermocouples that do not meet the } \\
\text { following criteria: } \\
\text { - } \\
\text { - Alarm Low Limit }=-20 \mathrm{~F} \\
\text { - } \\
\text { Low Instrument Limit }=16.6 \mathrm{~F}\end{array}$ & $\begin{array}{l}\text { Verify there are no reference } \\
\text { thermocouples that do not meet the } \\
\text { criteria. }\end{array}$ & \\
\hline
\end{tabular}

\subsubsection{SR 422 - Correct Start-Up Error Msg Problem}

This service request is completed upon successful completion of section 6.1.1 "Startup".

\subsubsection{SR 424 - Add SACS Surface Level To All Monitored Tanks}

\begin{tabular}{|l|l|l|l|}
\hline Step & \multicolumn{1}{|c|}{ Perform } & \multicolumn{1}{c|}{ Expected Result } & Initial \\
\hline 1. & $\begin{array}{l}\text { Run an Inspect command } \\
\text { that displays the monitored } \\
\text { tanks that do not have a } \\
\text { SACS surface level } \\
\text { configured. }\end{array}$ & Verify that there are no tanks displayed. & \\
\hline
\end{tabular}

\subsubsection{SR 426 - Add Disabled Sensors To SENSOR CONFIGURATION Report}

\begin{tabular}{|l|l|l|l|}
\hline Step & \multicolumn{1}{|c|}{ Perform } & \multicolumn{1}{|c|}{ Expected Result } & Initial \\
\hline 1. & $\begin{array}{l}\text { Run the SENSOR } \\
\text { PARAMETER } \\
\text { CONFIGURATION report. }\end{array}$ & $\begin{array}{l}\text { Verify that the sensors are displayed on the } \\
\text { report. } \\
\text { Select a few disabled sensors at } \\
\text { random. }\end{array}$ & \\
\hline
\end{tabular}




\subsubsection{SR 428 - Correct errors with AY and AZ Annotation Arrays}

\begin{tabular}{|l|l|l|l|}
\hline Step & \multicolumn{1}{|c|}{ Perform } & \multicolumn{1}{c|}{ Expected Result } & Initial \\
\hline 1. & \multicolumn{1}{|c|}{} & \\
\hline 2. & $\begin{array}{l}\text { Display the Annotation } \\
\text { Arrays for AY /AZ } \\
\text { Exhauster discrete sensors. }\end{array}$ & $\begin{array}{l}\text { Verify the arrays are configured correctly and do } \\
\text { not have an initialization value of } 9999 .\end{array}$ & \\
\hline
\end{tabular}

\subsubsection{SR 474 - Add ENRAF To Tank T110}

\begin{tabular}{|l|l|l|c|}
\hline Step & \multicolumn{1}{|c|}{ Perform } & \multicolumn{1}{|c|}{ Expected Result } & Initial \\
\hline 1. & $\begin{array}{l}\text { Display tank T110 } \\
\text { workspace }\end{array}$ & Verify there is an ENRAF sensor configured. & \\
\hline
\end{tabular}

\subsubsection{SR 573 - Correct Configuration Of C106 ENRAF To Point To Riser 1}

\begin{tabular}{|l|l|l|l|}
\hline Step & \multicolumn{1}{|c|}{ Perform } & Expected Result & Initial \\
\hline 1. & $\begin{array}{l}\text { Display the sensor details } \\
\text { for ENARF in tank C106. }\end{array}$ & Verify the tag name is C106-LI-R001-01. & \\
\hline
\end{tabular}

\subsubsection{SR 721 - Rename Serial Ports From COM To DIGI}

\begin{tabular}{|l|l|l|c|}
\hline Step & \multicolumn{1}{|c|}{ Perform } & \multicolumn{1}{c|}{ Expected Result } & Initial \\
\hline 1. & $\begin{array}{l}\text { Display the serial port } \\
\text { names associated with the } \\
\text { Digi multi port I/O box. }\end{array}$ & $\begin{array}{l}\text { Verify the name convention is DIGI_X where X } \\
\text { is the number of the port on the Digi multi port } \\
\text { I/O box. }\end{array}$ & \\
\hline
\end{tabular}

\subsubsection{SR 747 - Move ENRAFS in Tanks A101, A103 and A106 to AW CIU}

\begin{tabular}{|l|l|l|l|}
\hline Step & \multicolumn{1}{|c|}{ Perform } & \multicolumn{1}{|c|}{ Expected Result } & Initial \\
\hline 1. & $\begin{array}{l}\text { Display the sensor details } \\
\text { for Tank A101. }\end{array}$ & $\begin{array}{l}\text { Verify the sensor is report through the following: } \\
\text { ENRAF-STA-06-01-01-61 }\end{array}$ & \\
\hline 2. & $\begin{array}{l}\text { Display the sensor details } \\
\text { for Tank A103. }\end{array}$ & $\begin{array}{l}\text { Verify the sensor is report through the following: } \\
\text { ENRAF-STA-06-01-01-62 }\end{array}$ & \\
\hline 3. & $\begin{array}{l}\text { Display the sensor details } \\
\text { for Tank A106. }\end{array}$ & Verify the sensor is report through the following: & \\
\hline
\end{tabular}


HNF-3967, Rev. 3

\begin{tabular}{|r|r|l|l|}
\hline Step & Perform & Expected Result & Initial \\
\hline & & ENRAF-STA-06-01-01-63 & \\
\hline
\end{tabular}

\subsubsection{SR 750 - Lengthen Acromag Timeout From 180 Ms To 500 Ms For Acromag} Connected To The Supermux

\begin{tabular}{|l|l|l|l|}
\hline Step & \multicolumn{1}{|c|}{ Perform } & \multicolumn{1}{|c|}{ Expected Result } & Initial \\
\hline 1. & $\begin{array}{l}\text { Display the remote } \\
\text { processing initialization } \\
\text { string for Acromag } \\
\text { drivers/services that } \\
\text { communicate through the } \\
\begin{array}{l}\text { SuperMux. (Acromag } \\
\text { driver/services 3-5) }\end{array}\end{array}$ & $\begin{array}{l}\text { Verify that the timeout value is to 500 } \\
\text { milliseconds. }\end{array}$ & \\
\hline
\end{tabular}

\subsubsection{SR 774 - Label SHMS Cabinets Where Multiple SHMS On Tank Workspace}

\begin{tabular}{|l|l|l|l|}
\hline Step & \multicolumn{1}{|c|}{ Perform } & \multicolumn{1}{c|}{ Expected Result } & Initial \\
\hline 1. & $\begin{array}{l}\text { Run an Inspect command } \\
\text { to display the tank } \\
\text { workspaces that contain } \\
\text { multiple SHMS cabinets. } \\
\text { Display the tank workspace } \\
\text { for each tank listed. }\end{array}$ & Verify the cabinets are labeled properly. & \\
\hline
\end{tabular}

\subsubsection{SR 789 - Set The Alarm Limits For TMACS Sensor Not Visibile To The} Opeator

\begin{tabular}{|l|l|l|l|}
\hline Step & \multicolumn{1}{|c|}{ Perform } & \multicolumn{1}{|c|}{ Expected Result } & Initial \\
\hline 1. & $\begin{array}{l}\text { Run an Inspect command } \\
\text { that displays the high and } \\
\text { low alarm limits from } \\
\text { sensors not visible to the } \\
\text { TMACS operators. }\end{array}$ & $\begin{array}{l}\text { Verify that the limits are set as follows: } \\
\text { Low Limit }-32767\end{array}$ & \\
\hline
\end{tabular}

\subsubsection{SR 812 - Add Cabability For Operators To Display The Data Graphed On The Single Sensor Trends}

This service request is completed upon successful completion of section 6.3.1.3 Operation of Sensor History. 
HNF-3967, Rev. 3

\subsubsection{SR 820-Apply SQL Service Pack 5}

\begin{tabular}{|l|l|l|c|}
\hline Step & \multicolumn{1}{|c|}{ Perform } & \multicolumn{1}{c|}{ Expected Result } & Initial \\
\hline 1. & $\begin{array}{l}\text { On the servers } \\
\text { TMACSPROD and } \\
\text { TMACSDEV run the } \\
\text { following MS SQL Query : } \\
\text { Select @@Version }\end{array}$ & $\begin{array}{l}\text { Verify that the version number 6.50.416 is } \\
\text { displayed. }\end{array}$ & \\
\hline
\end{tabular}

\subsubsection{SR 825 - Eliminate The SACS_Level Readings From The SST And DST Files}

\begin{tabular}{|c|c|c|c|}
\hline Step & Perform & Expected Result & Initial \\
\hline 2. & $\begin{array}{l}\text { Display a Single Shell } \\
\text { daily file. } \\
\text { File can be found in the } \\
\text { directory } \\
\text { F:LBackedup TMACSDatal } \\
\text { History with the file name } \\
\text { of } \\
\text { - sst_data_yyyy_mmdd__ } \\
\text { mmss.rdbms } \\
\text { where: } \\
\text { yyyy = the year } \\
\text { mm = the month } \\
\text { dd = the day } \\
\text { hh = the hour } \\
\text { mm = the minute }\end{array}$ & $\begin{array}{l}\text { Verify the SACS_LEVEL sensors are not } \\
\text { included. }\end{array}$ & \\
\hline 3. & $\begin{array}{l}\text { Display a Double Shell } \\
\text { daily file. } \\
\text { File can be found in the } \\
\text { directory } \\
\text { F: } \backslash \text { Backedup } \backslash \text { TMACSData } \\
\text { History with the file name } \\
\text { of } \\
\text { - dst_data_yyyy_mmdd_ } \\
\text { mmss.rdbms }\end{array}$ & $\begin{array}{l}\text { Verify the SACS_LEVEL sensors are not } \\
\text { included. }\end{array}$ & \\
\hline
\end{tabular}


HNF-3967, Rev. 3

\begin{tabular}{|c|c|c|c|}
\hline Step & Perform & Expected Result & Initial \\
\hline & where: & & \\
& $\begin{array}{l}\text { yyyy }=\text { the year } \\
\mathrm{mm}=\text { the month } \\
\mathrm{dd}=\text { the day } \\
\mathrm{hh}=\text { the hour } \\
\mathrm{mm}=\text { the minute }\end{array}$ & & \\
& & & \\
\hline
\end{tabular}

\subsubsection{SR 831 - Create A Report The Displays Sensors That Have Not Received A Reading Within The Last 24 Hrs}

This service request is completed upon successful completion of section 6.4.1 Suspect Sensor Report.

6.9.27 SR 832 - Create A Unknown Sensor Report. (Quality Status $=$ Unknown)

This service request is completed upon successful completion of section 6.4.3 Unknown Sensor Report.

6.9.28 SR 833 - Change Instrument Limits For Sy 101 Enraf To Match Field Conditions

\begin{tabular}{|l|l|l|l|}
\hline Step & \multicolumn{1}{|c|}{ Perform } & \multicolumn{1}{|c|}{ Expected Result } & Initial \\
\hline 1. & $\begin{array}{l}\text { Display the sensor details } \\
\text { for sensor }\end{array}$ & $\begin{array}{l}\text { Verify that the instruments limits for the sensor } \\
\text { are as follows: }\end{array}$ & \\
& & $\begin{array}{l}\text { Instrument Low }-369 \\
\text { - Instrument High - 471 }\end{array}$ & \\
\hline
\end{tabular}

6.9.29 SR 834 - Correct Path/File Name Variable Used To Save Knowledge Base Upon Successful Completion Of Engineer Control Of Alarm Limits

\begin{tabular}{|l|l|l|l|}
\hline Step & \multicolumn{1}{|c|}{ Perform } & \multicolumn{1}{c|}{ Expected Result } & Initial \\
\hline 1. & $\begin{array}{l}\text { Display the procedure } \\
\text { SURVEILLANCE- } \\
\text { UPDATE-ALARM- } \\
\text { LIMITS. }\end{array}$ & $\begin{array}{l}\text { Verify that there is a call to save the knowledge } \\
\text { base to disk is as follows: }\end{array}$ & \\
& & $\begin{array}{l}\text { ERROR }=\text { call g2-save-module("[g2-kbs- } \\
\text { dir]htff.kb", true,false, the symbol htff, false); } \\
\text { Note: Look for Print Updating KB }\end{array}$ & \\
\hline
\end{tabular}

\subsubsection{SR 837 - Correct Problem Of SST And DST File Not Created When Changing To Daylight Savings Time}


HNF-3967, Rev. 3

\begin{tabular}{|c|c|c|c|}
\hline Step & Perform & Expected Result & Initial \\
\hline 1. & $\begin{array}{l}\text { Prior to starting TMACS } \\
\text { set the date and time to at } \\
\text { least } 30 \text { minutes before } \\
\text { 2:00 AM on the date of } \\
\text { spring daylight saving time } \\
\text { (i.e. } 4 / 4 / 1999 \text { ). } \\
\text { Wait for approximately } 3-4 \\
\text { hours (until after } 4 \text { AM } \\
\text { daylight savings time) }\end{array}$ & $\begin{array}{l}\text { Verify that new SST and DST were created in } \\
\text { the directory: } \\
\text { F: } \text { Backedup } \backslash \text { TMACSDatalHistory }\end{array}$ & \\
\hline
\end{tabular}

\subsubsection{SR 839 - Shorten The Delay Time For Starting Up I/O Drivers}

\begin{tabular}{|l|l|l|l|}
\hline Step & \multicolumn{1}{|c|}{ Perform } & \multicolumn{1}{c|}{ Expected Result } & Initial \\
\hline 1. & $\begin{array}{l}\text { Run an inspect command } \\
\text { to display the delay time } \\
\text { for starting up the I/O } \\
\text { Drivers (Services) }\end{array}$ & $\begin{array}{l}\text { Verify the delay time is set to less than 5 } \\
\text { seconds. }\end{array}$ & $\begin{array}{l}\text { Select a driver/service at } \\
\text { random. }\end{array}$ \\
\hline 2. & $\begin{array}{l}\text { Verify the service is restarted automatically by } \\
\text { TMACS. }\end{array}$ & \\
\hline
\end{tabular}

\subsubsection{SR 840 - Correct Problem Of At Start-Up Where Files Are Moved To Wrong Directory of Tfs 9}

The service request can only be verified on the production system and will be tested at installation time and if any anomalies will be document on the Operational Test Procedure.

\subsubsection{SR 841 - Configure Enraf Of Tanks AP-101 Thru AP-108, S-104, Sx-107, Sx-108 And Sx-110 Thru Sx-115}

\begin{tabular}{|l|l|l|l|}
\hline Step & \multicolumn{1}{|c|}{ Perform } & \multicolumn{1}{|c|}{ Expected Result } & Initial \\
\hline 1. & $\begin{array}{l}\text { Display Tank AP-101 } \\
\text { workspace. }\end{array}$ & Verify the ENRAF for this tank is displayed. & \\
\hline 2. & $\begin{array}{l}\text { Display the sensor details } \\
\text { for the ENRAF sensor }\end{array}$ & $\begin{array}{l}\text { Verify the following: } \\
\text { data source is from an ENRAF CIU } \\
\text { sensor tag name is AP101-LI-R002-01 }\end{array}$ & $\begin{array}{l}\text { Verify the following: } \\
\text { data source is from an ENRAF CIU } \\
\text { sensor tag name is AP102-LI-R002-01 }\end{array}$ \\
\hline 3. & $\begin{array}{l}\text { Repeat steps 1 and 2 for } \\
\text { Tank AP-102 }\end{array}$ & $\begin{array}{l}\text { Verify the following: } \\
\text { data source is from an ENRAF CIU }\end{array}$ & \\
\hline 4. & $\begin{array}{l}\text { Repeat steps 1 and 2 for } \\
\text { Tank AP-103 }\end{array}$ &
\end{tabular}


HNF-3967, Rev. 3

\begin{tabular}{|c|c|c|c|}
\hline Step & Perform & Expected Result & Initial \\
\hline & & - sensor tag name is AP103-LI-R002-01 & \\
\hline 5. & $\begin{array}{l}\text { Repeat steps } 1 \text { and } 2 \text { for } \\
\text { Tank AP-104 }\end{array}$ & $\begin{array}{l}\text { Verify the following: } \\
\text { - data source is from an ENRAF CIU } \\
\text { - sensor tag name is AP104-LI-R002-01 }\end{array}$ & \\
\hline 6. & $\begin{array}{l}\text { Repeat steps } 1 \text { and } 2 \text { for } \\
\text { Tank AP-105 }\end{array}$ & $\begin{array}{l}\text { Verify the following: } \\
\text { - data source is from an ENRAF CIU } \\
\text { - sensor tag name is AP105-LI-R002-01 }\end{array}$ & \\
\hline 7. & $\begin{array}{l}\text { Repeat steps } 1 \text { and } 2 \text { for } \\
\text { Tank AP-106 }\end{array}$ & $\begin{array}{l}\text { Verify the following: } \\
\text { - data source is from an ENRAF CIU } \\
\text { - sensor tag name is AP106-LI-R002-01 }\end{array}$ & \\
\hline 8. & $\begin{array}{l}\text { Repeat steps } 1 \text { and } 2 \text { for } \\
\text { Tank AP- } 107\end{array}$ & $\begin{array}{l}\text { Verify the following: } \\
\text { - data source is from an ENRAF CIU } \\
\text { - sensor tag name is AP107-LI-R002-01 }\end{array}$ & \\
\hline 9. & $\begin{array}{l}\text { Repeat steps } 1 \text { and } 2 \text { for } \\
\text { Tank AP-108 }\end{array}$ & $\begin{array}{l}\text { Verify the following: } \\
\text { - data source is from an ENRAF CIU } \\
\text { - sensor tag name is AP108-LI-R002-01 }\end{array}$ & \\
\hline 10. & $\begin{array}{l}\text { Repeat steps } 1 \text { and } 2 \text { for } \\
\text { Tank S- } 104\end{array}$ & $\begin{array}{l}\text { Verify the following: } \\
\text { - data source is from an ENRAF CIU } \\
\text { - sensor tag name is S104-LI-R005-01 }\end{array}$ & \\
\hline 11. & $\begin{array}{l}\text { Repeat steps } 1 \text { and } 2 \text { for } \\
\text { Tank SX-107 }\end{array}$ & $\begin{array}{l}\text { Verify the following: } \\
\text { - data source is from an ENRAF CIU } \\
\text { - sensor tag name is SX107-LI-R002-01 }\end{array}$ & \\
\hline 12. & $\begin{array}{l}\text { Repeat steps } 1 \text { and } 2 \text { for } \\
\text { Tank SX-108 }\end{array}$ & $\begin{array}{l}\text { Verify the following: } \\
\text { - data source is from an ENRAF CIU } \\
\text { - sensor tag name is SX108-LI-R002-01 }\end{array}$ & \\
\hline 13. & $\begin{array}{l}\text { Repeat steps } 1 \text { and } 2 \text { for } \\
\text { Tank SX-110 }\end{array}$ & $\begin{array}{l}\text { Verify the following: } \\
\text { - data source is from an ENRAF CIU } \\
\text { - sensor tag name is SX110-LI-R002-01 }\end{array}$ & \\
\hline 14. & $\begin{array}{l}\text { Repeat steps } 1 \text { and } 2 \text { for } \\
\text { Tank SX-111 }\end{array}$ & $\begin{array}{l}\text { Verify the following: } \\
\text { - data source is from an ENRAF CIU } \\
\text { - sensor tag name is SX111-LI-R002-01 }\end{array}$ & \\
\hline 15. & $\begin{array}{l}\text { Repeat steps } 1 \text { and } 2 \text { for } \\
\text { Tank SX-112 }\end{array}$ & $\begin{array}{l}\text { Verify the following: } \\
\text { - data source is from an ENRAF CIU } \\
\text { - sensor tag name is SX112-LI-RO02-01 }\end{array}$ & \\
\hline 16. & $\begin{array}{l}\text { Repeat steps } 1 \text { and } 2 \text { for } \\
\text { Tank SX-113 }\end{array}$ & $\begin{array}{l}\text { Verify the following: } \\
\text { - data source is from an ENRAF CIU } \\
\text { - sensor tag name is SX113-LI-R002-01 }\end{array}$ & \\
\hline 17. & $\begin{array}{l}\text { Repeat steps } 1 \text { and } 2 \text { for } \\
\text { Tank SX-114 }\end{array}$ & $\begin{array}{l}\text { Verify the following: } \\
\text { - data source is from an ENRAF CIU } \\
\text { - } \quad \text { sensor tag name is SX114-LI-R002-01 }\end{array}$ & \\
\hline 18. & $\begin{array}{l}\text { Repeat steps } 1 \text { and } 2 \text { for } \\
\text { Tank SX-115 }\end{array}$ & $\begin{array}{l}\text { Verify the following: } \\
\text { - data source is from an ENRAF CIU } \\
\text { - sensor tag name is SX115-LI-R002-01 }\end{array}$ & \\
\hline
\end{tabular}


HNF-3967, Rev. 3

6.9.34 SR 843 - Configure Enrafs For Tanks S-101, S-105, S-108, S-109 And C-104

\begin{tabular}{|l|l|l|l|}
\hline Step & \multicolumn{1}{|c|}{ Perform } & \multicolumn{1}{|c|}{ Expected Result } & Initial \\
\hline 1. & $\begin{array}{l}\text { Display Tank S-101 } \\
\text { workspace. }\end{array}$ & Verify the ENRAF for this tank is displayed. & \\
\hline 2. & $\begin{array}{l}\text { Display the sensor details } \\
\text { for the ENRAF sensor }\end{array}$ & $\begin{array}{l}\text { Verify the following: } \\
\text { data source is from an ENRAF CIU } \\
\text { sensor tag name is S101-LI-R003-01 }\end{array}$ & $\begin{array}{l}\text { Verify the following: } \\
\text { data source is from an ENRAF CIU } \\
\text { Tank S-105 }\end{array}$ \\
\hline 3. & $\begin{array}{l}\text { Repensor tag name is S105-LI-R003-01 } \\
\text { Tank S-108 } 1 \text { and 2 for }\end{array}$ & $\begin{array}{l}\text { Verify the following: } \\
\text { data source is from an ENRAF CIU } \\
\text { sensor tag name is S108-LI-R003-01 }\end{array}$ & \\
\hline 5. & $\begin{array}{l}\text { Repeat steps } 1 \text { and 2 for } \\
\text { Tank S-109 }\end{array}$ & $\begin{array}{l}\text { Verify the following: } \\
\text { data source is from an ENRAF CIU } \\
\text { sensor tag name is S109-LI-R003-01 }\end{array}$ & \\
\hline 6. & $\begin{array}{l}\text { Repeat steps } 1 \text { and 2 for } \\
\text { Tank C-104 }\end{array}$ & $\begin{array}{l}\text { Verify the following: } \\
\text { data source is from an ENRAF CIU } \\
-\quad \text { sensor tag name is C104-LI-R008-01 }\end{array}$ & \\
\hline
\end{tabular}

\subsubsection{SR 845 - Create A Suspect I/O Station Report}

This service request is completed upon successful completion of section 6.4.2 Suspect IO-Station Report.

\subsubsection{SR 846 - Add Ability To Retrieve A Sensor Reading Upon Request}

This service request is completed upon successful completion of section 6.3.1.2 Operation of Sensor Details.

\subsubsection{SR 853 - Respan SX-106 ENRAF}

\begin{tabular}{|c|c|c|c|}
\hline Step & Perform & Expected Result & Initial \\
\hline 1. & $\begin{array}{l}\text { Displayed the sensor detail } \\
\text { for the following ENRAF } \\
\text { sensor in Tank SX106 }\end{array}$ & $\begin{array}{l}\text { Verify the following: } \\
\text { - Tag Name is SX106-LI-R003-01 } \\
\text { - Formula Expression is SurLev - convert- } \\
100(\mathrm{x})=\left(0.01^{*} \mathrm{x}\right) \\
\text { - Formula Parameter = surlev_convert }-100 \\
\text { (the CH16 of ANA-STA-05-015) }+72.0\end{array}$ & \\
\hline
\end{tabular}


HNF-3967, Rev. 3

\begin{tabular}{|c|c|c|c|}
\hline Step & Perform & Expected Result & Initial \\
\hline & & $\bullet \quad$ Instrument Low Limit $=71.0$ & \\
& & $\bullet \quad$ Instrument High Limit $=173.0$ & \\
\hline
\end{tabular}

6.9.38 SR 854 - Add ENRAF Annulus Leak Detectors for Tanks SY101, SY102, and SY103

\begin{tabular}{|c|c|c|c|}
\hline Step & Perform & Expected Result & Initial \\
\hline 1. & $\begin{array}{l}\text { Display Tank SY-101 } \\
\text { workspace. }\end{array}$ & $\begin{array}{l}\text { Verify the following ENRAF leak detectors for this } \\
\text { tank is displayed. } \\
\text { SY101-LDI-R09D-01 } \\
\text { SY101-LDI-R09A-01 } \\
\text { SY101-LDI-R10B-01 }\end{array}$ & \\
\hline 2. & $\begin{array}{l}\text { Display the sensor } \\
\text { details for each } \\
\text { sensor }\end{array}$ & $\begin{array}{l}\text { Verify the following: } \\
\text { - data source is from an ENRAF CIU } \\
\text { - sensor tag name is correct }\end{array}$ & \\
\hline 3. & $\begin{array}{l}\text { Display Tank SY-102 } \\
\text { workspace. }\end{array}$ & $\begin{array}{l}\text { Verify the following ENRAF leak detectors for this } \\
\text { tank is displayed. } \\
\text { SY102-LDI-R09C-01 } \\
\text { SY102-LDI-R09D-01 } \\
\text { SY102-LDI-R10A-01 }\end{array}$ & \\
\hline 4. & $\begin{array}{l}\text { Display the sensor } \\
\text { details for each } \\
\text { sensor }\end{array}$ & $\begin{array}{l}\text { Verify the following: } \\
\text { - data source is from an ENRAF CIU } \\
\text { - sensor tag name is correct }\end{array}$ & \\
\hline 5. & $\begin{array}{l}\text { Display Tank SY-103 } \\
\text { workspace. }\end{array}$ & $\begin{array}{l}\text { Verify the following ENRAF leak detectors for this } \\
\text { tank is displayed. } \\
\text { SY103-LDI-R09C-01 } \\
\text { SY103-LDI-R09D-01 } \\
\text { SY103-LDI-R10A-01 }\end{array}$ & \\
\hline 6. & $\begin{array}{l}\text { Display the sensor } \\
\text { details for each } \\
\text { sensor }\end{array}$ & $\begin{array}{l}\text { Verify the following: } \\
\text { - data source is from an ENRAF CIU } \\
\text { - sensor tag name is correct }\end{array}$ & \\
\hline
\end{tabular}




\subsubsection{SR 855 - Add ENRAF Level Detectors for Tanks SX106 and SY102}

\begin{tabular}{|c|c|c|c|}
\hline Step & Perform & Expected Result & Initial \\
\hline 1. & $\begin{array}{l}\text { Display Tank SX-106 } \\
\text { workspace. }\end{array}$ & $\begin{array}{l}\text { Verify the following ENRAF level detector for } \\
\text { this tank is displayed. } \\
\text { SX106-LI-R003-01 }\end{array}$ & \\
\hline 2. & $\begin{array}{l}\text { Display the sensor details } \\
\text { for the ENRAF sensor }\end{array}$ & $\begin{array}{l}\text { Verify the following: } \\
\text { - data source is from an ENRAF CIU } \\
\text { - } \quad \text { sensor tag name is correct }\end{array}$ & \\
\hline 3. & $\begin{array}{l}\text { Display Tank SY-102 } \\
\text { workspace. }\end{array}$ & $\begin{array}{l}\text { Verify the following ENRAF level detector for } \\
\text { this tank is displayed. } \\
\text { SY102-LI-R02A-01 }\end{array}$ & \\
\hline 4. & $\begin{array}{l}\text { Display the sensor details } \\
\text { for the ENRAF sensor }\end{array}$ & $\begin{array}{l}\text { Verify the following: } \\
\text { - data source is from an ENRAF CIU } \\
\text { - } \quad \text { sensor tag name is correct }\end{array}$ & \\
\hline
\end{tabular}

\subsection{TMACS SHUTDOWN}

\subsubsection{Telewindows ${ }^{(\mathrm{E})}$ Session}

\begin{tabular}{|c|c|c|c|}
\hline Step & Action & Verify & Initial \\
\hline 1. & $\begin{array}{l}\text { On the TMACS screen, type } \\
\text { Control-Y. }\end{array}$ & $\begin{array}{l}\text { Verify that the user mode selection } \\
\text { workspace appears on the screen. }\end{array}$ & \\
\hline 2. & $\begin{array}{l}\text { Edit the 'G2 } 2^{\infty} \text { user mode' to be } \\
\text { "shutdown" and click on the } \\
\text { END. }\end{array}$ & $\begin{array}{l}\text { Verify that a warning message } \\
\text { appears indicating that this function } \\
\text { is not available. } \\
\text { Verify the 'G2 } 2^{(0)} \text { user mode' has } \\
\text { reverted back to "t2-user". }\end{array}$ & \\
\hline
\end{tabular}

\subsubsection{Central Console}

\begin{tabular}{|l|l|l|c|}
\hline \multicolumn{1}{|c|}{ Step } & \multicolumn{1}{|c|}{ Action } & \multicolumn{1}{c|}{ Verify } & Initial \\
\hline 1. & On the TMACS screen, type Control-Y. & $\begin{array}{l}\text { Verify that the user mode } \\
\text { selection workspace } \\
\text { appears on the screen. }\end{array}$ & $\begin{array}{l}\text { Verify that G2 } \\
\text { terminates. }\end{array}$ \\
\hline 2. & $\begin{array}{l}\text { Edit the 'G2 } \\
\text { "shutdown" and click on the END. }\end{array}$ & \\
\hline
\end{tabular}


HNF-3967, Rev. 3

\begin{tabular}{|c|c|c|c|}
\hline Step & Action & Verify & Initial \\
\hline 3. & $\begin{array}{l}\text { As part of the shutdown process } \\
\text { TMACS creates the following files in } \\
\text { the directory } \\
\text { F:IBackedUpITMACSIDatalCurrent: } \\
\text { - Continuous_Shutdown_History_ } \\
\text { YYYY_MMDD.ascii. } \\
\text { - Discrete_Shutdown_History_ } \\
\text { YYYY_MMDD.ascii. } \\
\text { Where: } \\
\text { YYYY - is the year that the file was } \\
\text { created. } \\
\text { MM - is the month that the file was } \\
\text { created. } \\
\text { DD - is the day that the file was created. }\end{array}$ & $\begin{array}{l}\text { Verify that the files were } \\
\text { created and the format } \\
\text { match the description } \\
\text { given in the LMSI } \\
\text { External Letter, } \\
\text { RGG-SDI-99-001, } \\
\text { TMACS Data File } \\
\text { Formats, Release 11.0. }\end{array}$ & \\
\hline
\end{tabular}


HNF-3967, Rev. 3

\section{EXCEPTION SHEETS}

The following page is an example of the form used to describe exceptions found during the running of this Acceptance Test Procedure. If exceptions are found, copies of this sheet should be completed and included in the Acceptance Test Report. 
HNF-3967, Rev. 3

\section{Acceptance Test Procedure \\ Exception Record}

\begin{tabular}{|l|l|l|}
\hline Exception No. & Step No. & Date \\
\hline Originator/Organization & & \\
\hline Description: & & \\
& & \\
& & \\
& & \\
\hline Resolution: & & \\
\hline & & \\
\hline QA & & \\
\hline SSH & & \\
\hline & & \\
\hline & & \\
\hline
\end{tabular}


HNF-3967, Rev. 3

\section{PARTICIPATION RECORD SHEET}

The following page is the form used to record the participants involved in the running of this Acceptance Test Procedure. This sheet should be completed and included in the Acceptance Test Report. 
HNF-3967, Rev. 3

\section{Acceptance Test Procedure \\ Participation Record}

TEST DIRECTOR

TEST PERFORMANCE GROUP

TEST WITNESS 
HNF-3967, Rev. 3

\section{ACCEPTANCE RECORD SHEET}

The following page is the form used record the participants involved in the running of this Acceptance Test Procedure. This sheet should be completed and included in the Acceptance Test Report. 
HNF-3967, Rev. 3

\section{Acceptance Test Procedure Acceptance Record}

\section{CERTIFICATION OF SATISFACTORY EXECUTION}

All of the test cases for this test procedure have been tested and all exceptions for this test procedure have been resolved.

Test Director

Cognizant Engineer

Quality Assurance

Safety

Environmental Health 